Prepared in cooperation with the Georgia Environmental Protection Division

\title{
Hydrology of the Claiborne Aquifer and Interconnection With the Upper Floridan Aquifer in Southwest Georgia
}

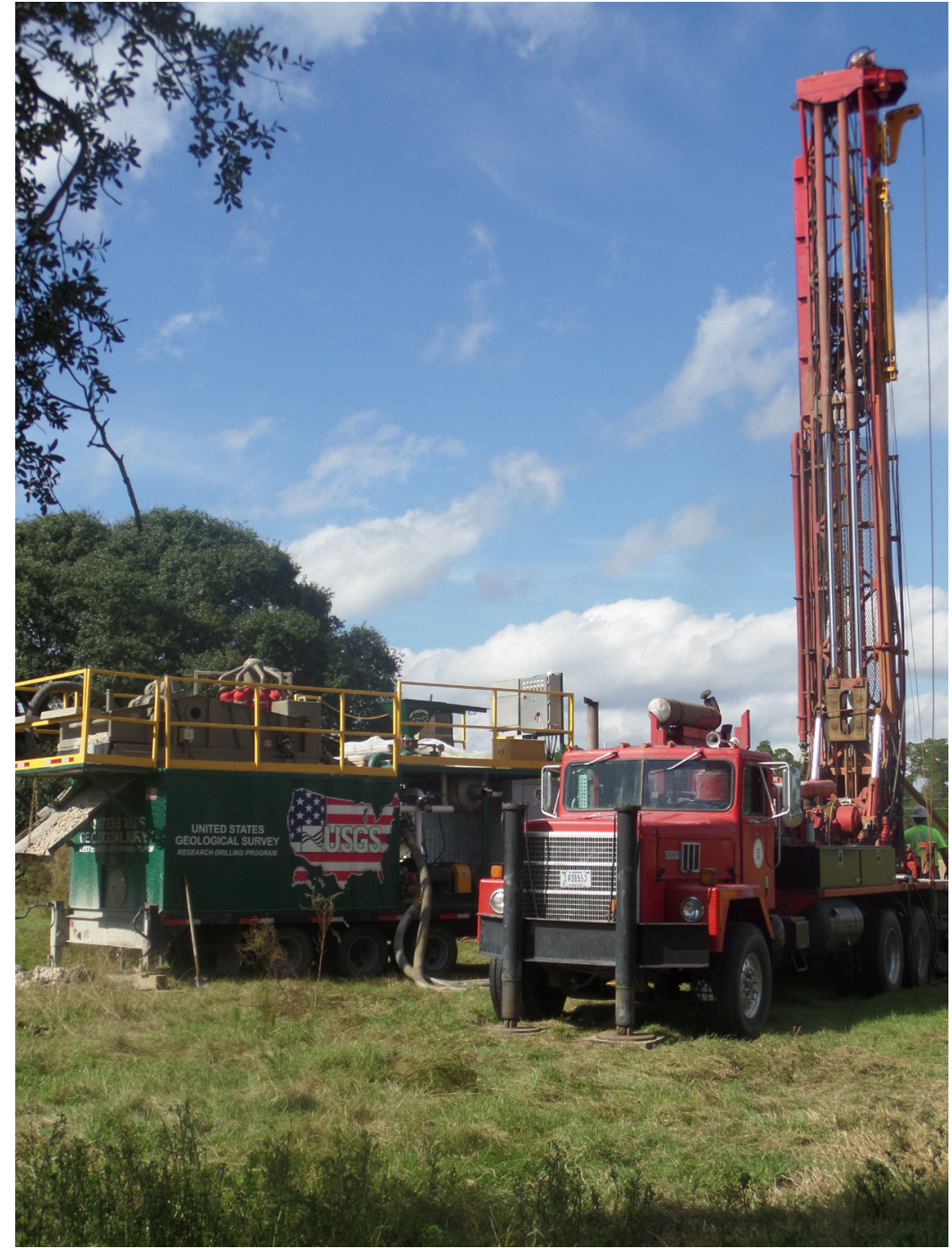

Scientific Investigations Report 2017-5017 
Cover. U.S. Geological Survey Research Drilling Program drill rig. Photograph by Debbie W. Gordon, U.S. Geological Survey. 


\section{Hydrology of the Claiborne Aquifer and Interconnection With the Upper Floridan Aquifer in Southwest Georgia}

By Debbie W. Gordon and Gerard Gonthier

Prepared in cooperation with the Georgia Environmental Protection Division

Scientific Investigations Report 2017-5017 


\title{
U.S. Department of the Interior \\ RYAN K. ZINKE, Secretary
}

\section{U.S. Geological Survey \\ Williams H. Werkheiser, Acting Director}

\author{
U.S. Geological Survey, Reston, Virginia: 2017
}

For more information on the USGS - the Federal source for science about the Earth, its natural and living resources, natural hazards, and the environment-visit https://www.usgs.gov or call 1-888-ASK-USGS.

For an overview of USGS information products, including maps, imagery, and publications,

visit https://store.usgs.gov/..

Any use of trade, firm, or product names is for descriptive purposes only and does not imply endorsement by the U.S. Government.

Although this information product, for the most part, is in the public domain, it also may contain copyrighted materials as noted in the text. Permission to reproduce copyrighted items must be secured from the copyright owner.

Suggested citation:

Gordon, D.W., and Gonthier, Gerard, 2017, Hydrology of the Claiborne aquifer and interconnection with the Upper Floridan aquifer in southwest Georgia: U.S. Geological Survey Scientific Investigations Report 2017-5017, 49 p., https://doi.org/10.3133/sir20175017.

ISSN 2328-0328 (online) 


\section{Acknowledgments}

The authors wish to thank the many landowners who allowed access to their property so that data could be collected for this report. Thanks is also extended to many others who contributed to the success of this project. Calvin Perry with the University of Georgia Stripling Irrigation Research Park provided much assistance including facilitating access to the site, activating pumps, and laying pipe to handle discharge water. Michael Hamrick, Gary Holloway, and Michael Peck of the U.S. Geological Survey assisted with site selection, borehole-geophysical logging, and aquifer testing; and helped to ensure that new well installation ran smoothly. The U.S. Geological Survey Research Drilling Program installed new wells for the aquifer tests. Laura Gurley and Caryl Wipperfurth of the U.S. Geological Survey assisted with figure and table production. 



\section{Contents}

Acknowledgments ...............................................................................................................................

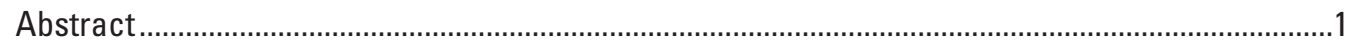

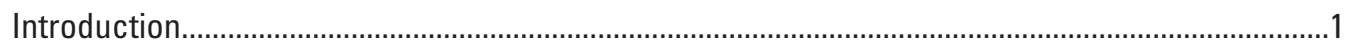

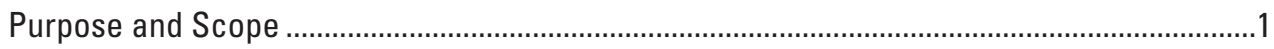

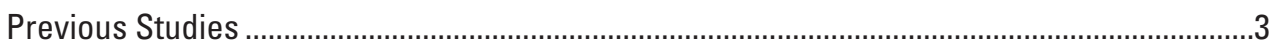

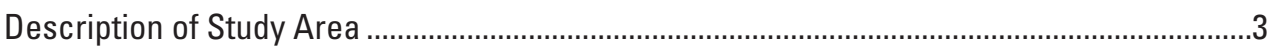

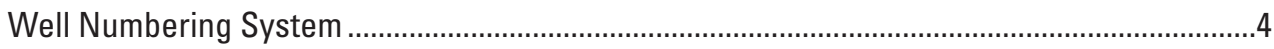

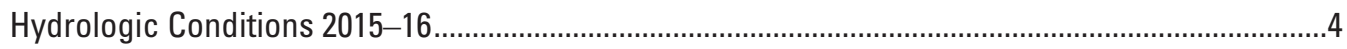

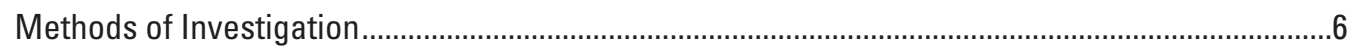

Compilation of Existing Data ............................................................................................

Borehole Geophysical Logging .........................................................................................

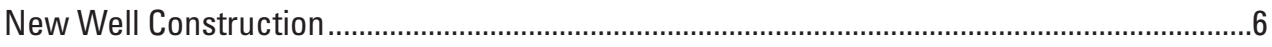

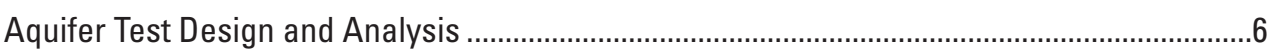

Water-Level Measurements .....................................................................................

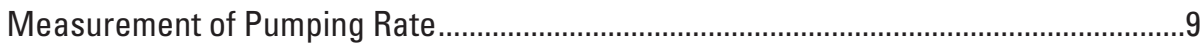

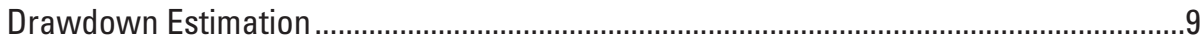

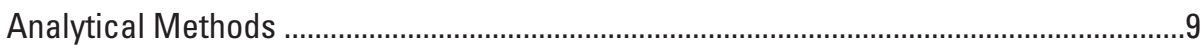

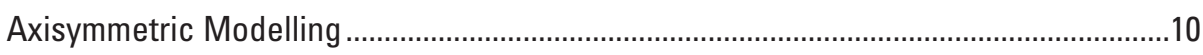

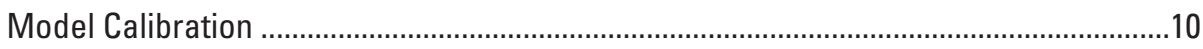

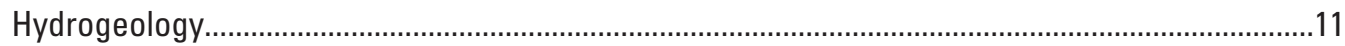

Claiborne Aquifer Hydrology and Interconnection With the Upper Floridan Aquifer ......................11

Stripling Aquifer Test.................................................................................................... 13

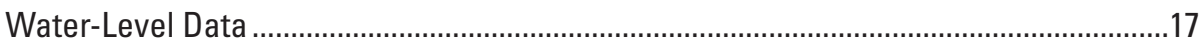

Water-Level Response to Pumping and Drawdown ......................................................17

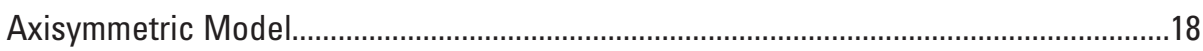

Aquifer Hydraulic Properties .................................................................................22

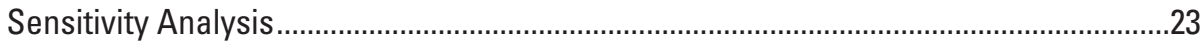

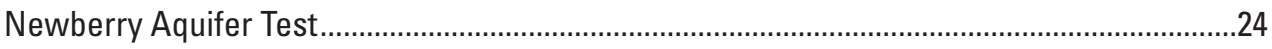

Water-Level Response to Pumping and Drawdown ........................................................30

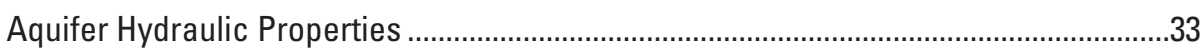

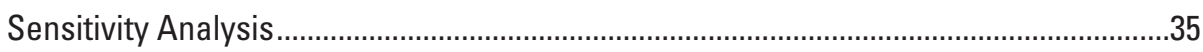

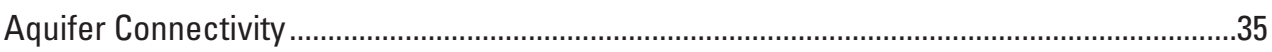

Areal Distribution of Claiborne Aquifer Hydrologic Properties ...............................................38

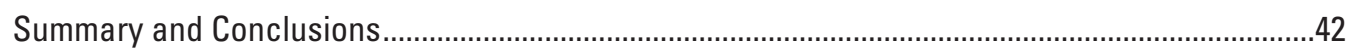

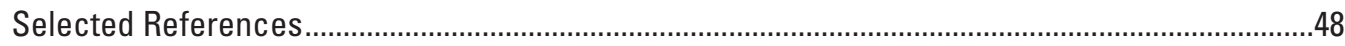




\section{Figures}

1. Map showing location of the study area and select wells in southwestern Georgia ......2

2. Chart showing generalized stratigraphy and hydrologic units underlying Albany and surrounding areas, southwestern Georgia.

3. Hydrographs of wells 12K014 in the Upper Floridan aquifer and 11J011 in the Claiborne aquifer in southwest Georgia, June 2015 through May 2016

4. Cross section showing well construction, and photograph showing aquifer test layout, Stripling Research site, northwest of Camilla, Georgia, December 15-18, 2015

5. Diagram showing hydrogeologic units, borehole geophysical logs in Claiborne aquifer monitoring well 11J025, and values of horizontal hydraulic conductivity assigned to layers of the axisymmetric model, 72-hour aquifer test, Stripling research site, near Camilla, Georgia, December 15-18, 2015.

6. Diagram showing hydrogeologic units, borehole geophysical logs in Claiborne aquifer monitoring well $08 \mathrm{~K} 025$, and values of horizontal hydraulic conductivity assigned to layers of the axisymmetric model, 72-hour aquifer test, Newberry site, northeast Early County, southeast of Arlington, Georgia, March 14-17, 2016.

7. Hydrogeologic cross-sections $A-A^{\prime}$ and $B-B^{\prime}$

8. Maps showing aerial extent of the top and base of the Claiborne aquifer in southwest Georgia

9. Map showing the thickness of the Claiborne aquifer in southwest Georgia 16

10. Graph showing water-level altitude of Claiborne aquifer wells 11J025 and 11J029 in response to aquifer-test pumping, Stripling Research site northwest of Camilla, Georgia, December 2015

11. Graph showing drawdown observations (total and selected) in Claiborne pumped well 11J029, Stripling Research site, northwest of Camilla, Georgia, December 15-21, 2015

12. Graph showing drawdown observations (total and selected) in Claiborne monitoring well 11J025, Stripling Research site, northwest of Camilla, Georgia, December 15-21, 2015

13. Log-log plot of time versus drawdown compared to the Theis curve, and semi-log plots showing semi-log drawdown and semi-log slope of drawdown of Claiborne aquifer monitoring well 11J025 compared to Papadopulos-Cooper and Walton curves.

14. Diagram showing axisymmetric model for 72 -hour aquifer test at Claiborne well 11J029, Stripling site, northwest of Camilla, Georgia, December 15-18, 2015

15. Graphs showing comparison of simulated and observed drawdown for calibrated two-dimensional, axisymmetric, radial, transient, groundwater-flow model of 72-hour aquifer test at two Claiborne aquifer wells, Stripling Research site, northwest of Camilla, Georgia, December 15-21, 2015.

16. Graphs showing root mean square of the difference between simulated and observed drawdown in Claiborne aquifer monitoring well 11J025, for different values of Claiborne aquifer transmissivity and vertical hydraulic conductivity of the confining unit between the Clayton and Claiborne aquifers, Stripling Research site aquifer test, December 15-21, 2015. 
17. Graph showing root mean square of the difference between simulated and observed drawdown for different values of specific storage in the confined groundwater system, Claiborne aquifer monitoring well 11J025, Stripling Research site aquifer test, December 15-21, 2015.

18. Graph showing root mean square of the difference between simulated and observed drawdown in Upper Floridan monitoring well 11J030, for different values of horizontal hydraulic conductivity in the Upper Floridan aquifer, Stripling Research site aquifer test, December 15-21, 2015.

19. Graphs showing root mean square of the difference between simulated and observed drawdown for different values of horizontal hydraulic conductivity in the Upper Floridan aquifer and vertical hydraulic conductivity in the Lisbon confining unit, Stripling Research site aquifer test, December 15-21, 2015

20. Cross section and aerial photograph showing well construction and layout used in a 72-hour aquifer test, Newberry site, northeast Early County, southeast of Arlington, Georgia, December 15-18, 2015.

21. Graphs showing water-level altitude and background line, Claiborne aquifer monitoring well 08K025, Newberry site, northeast Early County, southeast of Arlington, Georgia, December 30, 2015 - April 4, 2016.

22. Graphs showing water-level altitude and background line, Claiborne aquifer pumped well 08K026, Newberry site, northeast Early County, southeast of Arlington, Georgia, December 30, 2015 - April 4, 2016.

23. Graphs showing long-term drawdown response in Claiborne monitoring well 08K025 to multiple pumping events, Newberry site, northeast Early County, southeast of Arlington, Georgia, December 30, 2015 - April 4, 2016.

24. Graphs showing long-term drawdown response in Claiborne pumped well $08 \mathrm{~K} 026$ to multiple pumping events, Newberry site, northeast Early County, southeast of Arlington, Georgia, December 30, 2015 - April 4, 2016.

25. Graph showing example of estimating drawdown response to 72-hour aquifer test using simulated, long-term drawdown trend, Claiborne aquifer monitoring well 08K025, Newberry site, northeast Early County, southeast of Arlington, Georgia, March 9-28, 2016.

26. Graphs showing observed and simulated water-level altitude at Upper Floridan aquifer state-wide network well 08K001, Newberry site, northeast Early County, southeast of Arlington, Georgia

27. Graphs showing drawdown observations (total and selected) in Claiborne aquifer pumped well 08K026 in response to the 72-hour aquifer test, Newberry site, northeast Early County, southeast of Arlington, Georgia....

28. Graph showing drawdown observations (total and selected) in Claiborne aquifer monitoring well $08 \mathrm{~K} 025$ in response to the 72-hour aquifer test, Newberry site, northeast Early County, southeast of Arlington, Georgia, March 14-30, 2016

29. Semi-log plots of time versus drawdown and slope of drawdown in Claiborne aquifer pumped well 08K026 and select Papadopulos-Cooper curves.

30. Log-log plot of time versus drawdown data and the Theis curve; and semi-log slope of drawdown in Claiborne aquifer monitoring well 08K025

31. Graphs showing comparison of simulated and observed drawdown from a 72-hour aquifer test at Claiborne aquifer wells, Newberry site, northeast Early County, southeast of Arlington, Georgia, March 14-24, 2016, for pumped well $08 \mathrm{~K} 026$ and monitoring well $08 \mathrm{~K} 025$ 
32. Graphs showing simulated and observed drawdown using Theis drawdown and superposition during three pumping events at Claiborne aquifer pumped well 08K026, Newberry site, northeast Early County, southeast Arlington, Georgia

33. Graphs showing comparison of simulated and observed drawdown using Theis drawdown and superposition on three pumping events at Claiborne aquifer monitoring well 08K025, Newberry site, northeast Early County, southeast Arlington, Georgia

34. Graphs showing root mean of the square of the sum of the difference between simulated and observed drawdown in response to the 72-hour aquifer test divided by maximum drawdown, for different values of transmissivity and storage coefficient for both Claiborne wells 08K026 and 08K025, Newberry site, northeast Early County, southeast of Arlington, Georgia, March 14-20, 2016

35. Graph showing linear regression of transmissivity values estimated from specific capacity data and transmissivity calculated from aquifer test data.

36. Map showing distribution of transmissivity of the Claiborne aquifer in southwestern Georgia

\section{Tables}

1. Well construction data for selected wells in the study area, southwestern Georgia ......7

2. Well information for wells used to monitor the 72-hour aquifer test, Stripling site, northwest of Camilla, Georgia, December 15-18, 2015

3. Values of hydraulic parameters used to calibrate the model for the 72-hour aquifer test, Stripling research site, northwest of Camilla, Georgia, December 15-21, 2015.....23

4. Summary of 72-hour aquifer test results, Stripling research site, northwest of Camilla, Georgia, December 15-18, 2015.

5. Well construction information for wells used to monitor the 72-hour aquifer test, Newberry site, northeast Early County, southeast of Arlington, Georgia, December 15-18, 2015

6. Summary of 72-hour aquifer-test results, Claiborne aquifer, Newberry site, northeast Early County, southeast of Arlington, Georgia, March 14-17, 2016

7. Values of transmissivity estimated from specific capacity and transmissivity calculated from aquifer test data in the Claiborne aquifer in southwestern, Georgia ...46 


\section{Conversion Factors}

U.S. customary units to International System of Units

\begin{tabular}{lcl}
\hline \multicolumn{1}{c}{ Multiply } & By & \multicolumn{1}{c}{ To obtain } \\
\hline inch (in.) & Length & \\
inch (in.) & $2.54 \times 10^{4}$ & micrometer $(\mu \mathrm{m})$ \\
inch (in.) & 2.54 & centimeter $(\mathrm{cm})$ \\
foot (ft) & 25.4 & millimeter $(\mathrm{mm})$ \\
mile (mi) & 0.3048 & meter $(\mathrm{m})$ \\
\hline & 1.609 & kilometer $(\mathrm{km})$ \\
\hline foot per day (ft/d) & Recharge & \\
\hline & 0.3048 & meter per day $(\mathrm{m} / \mathrm{d})$ \\
\hline gallon per minute $(\mathrm{gal} / \mathrm{min})$ & Flow rate & \\
gallon per day (gal/d) & 0.06309 & liter per second $(\mathrm{L} / \mathrm{s})$ \\
\hline & 0.003785 & cubic meter per day $\left(\mathrm{m}^{3} / \mathrm{d}\right)$ \\
\hline foot squared per day $(\mathrm{ft} / \mathrm{d})$ & Transmissivity* & \\
\hline & 0.09290 & meter squared $\mathrm{per} \mathrm{day}\left(\mathrm{m}^{2} / \mathrm{d}\right)$ \\
\hline inverse foot $(1 / \mathrm{ft})$ & Specific storage & \\
\hline
\end{tabular}

Temperature in degrees Celsius $\left({ }^{\circ} \mathrm{C}\right)$ may be converted to degrees Fahrenheit $\left({ }^{\circ} \mathrm{F}\right)$ as follows:

$$
{ }^{\circ} \mathrm{F}=\left(1.8 \times{ }^{\circ} \mathrm{C}\right)+32 .
$$

Temperature in degrees Fahrenheit $\left({ }^{\circ} \mathrm{F}\right)$ may be converted to degrees Celsius $\left({ }^{\circ} \mathrm{C}\right)$ as follows:

$$
{ }^{\circ} \mathrm{C}=\left({ }^{\circ} \mathrm{F}-32\right) / 1.8 .
$$

\section{Datum}

Vertical coordinate information is referenced to the North American Vertical Datum of 1988 (NAVD 88).

Horizontal coordinate information is referenced to the North American Datum of 1983 (NAD 83).

Altitude, as used in this report, refers to the distance above the vertical datum.

\section{Supplemental Information}

Concentrations of chemical constituents in water are given in milligrams per liter (mg/L).

*Transmissivity: The standard unit for transmissivity is cubic foot per day per square foot times foot of aquifer thickness $\left[\left(\mathrm{ft}^{3} / \mathrm{d}\right) / \mathrm{ft}^{2}\right]$. In this report, the mathematically reduced form, feet squared per day $\left(\mathrm{ft}^{2} / \mathrm{d}\right)$, is used for convenience. 


\section{Abbreviations}

GaEPD Georgia Environmental Protection Division

GGS Georgia Geologic Survey

GWSI Groundwater Site Inventory

NWIS National Water Information System

USGS U.S. Geological Survey 


\title{
Hydrology of the Claiborne Aquifer and Interconnection With the Upper Floridan Aquifer in Southwest Georgia
}

\author{
By Debbie W. Gordon and Gerard Gonthier
}

\section{Abstract}

The U.S. Geological Survey conducted a study, in cooperation with the Georgia Environmental Protection Division, to define the hydrologic properties of the Claiborne aquifer and evaluate its connection with the Upper Floridan aquifer in southwest Georgia. The effort involved collecting and compiling hydrologic data from the aquifer in subarea 4 of southwestern Georgia. Data collected for this study include borehole geophysical logs in 7 wells, and two 72-hour aquifer tests to determine aquifer properties.

The top of the Claiborne aquifer extends from an altitude of about 200 feet above the North American Vertical Datum of 1988 (NAVD 88) in Terrell County to 402 feet below NAVD 88 in Decatur County, Georgia. The base of the aquifer extends from an altitude of about 60 feet above NAVD 88 in eastern Sumter County to about 750 feet below NAVD 88 in Decatur County. Aquifer thickness ranges from about 70 feet in eastern Early County to 400 feet in Decatur County.

The transmissivity of the Claiborne aquifer, determined from two 72-hour aquifer tests, was estimated to be 1,500 and 700 feet squared per day in Mitchell and Early Counties, respectively. The storage coefficient was estimated to be 0.0006 and 0.0004 for the same sites, respectively. Aquifer test data from Mitchell County indicate a small amount of leakage occurred during the test. Groundwater-flow models suggest that the source of the leakage was the underlying Clayton aquifer, which produced about 2.5 feet of drawdown in response to pumping in the Claiborne aquifer. The vertical hydraulic conductivity of the confining unit between the Claiborne and Clayton aquifers was simulated to be about 0.02 foot per day.

Results from the 72-hour aquifer tests run for this study indicated no interconnection between the Claiborne and overlying Upper Floridan aquifers at the two test sites. Additional data are needed to monitor the effects that increased withdrawals from the Claiborne aquifer may have on future water resources.

\section{Introduction}

Southwestern Georgia is experiencing increased demand on its limited freshwater resources. During July 2012, the Georgia Environmental Protection Division (GaEPD) implemented a moratorium on certain new permit applications for groundwater withdrawals from the Upper Floridan aquifer in subarea 4 (as reported in Torak and McDowell, 1996) of southwestern Georgia and on permit applications for surfacewater pumping from the Spring Creek, Ichawaynochaway Creek, and Muckalee Creek subbasins in the Flint River Basin (fig. 1). The moratorium also applies to requests to modify existing permits to increase withdrawals or increase the number of irrigated acres.

Aquifers that underlie the Upper Floridan-including the Claiborne, Clayton, and Cretaceous aquifers - may be viable alternative sources of water. Fewer wells have been completed in these aquifers than in the shallower Upper Floridan aquifer, and there is less information about their depths or their thicknesses, water quality, and water-bearing characteristics. Since 2012, numerous wells have been constructed in the Claiborne aquifer. The U.S. Geological Survey (USGS) conducted a study, in cooperation with the GaEPD, to examine new information that these new Claiborne wells provide about the hydrogeology of the Claiborne aquifer and its interconnection with the overlying Upper Floridan aquifer. This information will add to ongoing efforts to provide a regional characterization of the geology and hydrology of the southeastern United States. In addition, the data collected will be used by the GaEPD to update groundwater-flow models to manage the water resources in southwestern Georgia. Lastly, results from this study will be useful for water users as they plan for future water demand.

\section{Purpose and Scope}

This report documents the hydrologic properties of the Claiborne aquifer and the aquifer's interconnection with the Upper Floridan aquifer at two aquifer-test sites. Hydrogeologic 


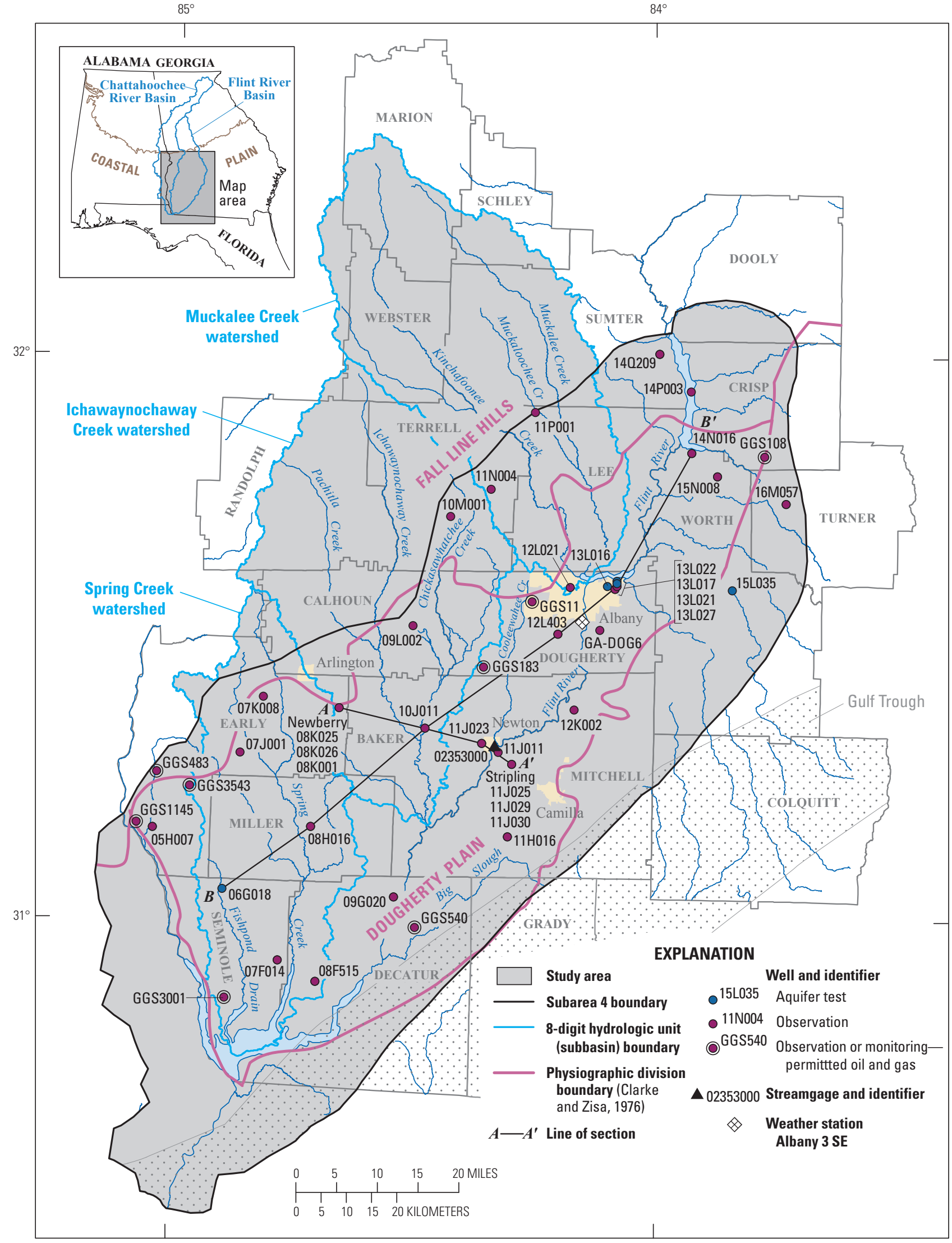

Base from U.S. Geological Survey digital files, Albers Equal-Area Conic projection, North American Datum of 1983

Figure 1. Location of the study area and select wells in southwestern Georgia. 
data were compiled and collected for the Claiborne aquifer during 2015-16.

This report presents data compiled from an existing USGS database and GaEPD files for wells in the aquifers that underlie the Upper Floridan aquifer, data collected from existing and recently constructed wells in the Claiborne aquifer, and from wells constructed for this project at two sites in the study area. The existing USGS data are available in the USGS National Water Information System database (NWIS; U.S. Geological Survey, 2016). The data compiled from GaEPD are available in the GaEPD Agricultural Unit permitting files (Edward Rooks, Georgia Environmental Protection Division, written commun., 2015, 2016). All of the new data collected during this study are available in Gordon and Gonthier (2017), including water-quality data collected from six wells; however, the water-quality data are not discussed in this report. Data described herein were obtained from the following activities:

- Borehole geophysical logs were collected and analyzed in six recently constructed and permitted Claiborneaquifer irrigation wells.

- Wells were installed at two sites so that each site had a Claiborne-aquifer production and monitoring well and an Upper Floridan aquifer monitoring well.

- A 72-hour aquifer test was performed at each of the two newly constructed well sites, and the data were analyzed to determine the hydrologic properties of the Claiborne aquifer and potential interconnection between the Upper Floridan and Claiborne aquifers.

\section{Previous Studies}

Several studies in southwestern Georgia have characterized the hydrogeology of the Clayton, Claiborne, and Cretaceous aquifers. Hicks and others (1981) evaluated the development potential of groundwater resources in the Albany, Georgia, area and reported transmissivity values that ranged from 2,400 to 3,500 feet squared per day $\left(\mathrm{ft}^{2} / \mathrm{d}\right)$, estimated from Tallahatta (Claiborne) aquifer specific capacity data. The study concluded that concentrations of calcium as high as 40 milligrams per liter $(\mathrm{mg} / \mathrm{L})$ could result from vertical leakage of water from the Upper Floridan aquifer through the Lisbon confining unit and into the Claiborne aquifer.

McFadden and Perriello (1983) compiled existing Clayton and Claiborne well data from State and Federal agencies, municipal governments, well drillers, consulting engineers, farmers, industries, and domestic-well owners. The data were used to construct potentiometric-surface maps of the Clayton and Claiborne aquifers for December 1979, October-November 1981, and March 1982. A network of over 100 observation wells was established for the study to monitor water levels. Wells were constructed for the study to test the aquifers for hydrologic properties such as transmissivity, storage coefficient, and specific capacity. Transmissivity values between 2,800 and $6,000 \mathrm{ft}^{2} / \mathrm{d}$ were reported for the Claiborne aquifer in the Albany area. The study concluded that declines in the potentiometric surface observed in the Clayton aquifer around Albany, Ga., since the 1950s would likely continue, because withdrawals from the Clayton aquifer exceeded recharge. The study also indicated that the Claiborne aquifer could sustain the amount of withdrawals occurring at that time, but that large withdrawals within a small area could cause large potentiometric declines.

Clarke and others (1984) described the hydrogeology of the Clayton aquifer in southwestern Georgia and evaluated the effects of water use on the groundwater system. They presented potentiometric-surface maps of the Clayton aquifer for 1954 and 1981, in addition to hydrogeologic sections, structure-contour maps, and thickness maps of the Clayton aquifer. Long (1989) presented an update of the available hydrologic data for the Clayton and Claiborne aquifers in southwestern Georgia. Hydrologic conditions and trends between 1981 and 1987 are described in the report.

Faye and Mayer (1997) described groundwater flow systems in five aquifers in the southeastern Coastal Plain of Georgia, including the Claiborne aquifer (which they refer to as the Tallahatta aquifer). They simulated substantial waterlevel declines for the Tallahatta-Gordon and Providence SandPeedee aquifers in the Albany area.

Kuniansky and Bellino (2012) compiled aquifer-test data for the entire Floridan aquifer system, which includes the Claiborne aquifer in southwestern Georgia. According to Williams and Kuniansky (2015, fig. 8), the Claiborne aquifer transitions into the Lower Floridan aquifer beneath the Gulf Trough. Williams and Kuniansky (2015) presented a revised hydrogeologic framework of the Floridan aquifer system. Their report includes hydrogeologic cross sections that extend through southwestern Georgia.

\section{Description of Study Area}

The study area is located in the Coastal Plain Physiographic Province in southwestern Georgia (fig. 1). The study area includes all or parts of the following southwestern Georgia counties in the lower Flint and Chattahoochee River Basins in a region known as subarea 4: Baker, Calhoun, Colquitt, Crisp, Decatur, Dooly, Dougherty, Early, Grady, Lee, Miller, Mitchell, Seminole, Sumter, Terrell, Turner and Worth. The study area also includes all or parts of Calhoun, Chattahoochee, Clay, Early, Marion, Randolph, Schley, Stewart, Sumter, Terrell and Webster Counties in the Spring Creek, Ichawaynochaway Creek, and Muckalee Creek subbasins in the Flint River Basin (Hollis, 2013).

The Fall Line Hills and Dougherty Plain compose the Coastal Plain in the study area. The Fall Line Hills, in the northern part of the study area, includes the updip limit (and recharge zone) of many of the major aquifers in the area. The 
Dougherty Plain is a flat to gently rolling karstic region, which includes internal drainage and limestone dissolution features.

The major stratigraphic units in the study area consist of Upper Cretaceous to Holocene sediments composed of sand, limestone, clay, and shale (fig. 2). The sediments dip and thicken to the southeast and were deposited on older metamorphic, igneous, and sedimentary rocks. The units, in ascending order, include the Providence Sand, the Midway Group (Clayton Formation and the Porters Creek Formation), the Wilcox Group (the Baker Hill Formation, Tuscahoma Formation, Hatchetigbee Formation), the Claiborne Group (the Tallahatta Formation and the Lisbon Formation), the Clinchfield Sand, the Ocala Limestone, and undifferentiated overburden (Clarke and others, 1984; Hicks and others, 1987).

The hydrogeologic units in the study area, in descending order, are the surficial aquifer system, the upper semiconfining unit (where present), the Upper Floridan aquifer, the Lisbon confining unit, the Claiborne aquifer (classified as part of the Lower Floridan aquifer in Williams and Dixon, 2015), the Wilcox confining unit, the Clayton aquifer, and the Providence aquifer.

In east-central Georgia, the Claiborne and Gordon aquifers, which are part of the regional Pearl River aquifer of the Southeastern Coastal Plain aquifer system (Renken, 1996), grade laterally into the lower part of the Floridan aquifer system. In Georgia, the base is identified as the Wilcox confining zone, which separates the overlying Lower Floridan and Claiborne aquifers from the underlying Clayton aquifer (Clarke and others, 1984).

\section{Well Numbering System}

Wells in Georgia are identified using a numbering system that is based on USGS topographic maps. In Georgia, each 7.5-minute topographic quadrangle map has been given a number and letter designation beginning at the southwestern corner of the State. Numbers increase eastward through 39, and letters increase alphabetically northward through "Z" and then become double-letter designations "AA" through "PP." The letters "I," "O," "II," and "OO" are not used. Wells inventoried in each quadrangle are numbered sequentially beginning with "001." Thus, the 403rd well inventoried in the Albany West quadrangle (map 12L) is designated 12L403.

Permitted oil and gas wells were denoted with a "GGS" prefix, followed by the number assigned by the Georgia Geologic Survey (GGS3114, for example). A few oil and gas test wells in Georgia that do not have an assigned GGS number were denoted with a "DP" prefix followed by the Georgia Environmental Protection Division permit number.

\section{Hydrologic Conditions 2015-16}

Camilla and Arlington, Ga., both receive about 51 inches (in.) of rainfall during a typical year (University of Georgia

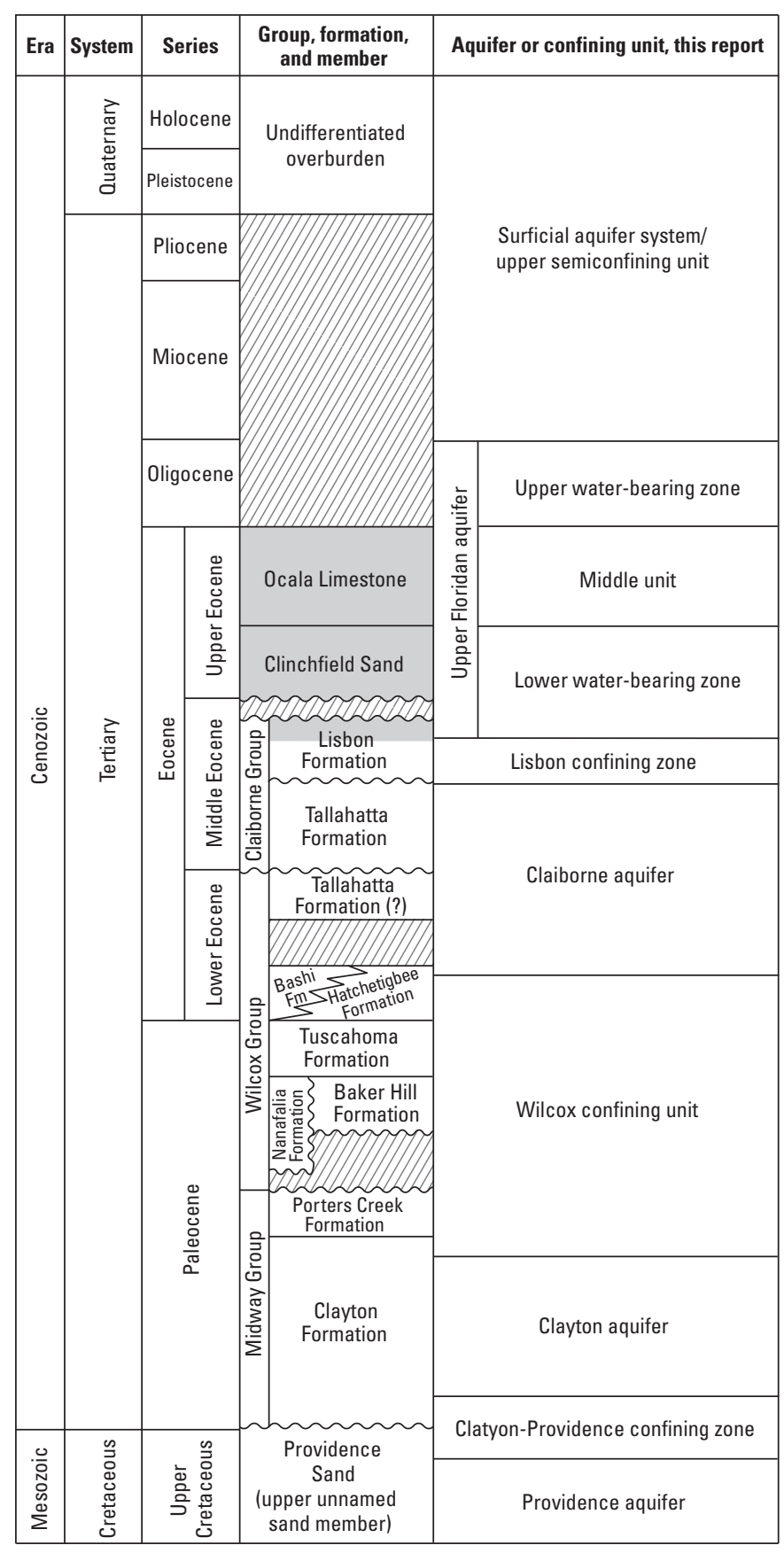

Middle Eocene and younger modified from Hicks and others (1987). Lower Eocene and older modified from Clarke and others (1984).

\section{EXPLANATION}

Sediments composing Upper Floridan aquifer

Absent from area

Figure 2. Generalized stratigraphy and hydrologic units underlying Albany and surrounding areas, southwestern Georgia. 
College of Environmental Sciences, n.d.). During 2015, Camilla received about 54 in. of rainfall and Arlington received about 56 in. Rainfall was also above average during the last quarter of 2015. From October 1 to December 31, 2015, about 12 in. of rain fell in Camilla, which was about 2.6 in. above normal. During the same time period, about 16.8 in. of rain fell in Arlington, which was 6.9 in. above normal. During the data collection phase of this study, the area continued to experience normal to above-normal rainfall.

A hydrograph for well 12K014 in Baker County shows that water levels in the Upper Floridan aquifer were near the daily median (normal conditions) from June to November 2015, then primarily above normal from November 2015 to May 2016 (fig. 3A). A hydrograph for well 11J011 in Mitchell
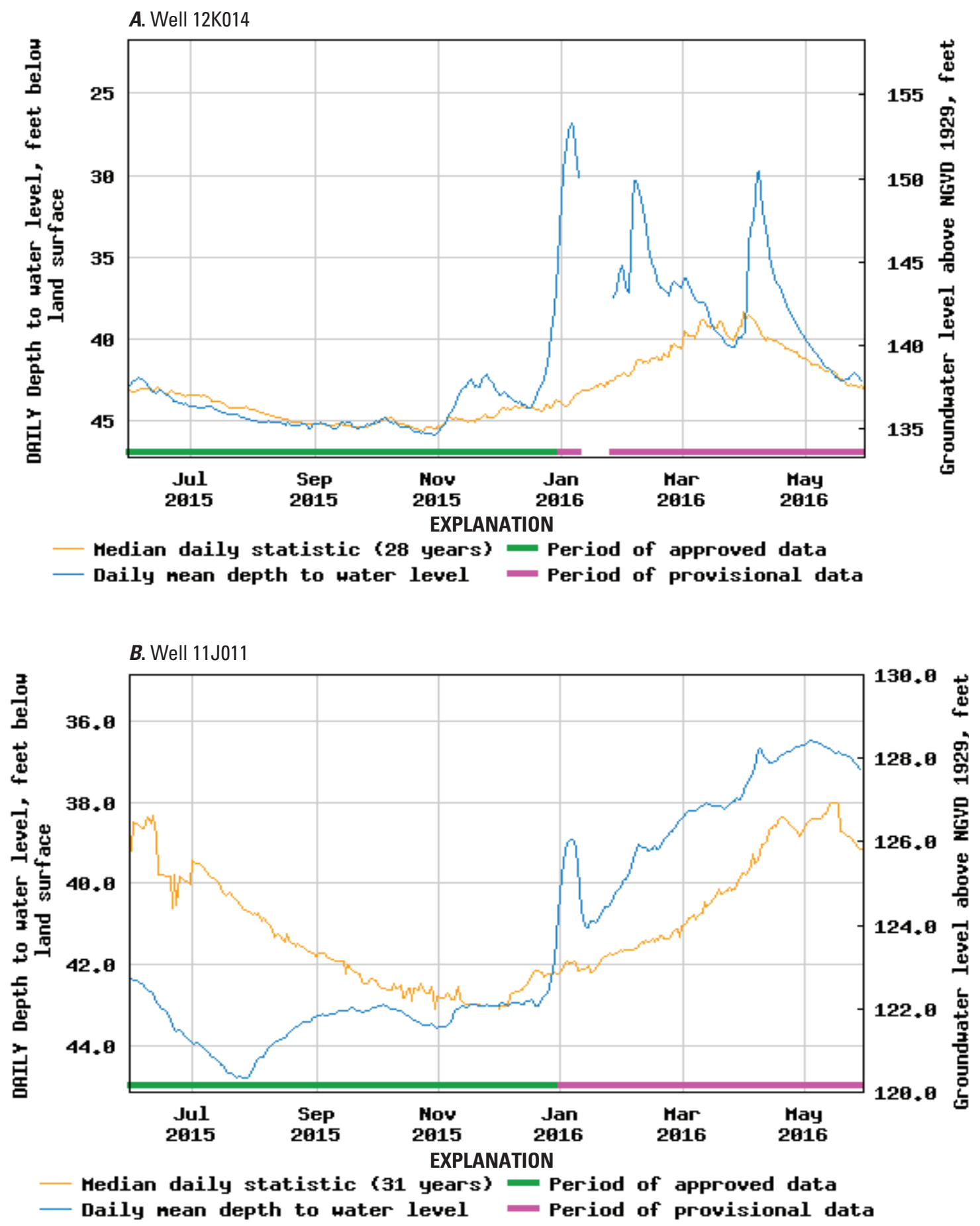

Figure 3. Hydrographs of wells, $A, 12 \mathrm{~K} 014$ in the Upper Floridan aquifer and, $B, 11 \mathrm{~J} 011$ in the Claiborne aquifer in southwest Georgia, June 2015 through May 2016. 
County shows that water levels in the Claiborne aquifer were below normal from June to November 2015 and above normal from December 2015 to May 2016 (fig. 3B). Increases in water levels in the two aquifers reflect recharge from rainfall during fall 2015, but also reflect the end of the irrigation pumping season in southwestern Georgia.

\section{Methods of Investigation}

For this investigation, data were compiled from existing sources, new wells were constructed, borehole geophysical logs were collected, and aquifer tests were performed and analyzed. Many different methods were used to compile, collect, and analyze the data.

\section{Compilation of Existing Data}

Existing data were compiled from NWIS and GaEPD Agricultural Unit permitting files. The NWIS database (U.S. Geological Survey, 2016) contains numerous well records from previous studies. Data compiled from NWIS include geologic logs, borehole geophysical logs, and hydrogeologic properties. The GaEPD provided well permit records that contain information about well construction, driller's logs, and pumping and drawdown data. The GaEPD well permit records are from recent permits for irrigation wells utilizing the Claiborne aquifer (Edward Rooks, Georgia Environmental Protection Division, written commun., 2015, 2016). The

GaEPD also provided geophysical logs and the core from well 10J011 installed in Elmodel, Ga.

\section{Borehole Geophysical Logging}

The USGS collected borehole geophysical logs in seven wells in the study area (table 1). The wells included five newly permitted irrigation wells and two wells constructed for this project. The borehole geophysical logs include caliper, singlepoint resistance, spontaneous potential, long and short normal resistivity, lateral resistivity, fluid temperature, fluid resistivity, and natural gamma. These borehole geophysical data, along with borehole geophysical data from NWIS and the GaEPD, were used to better define the tops and bases of the Upper Floridan and Claiborne aquifers and develop cross sections through the study area.

\section{New Well Construction}

Wells were constructed by USGS drillers using mud and air-rotary techniques at two sites in the study area, such that each site would have a Claiborne aquifer production well, a Claiborne aquifer monitoring well, and an Upper Floridan aquifer monitoring well. The sites are located at the University of Georgia Stripling Irrigation Research Park (Stripling site; fig. 1) in Mitchell County and at a private farm in Early County (Newberry site; fig. 1). Data collected at the new well construction sites were entered into NWIS.

The Stripling site had an existing, 8-in.-diameter, Claiborne-aquifer production well (11J029), so a 2.5-in.diameter Claiborne-aquifer well (11J025) and 2.5-in.-diameter Upper Floridan aquifer monitoring well (11J030) were installed 36.3 and 17.8 feet (ft) to the southeast, respectively. The construction of the Claiborne aquifer monitoring well is similar to that of the production well, with a total depth of $700 \mathrm{ft}, 560 \mathrm{ft}$ of casing, and screened intervals from 460 to 540,600 to 620,640 to 660 , and 680 to $700 \mathrm{ft}$ below land surface (table 1).

The Newberry site (fig. 1) had an existing 4-in.-diameter Upper Floridan aquifer well (08K001), so an 8-in.-diameter production well (08K026) and a 2.3-in.-diameter monitoring well (08K025) were installed in the Claiborne-aquifer for this study. The existing Upper Floridan aquifer monitoring well is $125 \mathrm{ft}$ deep, with blank casing from 0 to $61 \mathrm{ft}$ and open hole from 61 to $125 \mathrm{ft}$ below land surface. The Claiborne-aquifer production well is $295 \mathrm{ft}$ deep, with blank casing from 0 to $215 \mathrm{ft}$, and screened casing from 215 to $295 \mathrm{ft}$ below land surface. The Claiborne-aquifer monitoring well is $290 \mathrm{ft}$ deep, with blank casing from 0 to $220 \mathrm{ft}$ and screened casing from 220 to $280 \mathrm{ft}$ below land surface (table 1).

Cuttings were collected at 10-ft intervals during the drilling process and described by a USGS geologist. The cutting descriptions were used with the borehole geophysical logs to determine the depth of the top and base of the aquifers and confining units, and aid in well construction.

\section{Aquifer Test Design and Analysis}

Two 72-hour aquifer tests were performed during this study, one at the Stripling site and the other at the Newberry site. Each test utilized a Claiborne aquifer pumping well and Claiborne and Upper Floridan aquifer monitoring wells, as shown in figure 4.

\section{Water-Level Measurements}

Continuous and intermittent groundwater-level measurements were made at aquifer test wells during the study in accordance with USGS standard procedures (Stallman, 1971; Cunningham and Schalk, 2011). Water-level data collected for the aquifer tests are available in Gordon and Gonthier, (2017), and the data used to interpret the aquifer tests were entered into NWIS.

Manual, intermittent water-level measurements were made for calibration or backup of groundwater-level recorder measurements (continuous records) in monitoring wells. Manual measurements were made to the nearest $0.01 \mathrm{ft}$ using an electric tape following procedures described in Cunningham and Schalk (2011). Nearby existing wells already instrumented with continuous water-level recorders as part of the USGS statewide 
Table 1. Well construction data for selected wells in the study area, southwestern Georgia.

[USGS, U.S. Geological Survey. Aquifer test well: MW, aquifer test monitor or observation well; PW, aquifer test pumped well; - , not aquifer test well. ft, foot; NAVD 88, North American Vertical Datum of 1988. Open interval type: SCR, screen; OH, open hole. n.d., no data]

\begin{tabular}{|c|c|c|c|c|c|c|c|c|c|c|c|}
\hline $\begin{array}{l}\text { USGS } \\
\text { well } \\
\text { identifier }\end{array}$ & $\begin{array}{l}\text { Aquifer } \\
\text { test } \\
\text { well }\end{array}$ & County & Aquifer & $\begin{array}{c}\text { Aquifer } \\
\text { thickness } \\
\text { (ft) }\end{array}$ & $\begin{array}{l}\text { Land- } \\
\text { surface } \\
\text { altitude } \\
\text { (ft above } \\
\text { NAVD 88) }\end{array}$ & $\begin{array}{c}\text { Well } \\
\text { total } \\
\text { depth } \\
\text { (ft) }\end{array}$ & $\begin{array}{l}\text { Casing } \\
\text { depth } \\
\text { (ft) }\end{array}$ & $\begin{array}{c}\text { Well open } \\
\text { interval } \\
\text { (ft below } \\
\quad \text { land } \\
\text { surface) }\end{array}$ & $\begin{array}{c}\text { Open } \\
\text { interval } \\
\text { type }\end{array}$ & $\begin{array}{l}\text { Diameter } \\
\text { (inches) }\end{array}$ & $\begin{array}{l}\text { Geophysical } \\
\text { logs } \\
\text { collected }\end{array}$ \\
\hline 05H007 & - & Early & Claiborne & 272 & 160 & 455 & 185 & n.d. & SCR & 8 & No \\
\hline 06G018 & - & Seminole & Claiborne & 268 & 140 & 700 & 400 & $400-700$ & SCR & 6 & Yes \\
\hline 07F014 & - & Seminole & Claiborne & 320 & 115 & 720 & 400 & n.d. & SCR & 10 & No \\
\hline 08F515 & - & Decatur & Claiborne & 400 & 110 & 800 & 380 & n.d. & SCR & 12 & No \\
\hline 08H016 & - & Miller & Claiborne & 170 & 155 & 740 & 300 & n.d. & SCR & 6 & Yes \\
\hline 08K001 & MW & Early & Upper Floridan & 80 & 224 & 125 & 61 & $61-125$ & $\mathrm{OH}$ & 4 & No \\
\hline 08K025 & MW & Early & Claiborne & 70 & 230 & 290 & 220 & $220-290$ & SCR & 2.3 & Yes \\
\hline 08K026 & PW & Early & Claiborne & 70 & 224 & 310 & 215 & $215-295$ & SCR & 8 & No \\
\hline 09G020 & - & Decatur & Claiborne & 185 & 135 & 780 & 500 & n.d. & SCR & 10 & Yes \\
\hline 10J011 & - & Baker & Clayton & 147 & 158 & 805 & 660 & n.d. & SCR & 6 & Yes \\
\hline 11H016 & - & Mitchell & Claiborne & 256 & 161 & 800 & 520 & n.d. & SCR & 10 & Yes \\
\hline 11J011 & MW & Mitchell & Claiborne & nd & 165 & 417 & 398 & n.d. & SCR & 4 & No \\
\hline $11 \mathrm{~J} 023$ & - & Baker & Claiborne & 156 & 168 & 560 & 340 & n.d. & SCR & 6 & Yes \\
\hline \multirow[t]{4}{*}{$11 \mathrm{~J} 025$} & MW & Mitchell & Claiborne & 260 & 161 & 710 & 460 & $460-540$ & SCR & 6 & No \\
\hline & & & & & & & & $600-620$ & & & No \\
\hline & & & & & & & & $640-660$ & & & No \\
\hline & & & & & & & & $680-700$ & & & No \\
\hline \multirow[t]{4}{*}{$11 \mathrm{~J} 029$} & PW & Mitchell & Claiborne & 260 & 162 & 700 & 460 & $460-540$ & SCR & 8 & Yes \\
\hline & & & & & & & & $600-620$ & & & No \\
\hline & & & & & & & & $640-660$ & & & No \\
\hline & & & & & & & & $680-700$ & & & No \\
\hline 11J030 & MW & Mitchell & Upper Floridan & 105 & 161 & 236 & 60 & $60-236$ & $\mathrm{OH}$ & 2.5 & No \\
\hline 11P001 & - & Lee & Claiborne & 75 & 330 & 180 & 105 & n.d. & SCR & 4 & No \\
\hline $12 \mathrm{~L} 403$ & - & Dougherty & Claiborne & 214 & 180 & 452 & 227 & n.d. & SCR & 12 & Yes \\
\hline 13L016 & - & Dougherty & Claiborne & 260 & 207 & 560 & 300 & n.d. & SCR & 4 & No \\
\hline 13L017 & - & Dougherty & Claiborne & 260 & 204 & 550 & 290 & n.d. & SCR & 4 & No \\
\hline 13L021 & - & Dougherty & Claiborne & 309 & 203 & 560 & 300 & $\begin{array}{c}300-470 \\
520-550\end{array}$ & $\mathrm{SCR}$ & 12 & Yes \\
\hline 13L022 & - & Dougherty & Claiborne & 260 & 206 & 550 & 290 & $\begin{array}{c}290-460 \\
510-540\end{array}$ & SCR & 12 & Yes \\
\hline 13L027 & - & Dougherty & $\begin{array}{r}\text { Claiborne/ } \\
\text { Clayton }\end{array}$ & nd & 201 & 942 & 300 & n.d. & SCR & 4 & No \\
\hline 14N016 & - & Worth & Claiborne & 216 & 264.5 & 460.75 & 210 & n.d. & SCR & & No \\
\hline 14Q209 & - & Sumpter & Claiborne & 100 & 340 & 280 & 180 & n.d. & SCR & 16 & Yes \\
\hline $15 \mathrm{~L} 035$ & - & Worth & Upper Floridan & 250 & 410 & 430 & 180 & n.d. & $\mathrm{OH}$ & 4 & No \\
\hline $15 \mathrm{~N} 008$ & - & Worth & Claiborne & 74 & 270 & 334 & 260 & n.d. & SCR & 6.5 & Yes \\
\hline 16M057 & - & Turner & Claiborne & 142 & 360 & 612 & 470 & n.d. & SCR & 10 & No \\
\hline
\end{tabular}




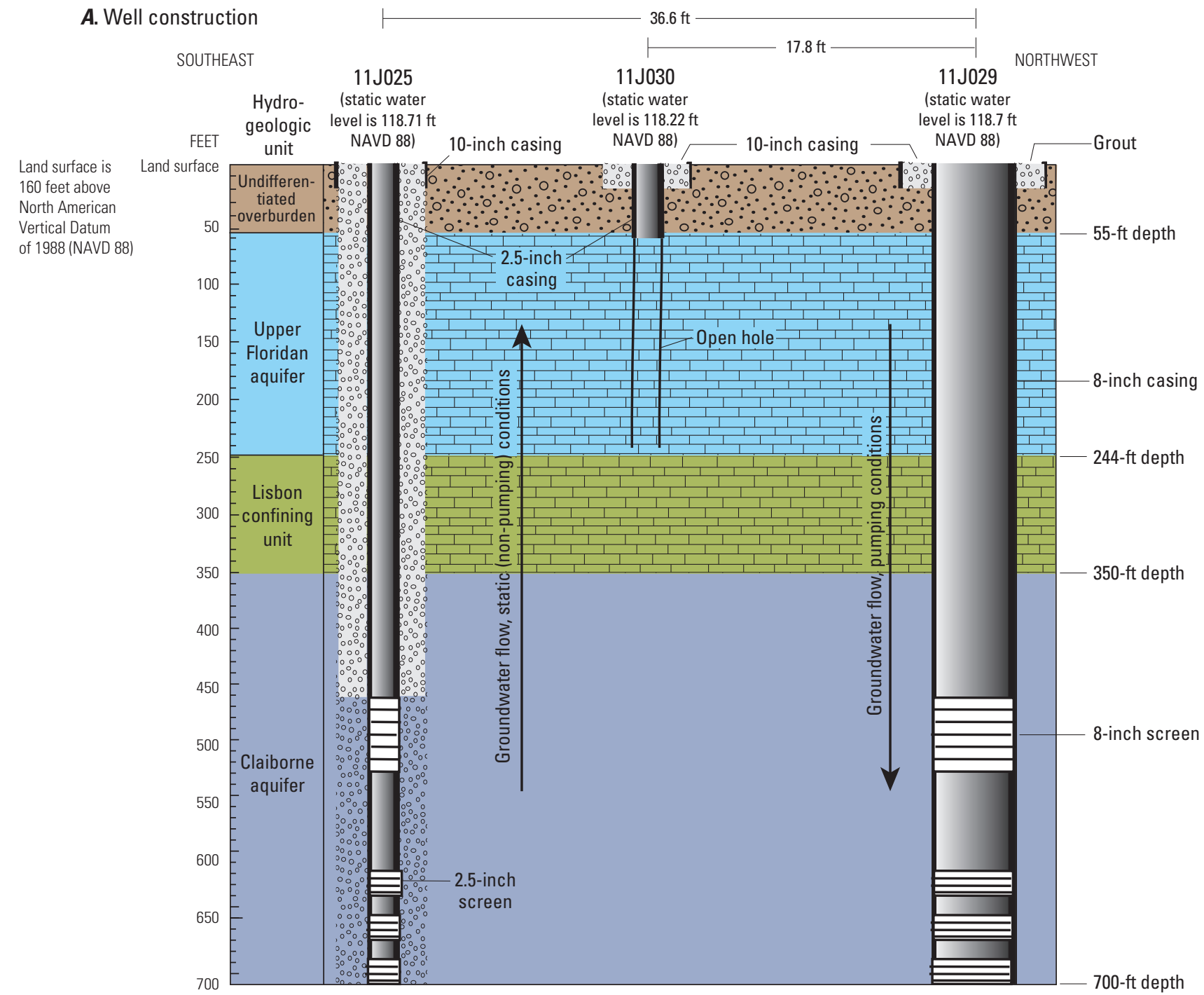

B. Aquifer test layout

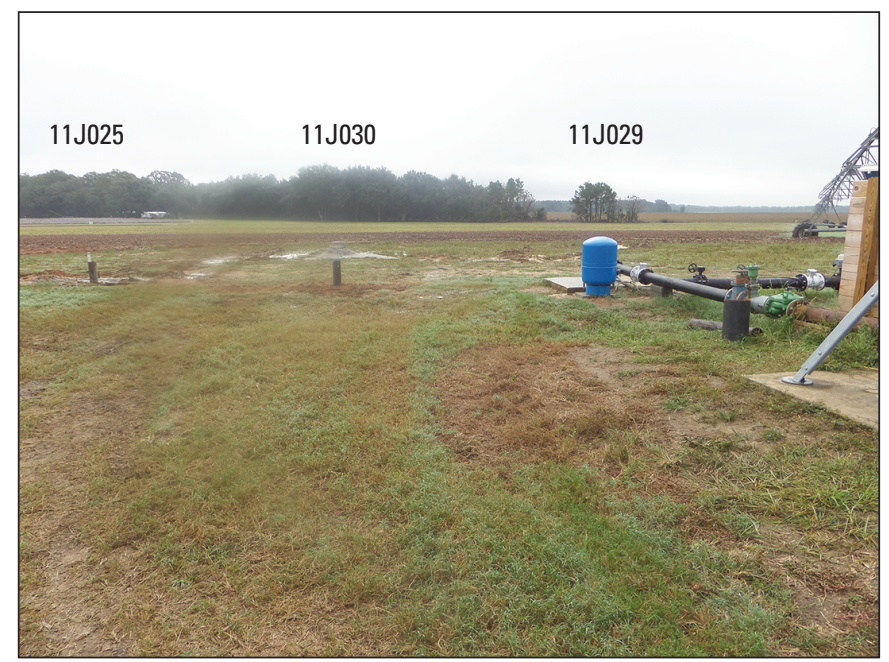

Figure 4. $A$, Well construction, and $B$, aquifer test layout, Stripling Research site, northwest of Camilla, Georgia, December 15-18, 2015. 
groundwater-level monitoring network were used where available. Additional monitoring wells also were equipped with continuous recorders to obtain background water levels before and after aquifer testing. Continuous water levels were recorded once every hour during non-pumping (background) conditions and as frequently as once every 5 seconds during the start and stop of pumping during the tests. Water-level recorders were submerged, vented pressure transducers. Pertinent details about the test designs are provided below within each aquifer-test section.

\section{Measurement of Pumping Rate}

The pumping rate or flow rate (discharge) for aquifer tests were reported in gallons per minute. At the Stripling site, discharge was measured using a factory-calibrated Seametric AG200-600 meter. The discharge for the aquifer test at the Newberry site was measured using a weir containing a 3-in.diameter orifice on a 4-in. pipe and a manometer, as described by Cunningham and Schalk (2011). Measurements were collected through the duration of the pumping phase of both tests to ensure nearly constant pumping rates. Discharge was assumed to be zero once the pump was shut off.

\section{Drawdown Estimation}

Drawdown is defined as the water-level change in a well in response to pumping from the groundwater system. The change in water level after the end of the pumping phase of the test is commonly referred to as residual drawdown (Ferris and others, 1962). A drawdown time series is the drawdown as a function of time after the start of pumping $(t)$ and time after the end of pumping $\left(t^{\prime}\right)$. Estimating drawdown involves quantifying the water-level change resulting from both pumping and non-pumping influences, and removing the water-level change attributed to non-pumping influences. Details about drawdown estimation are discussed within the Stripling and Newberry aquifer-test sections of this report.

\section{Analytical Methods}

Analytical solutions provided preliminary assessments of hydraulic properties using assumptions of a relatively simple hydrogeologic setting and provided insight into what factors might be affecting drawdown. The Theis (1935) and Cooper-Jacob (1946) methods are based on the same analytical solution for the radial coordinate system partial differential equation for flow to a well in a confined aquifer and both assume the following:

- The aquifer has an infinite extent and uniform thickness, and is horizontal, homogenous, and isotropic.

- The aquifer is fully confined.
- Discharge is fully derived from storage within the aquifer.

- The initial potentiometric surface is horizontal.

- The well fully penetrates the confined aquifer, resulting in horizontal, laminar flow to the pumping well.

- The pumping well is infinitesimally small in diameter, thus has no wellbore storage.

- Well discharge occurs at a constant rate.

Under these assumed conditions, drawdown with distance from the pumped well and time is defined using the Theis (1935) equation:

$$
s_{r, t}=\frac{Q}{4 \pi T} W(u)
$$

where

$s \quad$ is the drawdown or water-level change in response to a constant pumping rate, in feet;

$r \quad$ is the distance from the center of the pumping well, in feet;

$t \quad$ is time since the start of constant pumping, in days;

$Q \quad$ is the discharge or pumping rate, in cubic feet per day;

$T \quad$ is the transmissivity of the aquifer, in square feet per day; and

$W(u) \quad$ is called the Theis function where: $u=\frac{r^{2} S}{4 T t}$, and

$S \quad$ is the storage coefficient of the aquifer, dimensionless.

Cooper and Jacob (1946) found that with a large enough $t / r$ ratio, drawdown on a semi-log plot (drawdown on the y-axis, $\log$ [time] on the $\mathrm{x}$-axis) is approximately linear, and the Theis equation can be approximated by a simplified equation:

$$
s \cong \frac{Q}{4 \pi T} \ln \left(\frac{4 T t}{e^{\gamma} r^{2} S}\right)
$$

where

$e \quad$ is the natural log number 2.718281828 , and

$\gamma \quad$ is Euler's constant 0.5772156649 .

From equation 2:

$$
\begin{gathered}
S \cong \frac{4 T t_{0}}{e^{\gamma} r^{2}} \cong \frac{2.24584 T t_{0}}{r^{2}} ; \text { and } \\
T \cong\left(\frac{\ln (10) Q}{4 \pi\left(s_{2}-s_{1}\right)}\right) \log \left(\frac{t_{2}}{t_{1}}\right) .
\end{gathered}
$$


where

$$
\begin{array}{cc}
t_{0} & \text { is the time after the start of pumping when an } \\
\text { extension of the straight line of drawdown } \\
\text { on a semi-log plot is zero, in days; } \\
s_{1} \quad \text { is the drawdown at time } t_{1} \text {, in feet; } \\
s_{2} \quad \text { is the drawdown at time } t_{2} \text {, in feet; and } \\
t_{1}, t_{2} \quad \begin{array}{l}
\text { are times after the start of pumping, with } t_{2} \\
\text { greater than time } t_{1} .
\end{array}
\end{array}
$$

Storage coefficient estimates in single-well tests are not reliable (Halford and Kuniansky, 2002; Halford and others, 2006). A Microsoft Excel spreadsheet produced by Halford and Kuniansky (2002) uses the Cooper-Jacob method to determine the transmissivity. Because storage coefficient estimates are not reliable for single-well tests, the spreadsheet does not calculate the storage coefficient. Where some monitoring wells extend a distance away from the center of pumping, data from the spreadsheet were used to estimate the storage coefficient.

Papadopulos and Cooper (1946) published type curves (used to determine drawdown as a function of time) following some of the same assumptions for a confined aquifer as the Theis and Cooper-Jacob methods. Unlike the Theis and Cooper-Jacob methods, however, the Papadopulos-Cooper type-curve methods consider the effects of wellbore storage, which is not assumed to be negligible. The PapadopulosCooper method is useful for determining when the well bore storage effects likely occur during an aquifer test.

Walton (1962) and Hantush (1960) published type-curve methods that are modifications of the Theis and Cooper-Jacob methods. Some of the same assumptions made in the Theis and Cooper-Jacob methods are followed, but the aquifer is not assumed to be fully confined and leakage is assumed to occur between the pumped aquifer and an aquifer above or below it. Walton (1962) assumed that changes in storage in the semiconfining unit are negligible, and Hantush (1960) assumed that changes in storage in the semi-confining unit are appreciable (Kruseman and de Ridder, 1990). These methods are useful for determining whether a certain type of leakage is occurring during an aquifer test.

Theis concepts and temporal superposition (Ferris and others, 1962; Reilly and others, 1984) can be used to simulate the effects of multiple pumping events. These concepts can be used to estimate drawdown response to an aquifer test and to estimate the hydraulic properties of the aquifer being tested.

A Microsoft Excel macro that uses Theis concepts and temporal superposition was used at the Newberry site to simulate the effects of multiple pumping events through time (SUMTheis function; Keith J. Halford, U.S. Geological Survey, written commun., 2010).

Drawdown time series were inspected on log-log plots and semi-log plots with drawdown on the y-axis and log(time) on the X-axis. As described earlier, analytical methods use key patterns (type curves) on log-log and semi-log plots. In order to compare minor but important differences between observed and type-curve drawdown, the semi-log slope of drawdown $\left(m_{\mathrm{s}}\right)$ is also plotted against $\log ($ time$)$ on semi-log plots. The semi-log slope of drawdown is the change in drawdown divided by a change in $\log$ (time), in feet per $\log$ (day):

$$
m_{s}=\frac{\left(s_{2}-s_{1}\right)}{\log \left(\frac{t_{2}}{t_{1}}\right)} .
$$

\section{Axisymmetric Modelling}

Aquifer-test data at the Stripling site were analyzed by simulating drawdown response to pumping using an axisymmetric, groundwater-flow model. An axisymmetric-flow model uses a two-dimensional rectangular grid that is radially fanned out into a cylinder with the pumped well at its center. The model's two dimensions are depth and distance from the center of pumping. Depth is represented by rows and horizontal distance from pumping is represented by columns. The depth and distance make up the one traditional model layer. Hydraulic properties vary as a function of depth, represented by the model rows. Values of hydraulic properties (horizontal hydraulic conductivity, $\mathrm{K}_{\mathrm{x}}$, vertical hydraulic conductivity, $\mathrm{K}_{\mathrm{y}}$, and specific storage) are multiplied by $2 \pi r$, where $r$ is the distance between the centroid of the cell representing the pumping well and the center of the cell representing the right edge of the rectangular grid. Multiplying the hydraulic properties by $2 \pi r$ radially fans the two-dimensional rectangle of the model out 360 degrees to form the cylinder. Full descriptions of the derivation of two-dimensional radial models using a single layer or multiple layers are provided in Rutledge (1991), Reilly and Harbaugh (1993), Clemo (2002), Langevin (2008), and Halford (2009).

\section{Model Calibration}

The match between simulated and observed drawdown is determined either by curve fitting on charts or by an objective function. Matches were objectively quantified using the root mean square of the difference between simulated and observed drawdown $(R M S)$ :

$$
R M S=\sqrt{\frac{\sum_{i=1}^{n}\left(\hat{s}_{i}-s_{i}\right)^{2}}{n}} .
$$

where

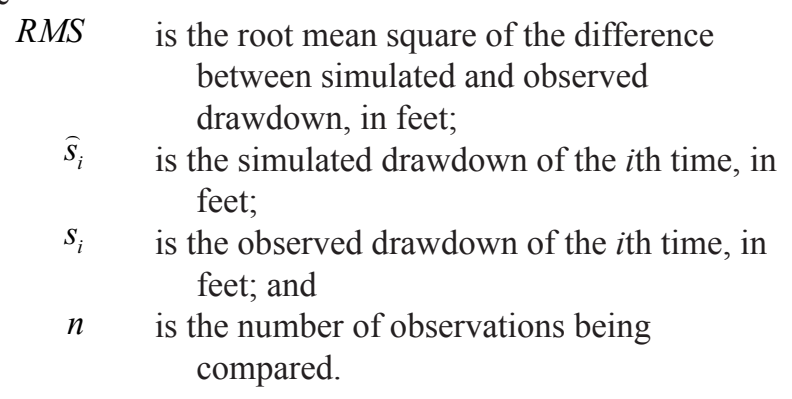


Observations are distributed through time. The smaller the $R M S$ value, the better the fit between simulated and observed drawdown. To compare wellness-of-fit between wells, the $R M S$ for each well was normalized (divided) by the well's maximum drawdown $(\operatorname{Max} D D)$ in response to the aquifer test. In the case that the simulation is trying to fit two wells simultaneously, the MaxDD for both wells is incorporated into equation 6 as follows:

$$
R M S^{\prime}=\sqrt{\frac{\left(\frac{\sum_{i=1}^{n_{1}}\left(\widehat{s}_{1, i}-s_{1, i}\right)^{2}}{M a x D D_{1}^{2}}\right)+\left(\frac{\sum_{j=1}^{n_{2}}\left(\widehat{s}_{2, j}-s_{2, j}\right)^{2}}{M a x D D_{2}^{2}}\right)}{n_{1}+n_{2}}},
$$

where

$\widehat{s}_{1, i} \quad$ is the simulated drawdown of the $i$ th time of the first well, in feet;

$s_{1, i} \quad$ is the observed drawdown of the $i$ th time of the first well, in feet;

$\operatorname{Max} D D_{1} \quad$ is the maximum drawdown of the first well, in response to the aquifer test, in feet;

$\widehat{s}_{2, j} \quad$ is the simulated drawdown of the $j$ th time of the second well, in feet;

$s_{2, j} \quad$ is the observed drawdown of the $j$ th time of the second well, in feet;

$\mathrm{MaxDD}_{2} \quad$ is the maximum drawdown of the second well, in response to the aquifer test, in feet;

$n_{1} \quad$ is the number of observations of the first well; and

$n_{2} \quad$ is the number of observations of the second well.

$\operatorname{Max} D D$ is the drawdown observed at the end of the aquifer test. The prime for $R M S^{\prime}$ denotes that $\operatorname{MaxDD}$ for two wells is incorporated into the RMS equation. The RMS values of the difference between simulated and observed drawdown for different model input values of hydraulic parameters are available in Gordon and Gonthier (2017).

\section{Hydrogeology}

The hydrogeology of the study area was refined based on new information collected during this study. Borehole geophysical logs and geologic logs from cuttings descriptions were used to define the tops and bases of the aquifers and confining units at these new well sites. Geophysical logs of natural gamma and resistivity were especially useful in determining the tops, bases, and water-bearing zones within the hydrogeologic units. The clay within the confining units typically has high values of natural gamma radiation, whereas the limestone within the Upper Floridan aquifer and parts of the Claiborne aquifer has very low values of natural gamma radiation. Water-bearing zones within the aquifers have relatively high resistivity values. Final well construction was based on the data provided by the geophysical logs and geologic logs.

The top of the Upper Floridan aquifer is marked at the contact between clay, sand, and gravel with a high natural gamma signature and limestone with a much lower natural gamma signature. The base of the Upper Floridan aquifer is marked by the contact between hard, tan limestone and gray or green soft limestone and clay with a higher gamma signature. The top of the Claiborne aquifer is marked by sand and (or) limestone having a low gamma signature. The composition of the Claiborne aquifer typically alternates between limestone, silty sand, and clay; therefore, not all of the aquifer is water-bearing. The water-bearing zones typically correspond to layers with high sand and (or) limestone content. These zones typically have higher values of resistivity than less water-bearing clays and silts. For example, wells 11J025 and 08K025 are screened through water-bearing zones having relatively high resistivity within the Claiborne aquifer (figs. 5 and 6). The contact between the Claiborne aquifer and the Wilcox confining unit typically is marked by the presence of gray, silty clay that has a high natural gamma signature and low resistivity.

Two cross sections show the thickness and extent of the hydrogeologic units from land surface through the Claiborne aquifer (fig. 7; see fig. 1 for section locations). Section $A-A^{\prime}$ extends from well $08 \mathrm{~K} 025$ in eastern Early County southeast to well 11J025 in Mitchell County. Section $B-B^{\prime}$ extends from well 06G018 in Seminole County northeast to well 14N016 in northern Worth County. The Upper Floridan and Claiborne aquifers thicken and deepen toward the east and south.

Maps of the top and base of the Claiborne aquifer were created to show its extent within the study area. The top of the Claiborne aquifer extends from an altitude of about $200 \mathrm{ft}$ in Terrell County to about $-402 \mathrm{ft}$ in Decatur County (fig. $8 \mathrm{~A}$ ). The base of the Claiborne aquifer extends from an altitude of about $60 \mathrm{ft}$ in eastern Sumter County to below $-750 \mathrm{ft}$ in Decatur County (fig. $8 B$ ). The thickness of the Claiborne aquifer in the study area (table 1) ranges from $70 \mathrm{ft}$ in wells 08K025 and 08K026 in eastern Early County to $400 \mathrm{ft}$ in Decatur County (fig. 9).

\section{Claiborne Aquifer Hydrology and Interconnection With the Upper Floridan Aquifer}

The hydrologic properties of the Claiborne aquifer presented in this report were compiled from the USGS Groundwater Site Inventory (GWSI) database, GaEPD files, previous reports, and calculated from data collected during two aquifer tests. The hydrologic data include transmissivity, hydraulic conductivity, and storage coefficient values. Transmissivity values calculated from aquifer test data were used where available and estimated from reported specific capacity values 


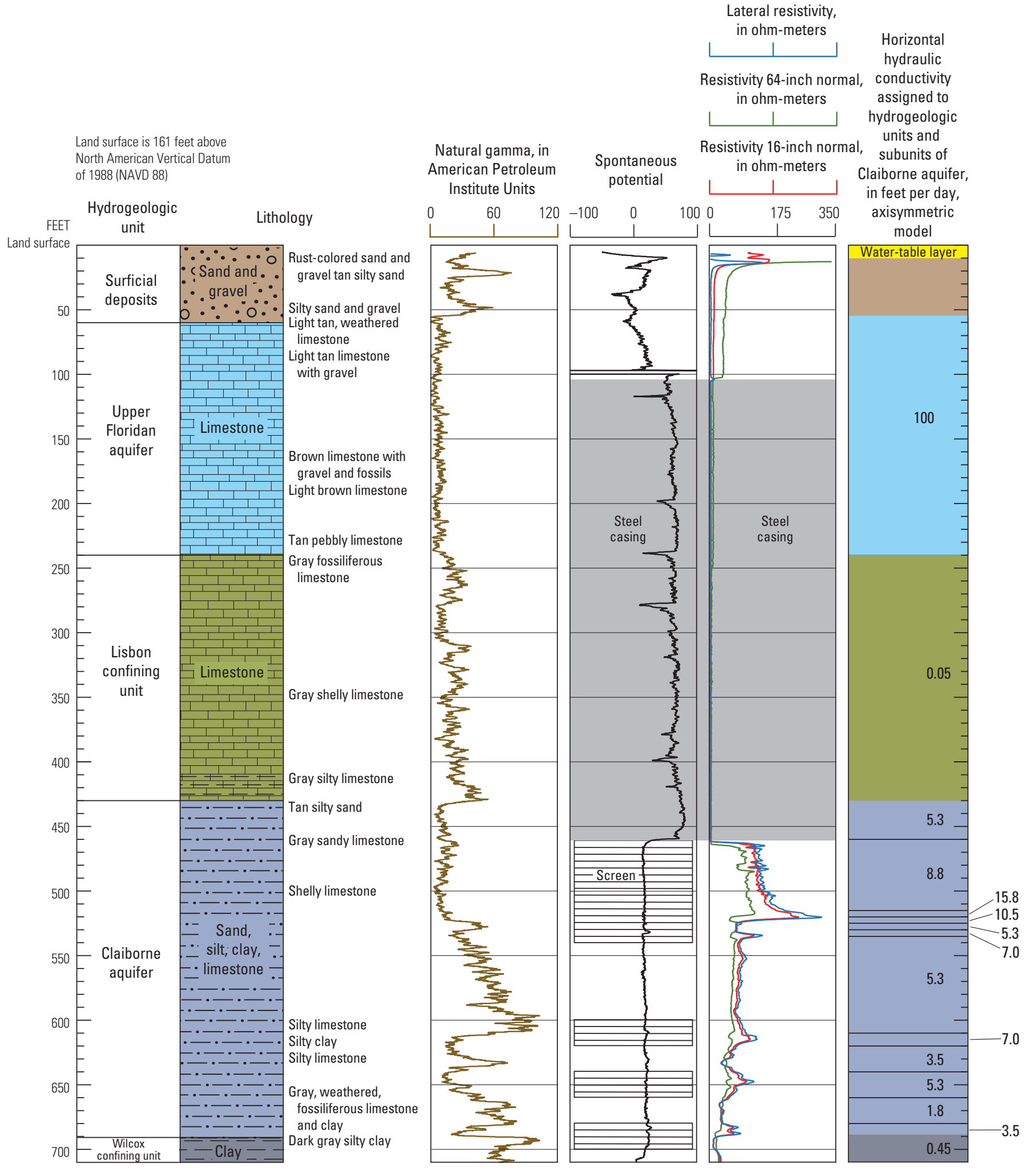

Figure 5. Hydrogeologic units, borehole geophysical logs in Claiborne aquifer monitoring well 11J025, and values of horizontal hydraulic conductivity assigned to layers of the axisymmetric model, 72-hour aquifer test, Stripling research site, near Camilla, Georgia, December 15-18, 2015. 


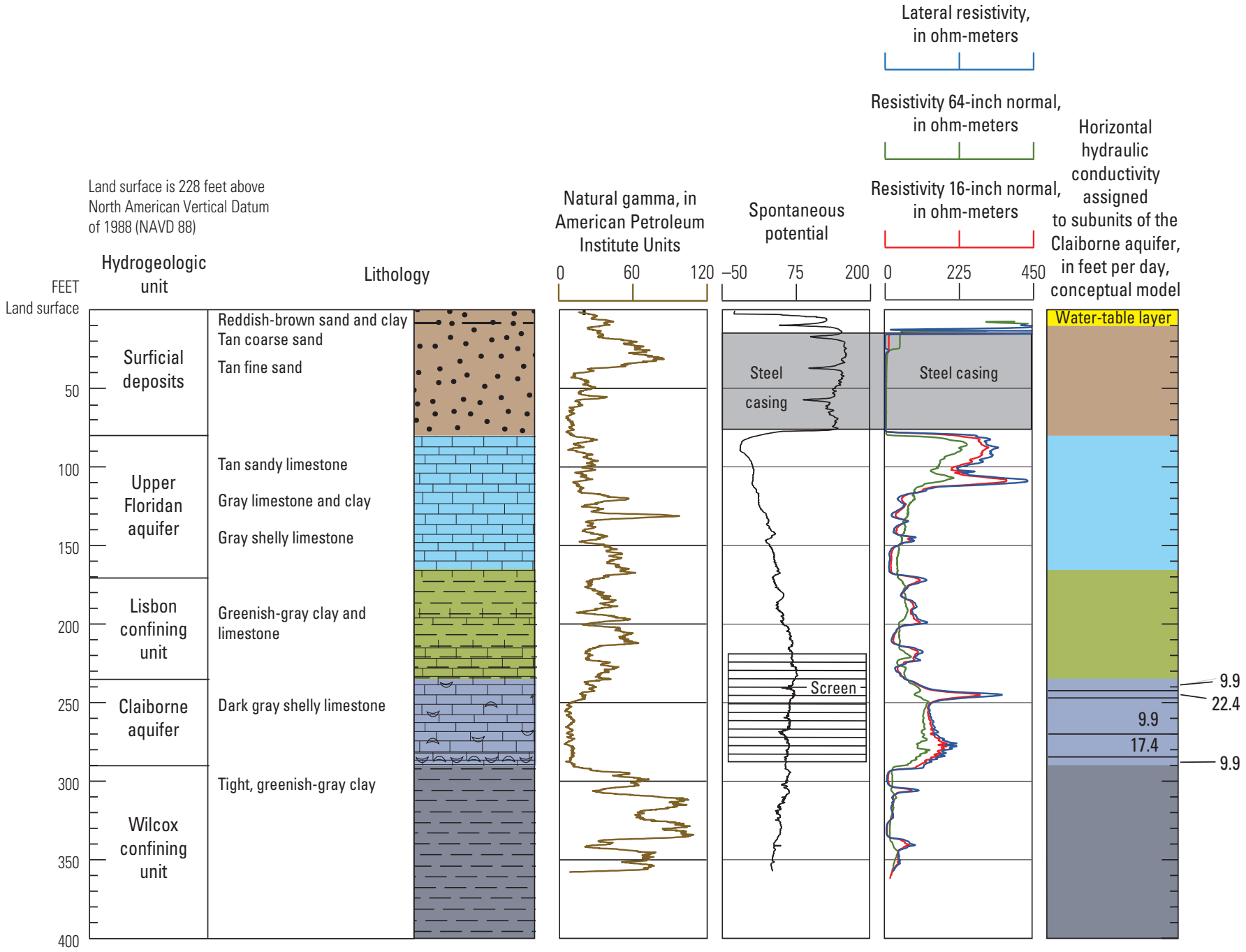

Figure 6. Hydrogeologic units, borehole geophysical logs in Claiborne aquifer monitoring well 08K025, and values of horizontal hydraulic conductivity assigned to layers of the axisymmetric model, 72-hour aquifer test, Newberry site, northeast Early County, southeast of Arlington, Georgia, March 14-17, 2016.

where aquifer-test data were not available. Several sets of aquifer-test data are available in NWIS (U.S. Geological Survey, 2016) and in previously published reports, and two sets of data were collected as part of this study and are available in Gordon and Gonthier (2017). Data from the two new aquifer tests conducted at the Stripling and Newberry sites provide additional information about hydrologic properties of the Claiborne aquifer and were used to evaluate the interconnection between the Claiborne and Upper Floridan aquifers.

\section{Stripling Aquifer Test}

To determine the hydraulic properties of the Claiborne aquifer and adjacent confining units, Claiborne aquifer well $11 \mathrm{~J} 029$ was pumped at an average rate of 579 gallons per minute (gal/min) beginning at 9:00:20 a.m. on December 15,2015 , and continued for 72 hours and 10 seconds until 9:00:30 a.m. on December 18, 2015. Water levels in well
11J029 and three observation wells (11J030, 11J025, and 11J011) were monitored during the aquifer test. Well 11J030 is open (not screened) from 60 to $236 \mathrm{ft}$ below land surface within the Upper Floridan aquifer and is located about $18 \mathrm{ft}$ from the pumped well (fig. 4). Wells 11J025 and 11J029 are screened through the Claiborne aquifer, each having four screens that extended from 460 to 540,600 to 620,640 to 660 , and 680 to $700 \mathrm{ft}$ below land surface (fig. 5). Well 11J025 (fig. 4) is located $36 \mathrm{ft}$ from the pumped well. Well 11J011 is a Claiborne-aquifer monitoring well located about 2-1/4 miles (mi) northwest of the Stripling site, near Newton, Ga., and is part of the USGS existing statewide network of groundwaterlevel recorders (fig. 1). Well construction information for all wells used during the Stripling aquifer test is listed in table 2.

Observed drawdown of Claiborne aquifer monitoring well 11J025 was compared to analytical type curves to gain insight about how the aquifer responds to pumping. Data that deviate from the type curves indicate that the aquifer does not 

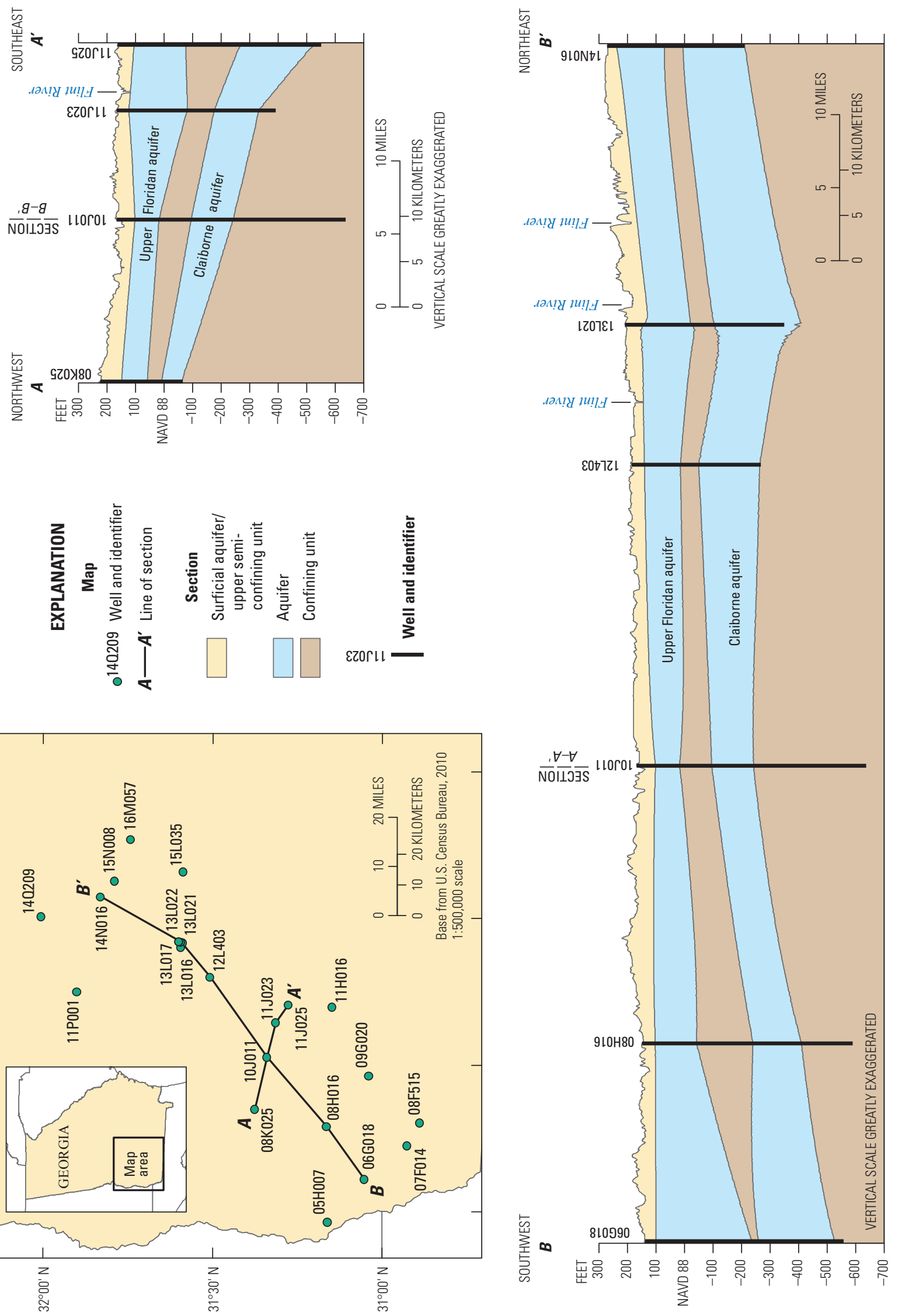

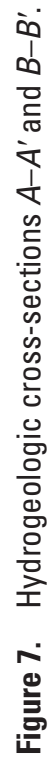



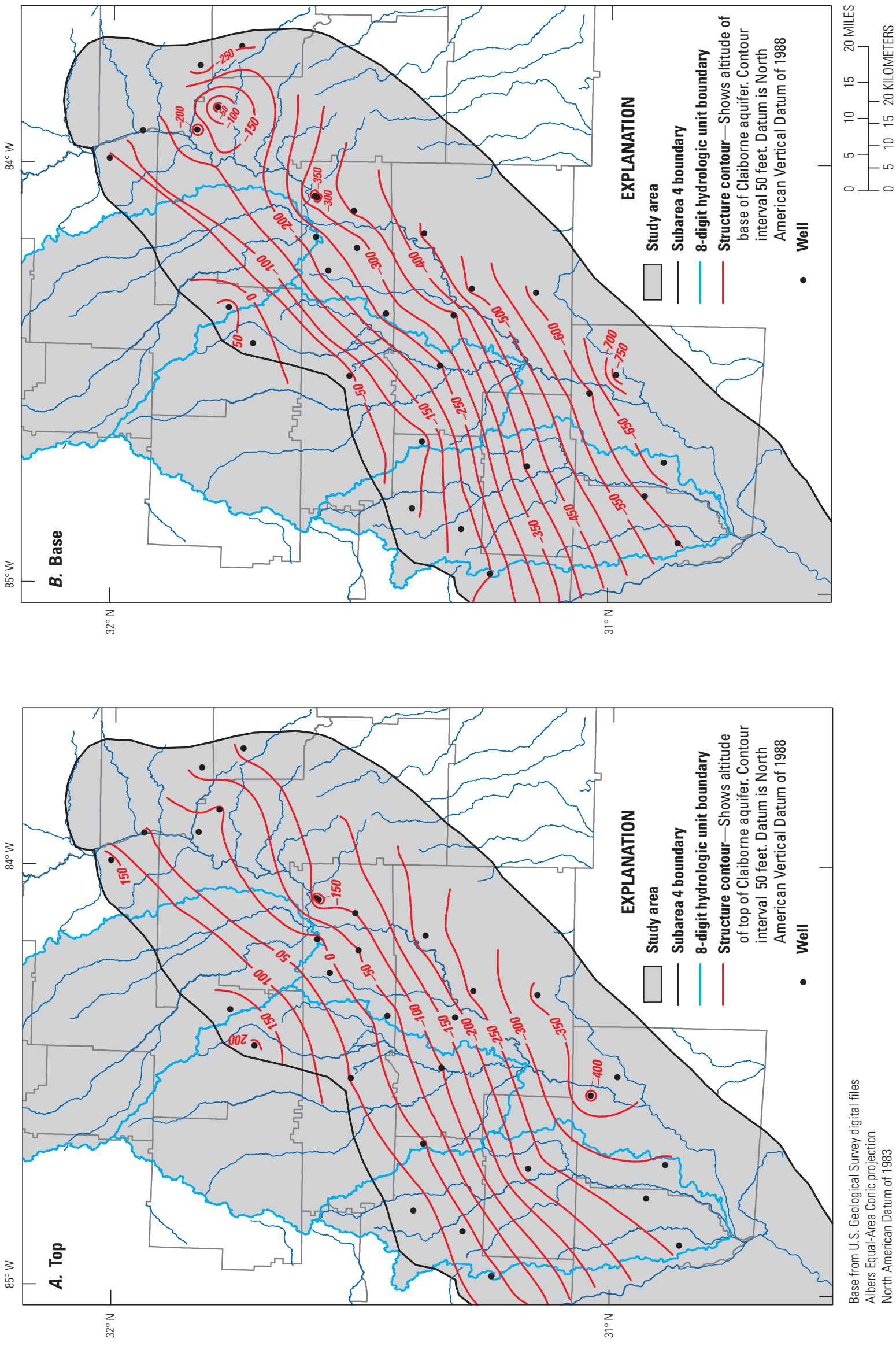

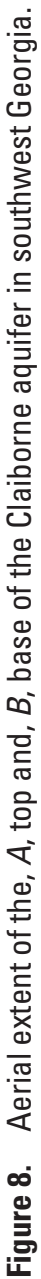




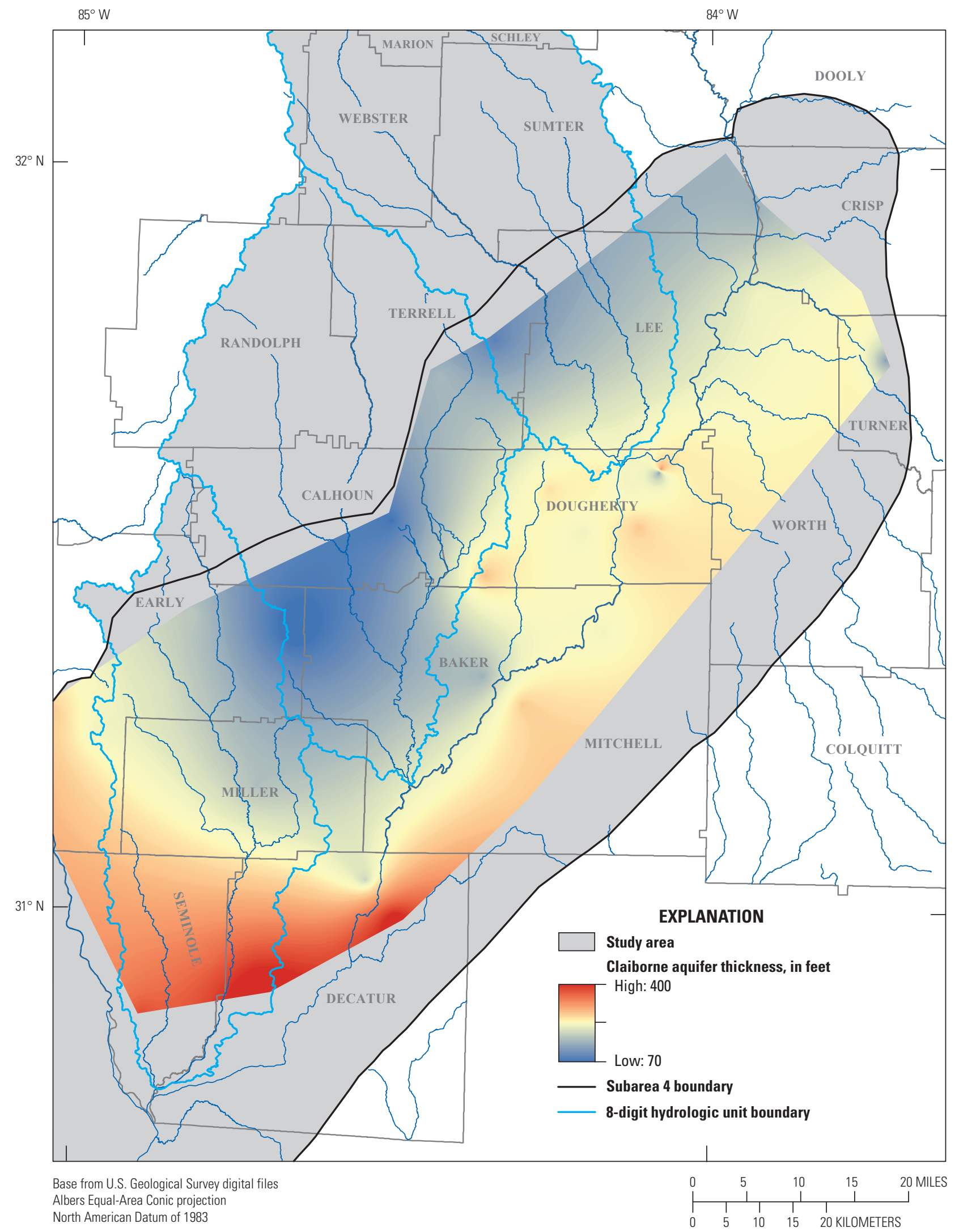

Figure 9. Thickness of the Claiborne aquifer in southwest Georgia. 
Table 2. Well information for wells used to monitor the 72-hour aquifer test, Stripling site, northwest of Camilla, Georgia, December 15-18, 2015.

[NAVD 88, North American Vertical Datum of 1988; —, not pumped]

\begin{tabular}{|c|c|c|c|c|}
\hline Well information & Well 11J029 & Well 11J030 & Well 11J025 & Well 11J011 \\
\hline Land-surface altitude, in feet above NAVD 88 & 162 & 161 & 161 & 163 \\
\hline Distance from pumping well, in feet & 0.33 & 17.8 & 36.3 & 11,780 \\
\hline Well pumped for test? & Yes & No & No & No \\
\hline Top of screen (or open hole), in feet below land surface & ${ }^{1} 460$ & 60 (open hole) & 460 & 397 \\
\hline Bottom of screen (or open hole), in feet below land surface & 700 & 236 & 700 & 417 \\
\hline Aquifer & Claiborne & Upper Floridan & Claiborne & Claiborne \\
\hline Pumping rate $(\mathrm{Q}$, in gallons per minute) & 579 & - & - & - \\
\hline Static water level above NAVD 88 , in feet & 118.7 & 118.22 & 118.71 & 120.11 \\
\hline $\begin{array}{l}\text { Water-level change after 72-hours pumping (from all } \\
\text { influences), in feet }\end{array}$ & 166 & 0.07 & 47.9 & 0.04 \\
\hline $\begin{array}{l}\text { Water level after 72-hours pumping in feet below land } \\
\text { surface, in feet }\end{array}$ & 284.7 & 118.29 & 166.61 & 120.15 \\
\hline
\end{tabular}

${ }^{1}$ Although the screen top is 460 feet below land surface, the outer casing extends to 490 feet below land surface.

meet all of the assumptions of a particular method. Hydraulic properties of the Claiborne aquifer and adjacent confining units were estimated with an axisymmetric, groundwater-flow model using MODFLOW-2005 (Harbaugh, 2005) to simulate water-level change and by comparing the drawdown curves of Claiborne aquifer monitoring well 11J025 to analytical solutions (Theis, 1935; Cooper and Jacob, 1946; Walton, 1962; and Papadopulos and Cooper, 1967).

\section{Water-Level Data}

Continuous and intermittent groundwater-level measurements were made at three of the four aquifer-test wells. Manual, intermittent water-level measurements were made for calibration of groundwater-level recorder readings in monitoring wells $11 \mathrm{~J} 025$ and 11J030. A continuous water-level record was collected in wells 11J025 and 11J030 from November 18 through December 9, 2015, and from about 1 minute prior to the start of the aquifer test on December 15, 2015, until December 21, 2015. A continuous water-level record was collected in wells $11 \mathrm{~J} 025$ and 11 J030 once every hour, except within 24 hours after the beginning and end of the pumping phase of the test when water levels were collected once every minute. Water levels in Claiborne aquifer pumped well 11J029 at the Stripling site were read to the nearest $0.1 \mathrm{ft}$ beginning just before pumping started until about 6 hours after pumping stopped. A continuous water-level record was collected hourly from statewide network well 11J011 and was complete from at least November 1, 2015, to February 1, 2016; these data are available in NWIS. The data used to estimate hydraulic properties of the Claiborne aquifer and its confining units are available in Gordon and Gonthier (2017).

\section{Water-Level Response to Pumping and Drawdown}

Static hydraulic head (namely, the water level inside a tightly-cased well prior to pumping) in the Claiborne and the Upper Floridan aquifers is similar. Prior to pumping on December 15, 2015, the altitude of the hydraulic head in well $11 \mathrm{~J} 029$ was $118.7 \mathrm{ft}$ and in well 11J030 the head was $118.22 \mathrm{ft}$. This small difference in water level indicates a slight hydraulic-head gradient upward from the Claiborne aquifer toward the Upper Floridan aquifer (fig. 4). Pumping from the Claiborne aquifer reverses the hydraulic head gradient at the pumping well, potentially causing leakance from the Upper Floridan into the Claiborne aquifer. A water-level decline in the Upper Floridan aquifer during Claiborne aquifer pumping would indicate leakance from the Upper Floridan into the Claiborne aquifer.

Drawdown response to pumping in the Claiborne aquifer wells (11J029 and 11J025) at the Stripling site were much greater than nonpumping influences in the aquifer (fig. 10). Drawdown in these two wells at a given time was calculated as the measured static water-level altitude in Claiborne aquifer monitoring well $11 \mathrm{~J} 025$ just prior to the start of the aquifer pumping minus the water-level altitude. Drawdown of Upper Floridan aquifer monitoring well 11J030 and distant Claiborne aquifer network well 11J011 in response to the 72-hour aquifer test was estimated using SeriesSEE, a Microsoft Excel add-in (Halford and others, 2012). SeriesSEE was used to filter out the effects of precipitation, barometric pressure, gravity fluctuations (a surrogate for Earth tides), and Flint River stage. Barometric pressure and precipitation data were collected from Albany, Ga., weather station KABY (National Weather Service, 2017); and stage data from the Flint River were collected from USGS streamgage, Flint River at Newton 


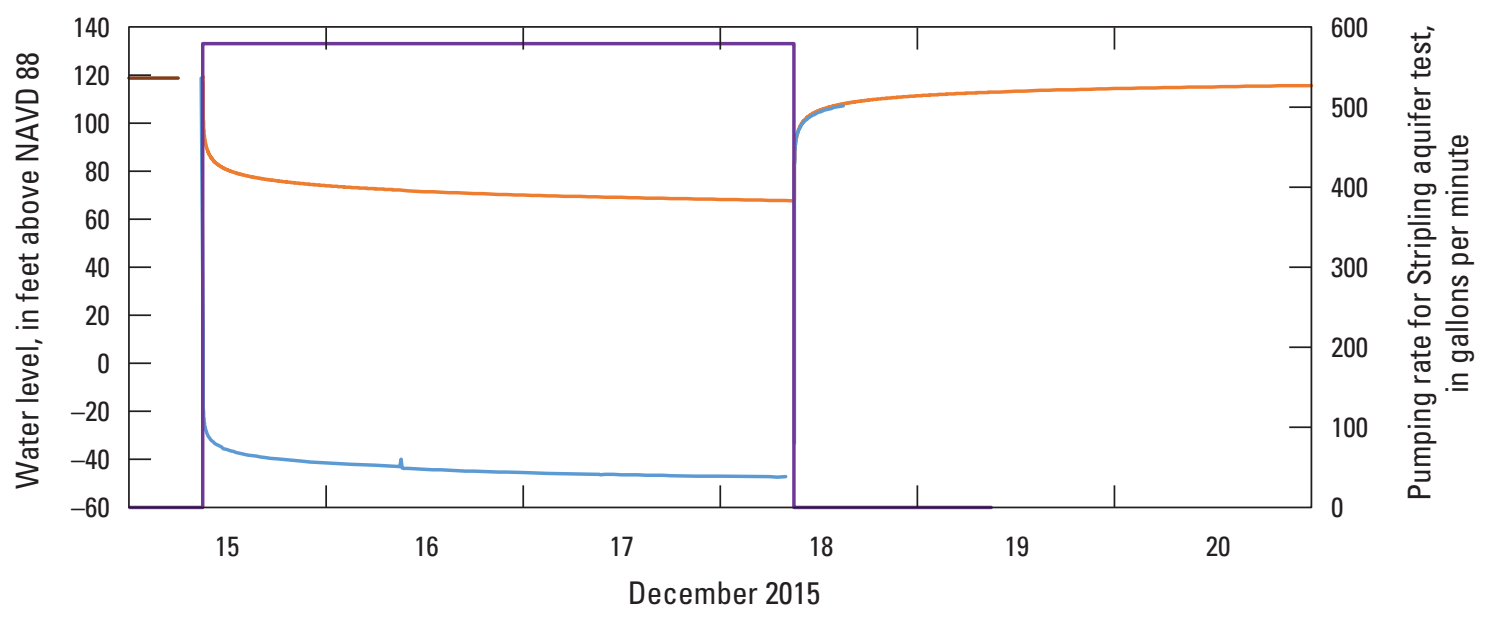

EXPLANATION

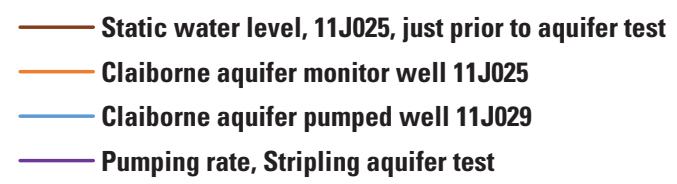

Figure 10. Water-level altitude of Claiborne aquifer wells $11 \mathrm{~J} 025$ and $11 \mathrm{~J} 029$ in response to aquifer-test pumping, Stripling Research site northwest of Camilla, Georgia, December 2015.

02353000 (NWIS; fig. 1). Microgravity time series are produced within SeriesSEE.

Drawdown observations were minimized from hundreds of times to a select few that represent the full dataset (on the order of 20 observations during the pumping phase and 20 observations during the recovery phase). The selected points are spaced fairly evenly on a semi-log plot (figs. 11 and 12). The subset was used in the axisymmetric model.

The two Claiborne aquifer wells at the Stripling site, wells $11 \mathrm{~J} 029$ and $11 \mathrm{~J} 025$, responded to the 72-hour aquifer pumping with tens of feet of drawdown (165.8 and $51.1 \mathrm{ft}$ of maximum drawdown, respectively; figs. 11 and 12). Careful inspection of Upper Floridan aquifer well 11J030 and distant Claiborne aquifer monitoring well, 11J023 using SeriesSEE did not show any drawdown throughout the aquifer pumping at either well. Water levels in these two wells responded to barometric-pressure changes.

The drawdown time series of Claiborne aquifer monitoring well 11J025 on log-log (log drawdown as a function of $\log$ [time]) and semi-log plots (drawdown as a function of $\log$ [time]) exhibits the effects of wellbore storage and aquifer leakage. Observed drawdown of well 11J025 showed minor wellbore storage effects, as indicated by comparison with Theis (fig. 13A) and Papadopulos-Cooper type curves (fig. 13B and $C$ ). As wellbore storage effects abate with time, the observed drawdown for well 11J025 fits the Theis curve, and the slope of the observed drawdown curve on the semilog plot decreased in time through the duration of the 72-hour aquifer test. The data deviate once again from the Theis curve, and the semi-log plot shows a decrease in slope through time, which is characteristic of reaching a recharge boundary, most likely aquifer leakage. While this slope was decreasing, it did not follow the slope of Walton type curves, which decrease to zero (drawdown levels off) in semi-log time. Observed drawdown failing to level off with time might indicate that one or more Walton assumptions have been violated. Unlike the Walton scenario, the aquifer that is contributing water to the Claiborne during pumping is probably experiencing drawdown.

\section{Axisymmetric Model}

Because the drawdown response to pumping indicated aquifer leakage, an axisymmetric model was used to characterize aquifer hydraulic properties. The axisymmetric model grid for the Stripling site consists of 176 rows and 65 columns (fig. 14). Each row represents $5 \mathrm{ft}$ of sediment, for a total thickness of $880 \mathrm{ft}$. The distal edge of the model is set to $200,000 \mathrm{ft}$, which is considered beyond the radius of influence. From left to right, the first four columns represent parts of Claiborne aquifer pumped well 11J029. The fifth column from the left is the first column to represent the hydrogeologic units, and is about $0.03 \mathrm{ft}$ wide. From the sixth column onward toward the right, each column is about 1.269 times wider than the column to its left.

The model is subdivided by rows to characterize six major hydrogeologic units on the basis of lithology (sand, silt, clay, and carbonate sediments). Major hydrogeologic units are represented as 


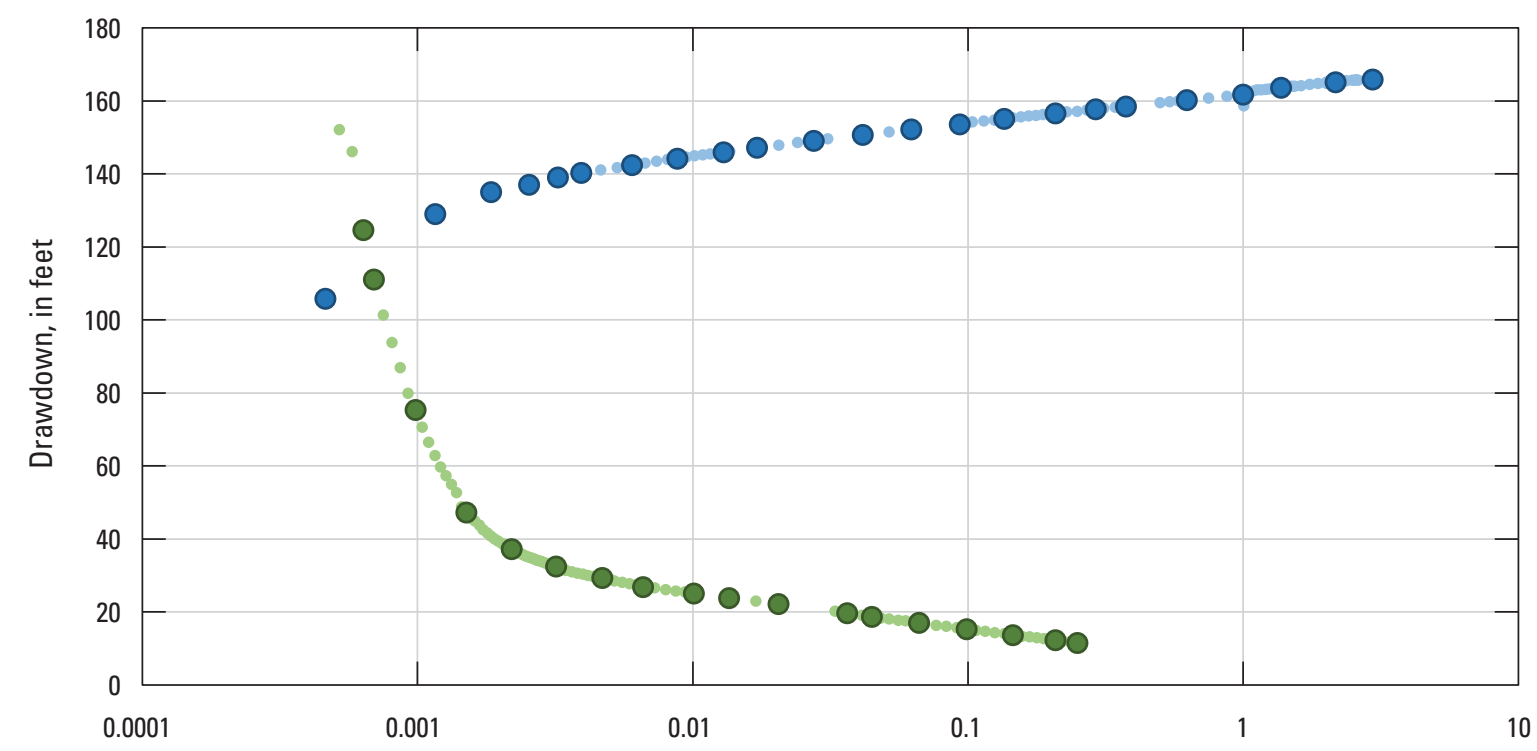

Time after start (pump) or stop (recovery) of aquifer test, in days

EXPLANATION

- Pump O Pump selected - Recovery O Recovery selected

Figure 11. Drawdown observations (total and selected) in Claiborne pumped well 11J029, Stripling Research site, northwest of Camilla, Georgia, December 15-21, 2015.

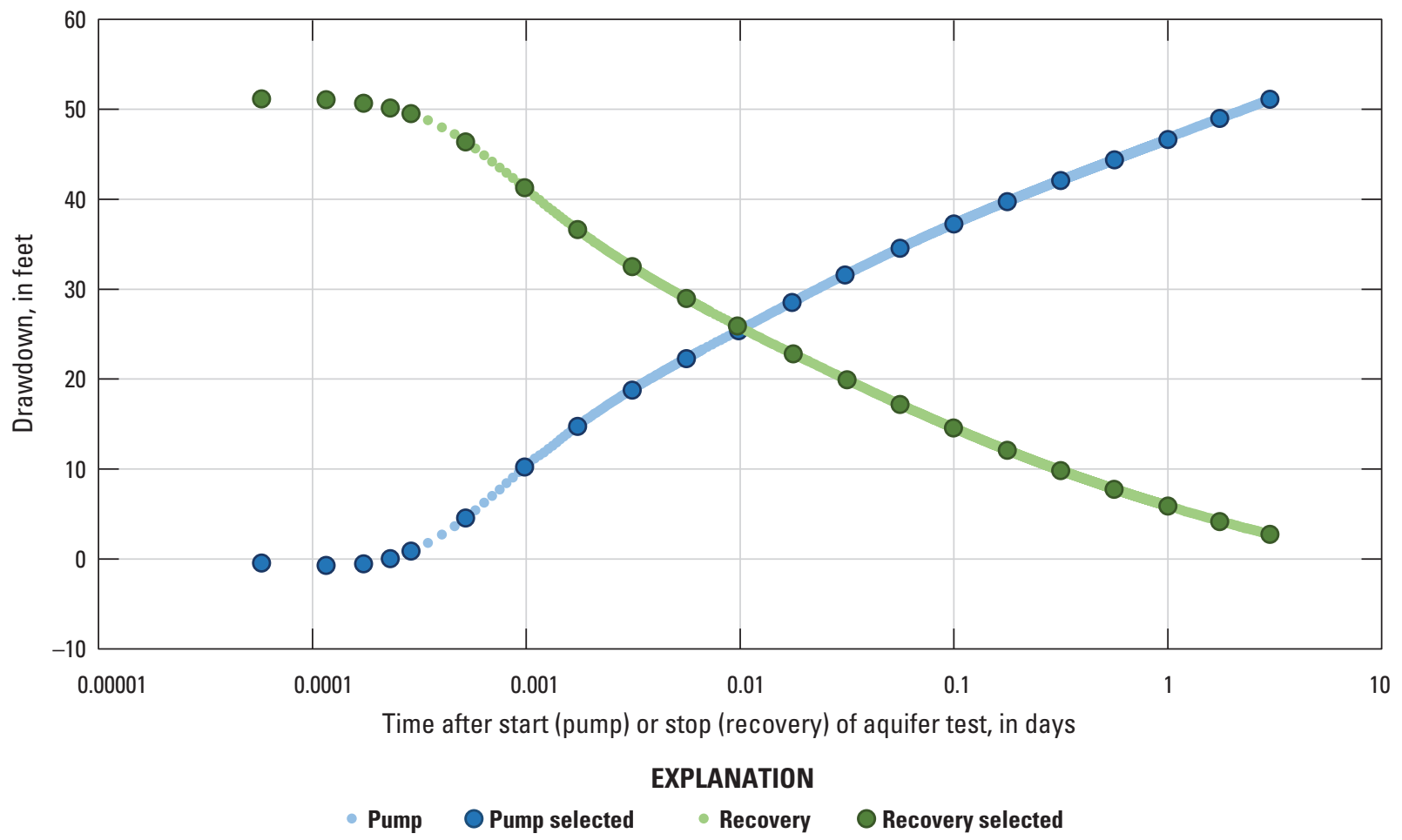

Figure 12. Drawdown observations (total and selected) in Claiborne monitoring well 11J025, Stripling Research site, northwest of Camilla, Georgia, December 15-21, 2015. 

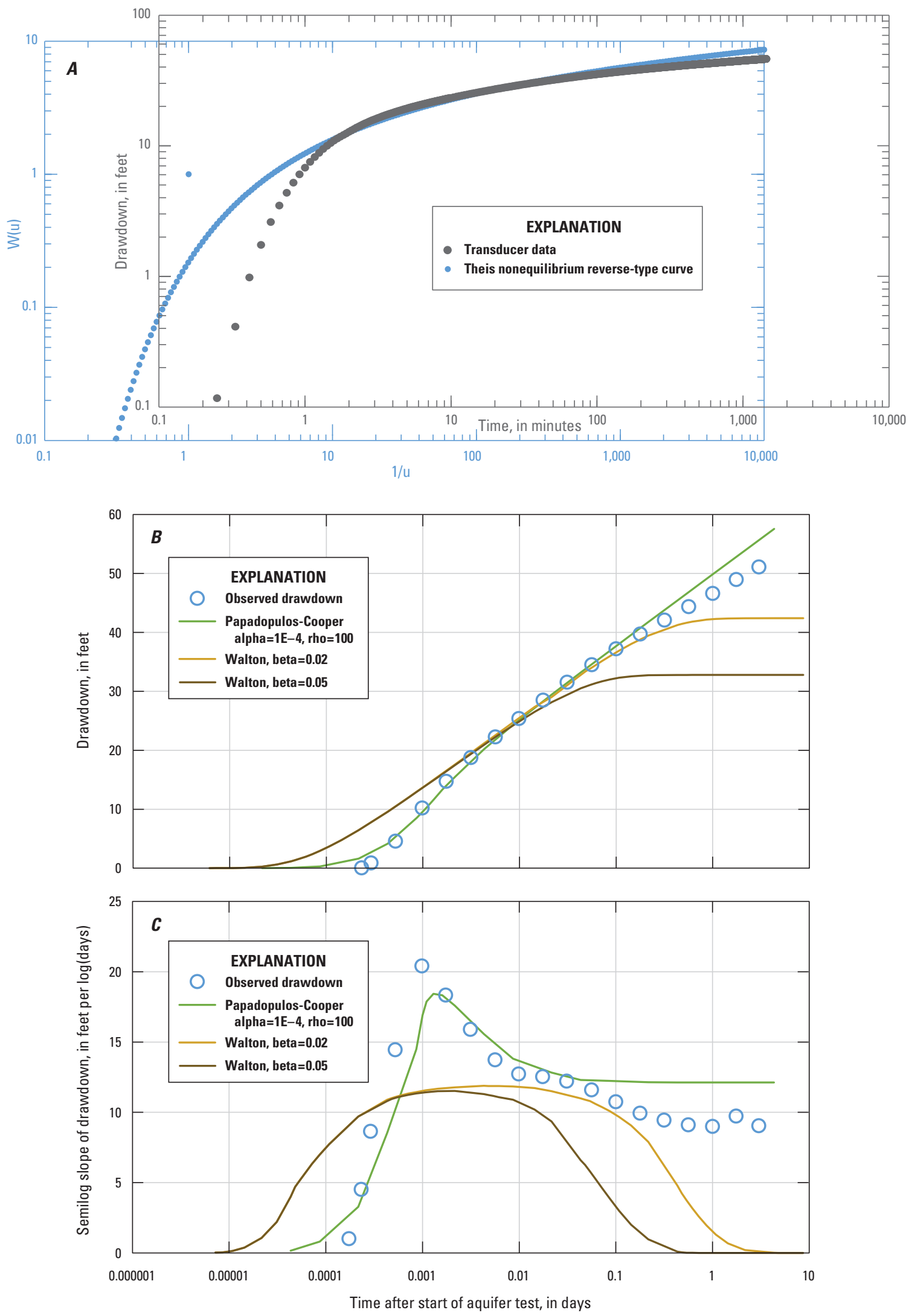

Figure 13. A, Log-log plot of time versus drawdown compared to the Theis curve, and semi-log plots showing, $B$, semi-log drawdown, and $C$, semi-log slope of drawdown of Claiborne aquifer monitoring well 11J025 compared to Papadopulos-Cooper and Walton curves. 


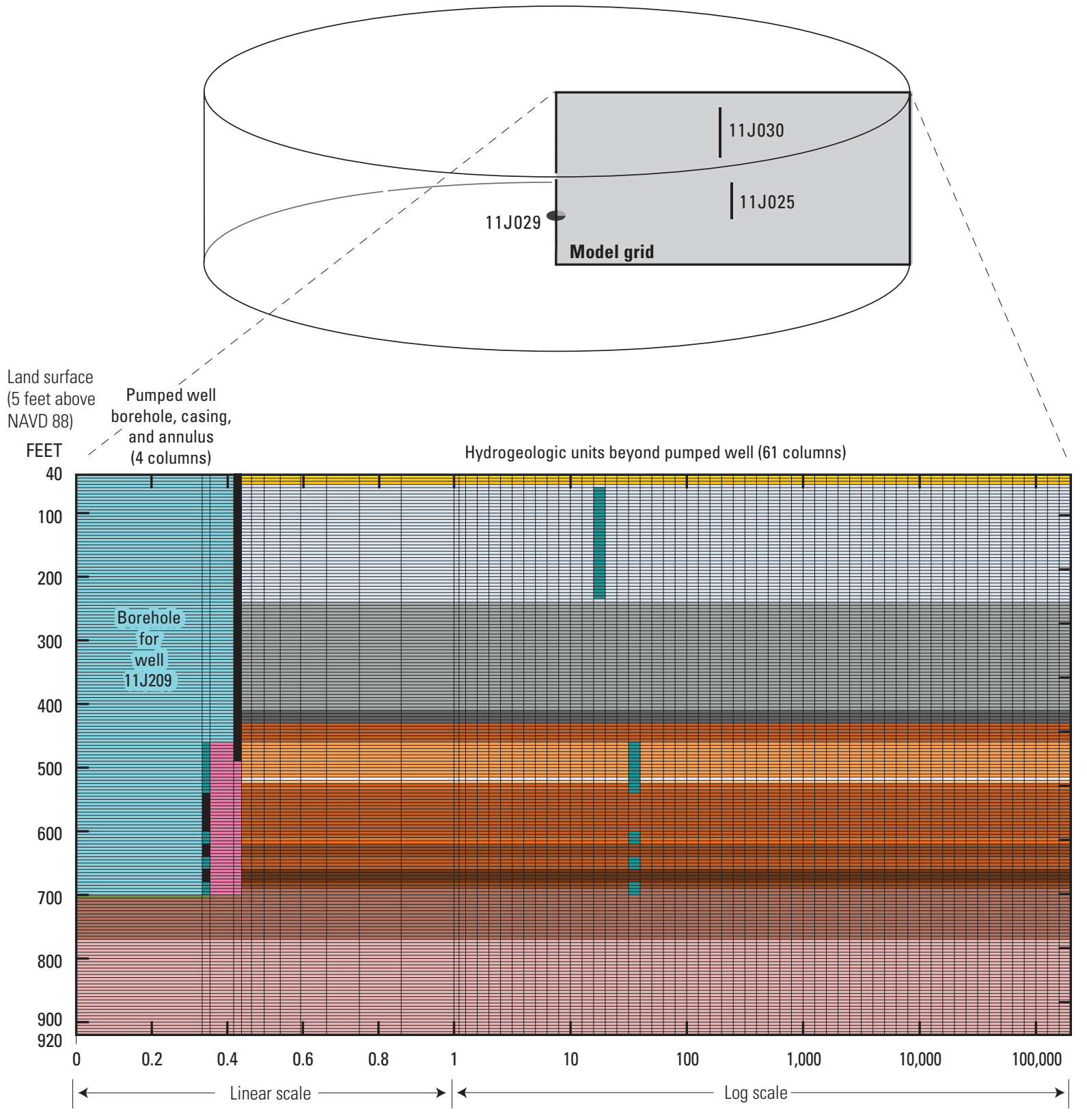

Distance from center of pumped well 11J029, in feet

\section{EXPLANATION}

Well construction

Borehole

Casing (inactive cells)

Annular space

Well opening location

Seal

\section{Hydrogeologic units and numbers}

1 Surficial aquifer (sand), water table

$1 \quad$ Surficial aquifer (sand), confined

2 Upper Floridan aquifer (limestone)

$3 \quad$ Lisbon confining unit (shells and limestone)

$3 \quad$ Lisbon confining unit (silt and limestone)
Claiborne aquifer (sand, silt, and clay)

\begin{tabular}{|c|}
\hline 4 \\
\hline 4 \\
\hline 4 \\
\hline 4 \\
\hline 4 \\
\hline 4 \\
\hline 4 \\
\hline
\end{tabular}

5 Wilcox confining unit (clay)

$6 \quad$ Clayton aquifer (sand)

Figure 14. Axisymmetric model for 72-hour aquifer test at Claiborne well 11J029, Stripling site, northwest of Camilla, Georgia, December 15-18, 2015. 
- unit 1 - sandy sediments near land surface;

- unit 2-the Upper Floridan aquifer, composed of limestone;

- unit 3-the Lisbon Formation confining unit (herein referred to as the "Lisbon confining unit", composed mostly of nonwater-bearing limestone;

- unit 4 - the Claiborne aquifer, composed of sand, shells, silt, clay, and weathered limestone, and variably permeable with depth;

- unit 5-the Wilcox confining unit between the Claiborne and Clayton aquifers (herein referred to as the "Wilcox confining unit", composed of silty clay; and

- unit 6-the Clayton aquifer, composed of sand.

The top row in unit 1 is considered unconfined and represents the water table, with a specific storage of $0.15 \mathrm{ft}^{-1}$. All other rows of the model are assigned the same value of specific storage. Values of hydraulic conductivity are assigned to the Upper Floridan aquifer, Lisbon confining unit, Claiborne aquifer, Wilcox confining unit, and the Clayton aquifer on the basis of lithology and borehole geophysical logging data (fig. 5). The Claiborne aquifer was subdivided into subunits with a value for hydraulic conductivity assigned to each. A value of 20 feet per day (ft/d) was assigned to the Clayton aquifer (not shown in fig. 5).

The model was run with two stress periods that represent (1) drawdown response during the pumping phase of the test and (2) recovery of groundwater levels after the pumping phase of the test. The pumping-phase stress period was represented by 91 time steps totaling 3 days. Time steps ranged from 0.000098 second to 14 hours, 24 minutes, and 2 seconds; and each succeeding time step increased from the previous time step by a multiplier of 1.25 . The recovery stress period is represented by 93 time steps totaling 4 days. Time steps ranged from 0.000084 second to 19 hours, 11 minutes, and 58 seconds; and each succeeding time step increased from the previous time step by a multiplier of 1.25 .

The model simulated the drawdown in response to the 72-hour aquifer pumping. No other influences were simulated so that initial heads and flow within the model were zero. Rather than pumping from the model, water was injected at the same rate that water was withdrawn at the pumped well (579 gal $/ \mathrm{min})$; therefore, simulated increases in water level may be interpreted inversely as drawdown in the pumped well. The water was injected into a cell that represents a part of the wellbore (column 1, row 26) using the MODFLOW WEL package (Harbaugh, 2005). High values for horizontal hydraulic conductivity and specific storage were assigned to the cells representing the wellbore, and lower values were assigned to the cells representing the other parts of the well (table 3).
Simulation of the aquifer pumping using the axisymmetric model involved matching drawdown response in Claiborne aquifer monitoring well 11J025 to pumping at nearby Claiborne aquifer pumped well 11J029. Water levels and therefore drawdown of well 11 J029 could not be verified with manual measurements, so no attempt was made to match simulated drawdown to observed drawdown of the pumped well. Comparisons between simulated and observed drawdown still were made for Claiborne aquifer pumped well 11J029. Simulated drawdown was also noted in the locations of Upper Floridan aquifer monitoring well 11J030 and distant Claiborne aquifer network well 11J011; both wells had no detectable drawdown.

Hydraulic parameters were manually modified in the axisymmetric model to match simulated drawdown to observed drawdown on the graphs. The wellness-of-fit was objectively assessed by using the $R M S$ of the difference between simulated and observed drawdown. Graphs comparing simulated and observed drawdown also were inspected. Root-mean-square of the difference between simulated and observed drawdown, in feet, for different inputs of hydraulic parameters into the aquifer-test model are available in Gordon and Gonthier (2017).

\section{Aquifer Hydraulic Properties}

The two-dimensional, axisymmetric, radial, transient, groundwater-flow model of the 72-hour aquifer test in the Claiborne aquifer at the Stripling site was calibrated using a transmissivity for the Claiborne aquifer of $1,545(1,500) \mathrm{ft}^{2} / \mathrm{d}$, a specific storage for the entire aquifer system of $2.5 \times 10^{-6} \mathrm{ft}^{-1}$, and a vertical hydraulic conductivity $\left(\mathrm{K}_{\mathrm{v}}\right.$ for the Wilcox confining unit of $0.0225(0.02) \mathrm{ft} / \mathrm{d}$. The $2.5 \times 10^{-6} \mathrm{ft}^{-1}$ value for specific storage equates to a storage coefficient for the Claiborne aquifer of $0.000648(0.0006$; the storage coefficient equals specific storage multiplied by aquifer thickness). The values in parentheses are rounded to reflect the accuracy of the method. Simulated drawdown from the calibrated model match observed drawdown of Claiborne aquifer monitoring well 11J025, with only minor discrepancies (table 4, fig. 15A). Even though the model was not calibrated to match observed drawdown in Claiborne aquifer pumped well 11J029, simulated drawdown fit sufficiently to observed drawdown (table 4, fig. 15B). Simulated maximum drawdown at Upper Floridan aquifer monitoring well $11 \mathrm{~J} 030$ was less than $0.01 \mathrm{ft}$; simulated maximum drawdown at distant Claiborne aquifer network well 11J011 was about $0.01 \mathrm{ft}$ (table 4). No drawdown was measured in either of these wells. Model calibration required that the Lisbon confining unit between the Upper Floridan aquifer and the Claiborne aquifer had a low permeability, leading to little or no leakage between the aquifers. As shown in the next section, drawdown in all aquifers was not sensitive to $\mathrm{K}_{\mathrm{x}}$ of the Upper Floridan aquifer. As a result, $\mathrm{K}_{\mathrm{x}}$ of the Upper Floridan could not be estimated. Drawdown in well 11J025 was sensitive to $\mathrm{K}_{\mathrm{v}}$ of the Wilcox confining unit between the Claiborne and Clayton aquifers. The Wilcox 
Table 3. Values of hydraulic parameters used to calibrate the model for the 72-hour aquifer test, Stripling research site, northwest of Camilla, Georgia, December 15-21, 2015.

[ft/d, foot per day; $1 / \mathrm{ft}$, per foot; $\mathrm{ft}$, foot; $\mathrm{P}$, relative permeability number assigned to each subunit of the Claiborne aquifer, based on drillers and geophysical logs; - , not divided into subunits]

\begin{tabular}{|c|c|c|c|c|}
\hline \multirow{2}{*}{ Unit } & \multirow{2}{*}{ Subunit } & \multicolumn{2}{|c|}{ Hydraulic conductivity (ft/d) } & \multirow{2}{*}{$\begin{array}{c}\text { Specific storage } \\
(1 / \mathrm{ft})\end{array}$} \\
\hline & & Horizontal & Vertical & \\
\hline \multirow{2}{*}{ Surficial deposits } & Water table & 10 & 1 & 0.15 \\
\hline & Confined & 10 & 1 & $2.5 \times 10^{-6}$ \\
\hline Upper Floridan aquifer & - & 100 & 15 & $2.5 \times 10^{-6}$ \\
\hline \multirow[t]{2}{*}{ Lisbon confining unit } & Shell and limestone & 0.05 & 0.005 & $2.5 \times 10^{-6}$ \\
\hline & Silt and limestone & 0.05 & 0.005 & $2.5 \times 10^{-6}$ \\
\hline \multirow[t]{12}{*}{ Claiborne aquifer } & $\mathrm{P}=3$ & 5.2667 & 0.527 & $2.5 \times 10^{-6}$ \\
\hline & $\mathrm{P}=5$ & 8.7778 & 0.878 & $2.5 \times 10^{-6}$ \\
\hline & $\mathrm{P}=9$ & 15.8 & 1.58 & $2.5 \times 10^{-6}$ \\
\hline & $\mathrm{P}=6$ & 10.5333 & 1.05 & $2.5 \times 10^{-6}$ \\
\hline & $\mathrm{P}=3$ & 5.2667 & 0.527 & $2.5 \times 10^{-6}$ \\
\hline & $\mathrm{P}=4$ & 7.0222 & 0.702 & $2.5 \times 10^{-6}$ \\
\hline & $\mathrm{P}=3$ & 5.2667 & 0.527 & $2.5 \times 10^{-6}$ \\
\hline & $\mathrm{P}=4$ & 7.0222 & 0.702 & $2.5 \times 10^{-6}$ \\
\hline & $\mathrm{P}=2$ & 3.5111 & 0.351 & $2.5 \times 10^{-6}$ \\
\hline & $\mathrm{P}=3$ & 5.2667 & 0.527 & $2.5 \times 10^{-6}$ \\
\hline & $\mathrm{P}=1$ & 1.7556 & 0.176 & $2.5 \times 10^{-6}$ \\
\hline & $\mathrm{P}=2$ & 3.5111 & 0.351 & $2.5 \times 10^{-6}$ \\
\hline Clayton confining unit & - & 0.45 & 0.0225 & $2.5 \times 10^{-6}$ \\
\hline Clayton aquifer & - & 20 & 2.00 & $2.5 \times 10^{-6}$ \\
\hline
\end{tabular}

\begin{tabular}{|c|c|c|c|}
\hline \multirow{2}{*}{ Well characteristic } & \multicolumn{2}{|c|}{ Hydraulic conductivity (ft/d) } & \multirow{2}{*}{$\begin{array}{c}\text { Specific storage } \\
(1 / \mathrm{ft})\end{array}$} \\
\hline & Horizontal & Vertical & \\
\hline Well bore & $9.0 \times 10^{9}$ & $9.0 \times 10^{9}$ & $5.5 \times 10^{-4}$ \\
\hline Casing & $1.0 \times 10^{-30}$ & $1.0 \times 10^{-30}$ & $1.0 \times 10^{-30}$ \\
\hline Screen & 50 & $2.4 \times 10^{-28}$ & $2.5 \times 10^{-6}$ \\
\hline Annular space & 70 & $2.1 \times 10^{1}$ & $2.5 \times 10^{-6}$ \\
\hline Base at $462.5 \mathrm{ft}$ depth & 70 & $2.4 \times 10^{-28}$ & $2.5 \times 10^{-6}$ \\
\hline Well base at $702.5 \mathrm{ft}$ depth & 0.45 & $2.4 \times 10^{-28}$ & $2.5 \times 10^{-6}$ \\
\hline
\end{tabular}

confining unit $\mathrm{K}_{\mathrm{x}}$ of $0.0225 \mathrm{ft} / \mathrm{d}$ indicates that there may be leakage between these two aquifers. Simulated drawdown in the Clayton unit of the model was about $2.5 \mathrm{ft}$; however, there are no wells open to the Clayton to verify this drawdown.

\section{Sensitivity Analysis}

To assess the viability of model results, a sensitivity analysis of water-level response (drawdown) to changes in Claiborne aquifer transmissivity, Wilcox confining unit vertical hydraulic conductivity $\left(\mathrm{K}_{\mathrm{v}}\right)$, specific storage, Upper Floridan aquifer horizontal hydraulic conductivity $\left(\mathrm{K}_{\mathrm{x}}\right)$, and Lisbon confining unit $\mathrm{K}_{\mathrm{v}}$ was completed (figs. 16-19). Sensitivity of Claiborne aquifer transmissivity, Wilcox confining unit $\mathrm{K}_{\mathrm{v}}$, and specific storage of all hydrogeologic units to simulated drawdown was determined at Claiborne aquifer monitoring well 11J025. No drawdown was detected in the Upper Floridan monitoring well 11J030, so the observed drawdown is assumed to be zero for this well. Sensitivity of the Upper Floridan aquifer $\mathrm{K}_{\mathrm{x}}$ and Lisbon confining unit $\mathrm{K}_{\mathrm{v}}$ to simulated drawdown was determined at Upper Floridan aquifer monitoring well 11J030 and Claiborne aquifer monitoring well 11J025. Although simulated drawdown was not calibrated to 
Table 4. Summary of 72-hour aquifer test results, Stripling research site, northwest of Camilla, Georgia, December 15-18, 2015.

[ft, foot; $\mathrm{ft}^{2} / \mathrm{d}$, foot squared per day; n.d., not detected]

\begin{tabular}{|c|c|c|c|c|}
\hline \multirow{2}{*}{$\begin{array}{l}\text { USGS } \\
\text { well } \\
\text { identifier }\end{array}$} & \multirow[b]{2}{*}{ Hydrogeologic unit } & \multirow{2}{*}{$\begin{array}{l}\text { Distance from } \\
\text { center of pumping } \\
\text { (ft) }\end{array}$} & \multicolumn{2}{|c|}{ Maximum drawdown (ft) } \\
\hline & & & Observed & $\begin{array}{c}\text { Simulated, } \\
\text { calibrated model }\end{array}$ \\
\hline $11 \mathrm{~J} 029$ & Claiborne aquifer & 0.33 & 165.8 & 162.0 \\
\hline $11 \mathrm{~J} 030$ & Upper Floridan aquifer & 17.75 & n.d. & 0.007 \\
\hline $11 \mathrm{~J} 025$ & Claiborne aquifer & 36.30 & 51.1 & 51.5 \\
\hline $11 \mathrm{~J} 011$ & Claiborne aquifer & $11,780.00$ & n.d. & 0.01 \\
\hline
\end{tabular}

Calibrated transmissivity: $1,500 \mathrm{ft}^{2} / \mathrm{d}$

Calibrated storage coefficient: 0.0006

observed drawdown of Claiborne aquifer pumped well 11J029, results for this well are included in the sensitivity analysis.

The sensitivity analysis consisted of 43 model runs, whereby one or two tested parameters were adjusted during a specific run while all other parameter values were assigned the values used in the calibrated model (tables 3 and 4). The $R M S$ value of each model run was compared to the $R M S$ value of the calibrated model run.

Simulated drawdown at Claiborne aquifer monitoring well 11J025 is sensitive to both changes in Claiborne aquifer transmissivity and Wilcox confining unit $\mathrm{K}_{\mathrm{v}}$ (fig. 16).

Claiborne aquifer transmissivity was modified to determine the best fit of simulated to observed drawdown in Claiborne aquifer monitoring well 11 J025 for values of Claiborne confining unit $\mathrm{K}_{\mathrm{v}}$ of $0.0025,0.015,0.0225,0.03$, and $0.075 \mathrm{ft} / \mathrm{d}$ (fig. 16). The larger the value of Claiborne confining unit $\mathrm{K}_{\mathrm{v}}$, the lower the Claiborne aquifer transmissivity that creates the best fit for that value of Wilcox confining unit $\mathrm{K}_{\mathrm{v}}$. Best fit values of Claiborne aquifer transmissivity ranged from 1,418 ft' $/ \mathrm{d}$ for a Wilcox confining unit $\mathrm{K}_{\mathrm{v}}$ value of $0.075 \mathrm{ft} / \mathrm{d}$ to $1,662 \mathrm{ft}^{2} / \mathrm{d}$ for a Claiborne confining unit $\mathrm{K}_{\mathrm{v}}$ value of $0.0025 \mathrm{ft} / \mathrm{d}$. The best fit for both Claiborne aquifer transmissivity and Claiborne confining unit $\mathrm{K}_{\mathrm{v}}$ is $1,545 \mathrm{ft}^{2} / \mathrm{d}$ and $0.0225 \mathrm{ft} / \mathrm{d}$, respectively (fig. 16).

Simulated drawdown was sensitive to changes in a single value of specific storage assigned to all hydrogeologic units (fig. 17). The best fit to observed drawdown at Claiborne aquifer monitoring well $11 \mathrm{~J} 025$ was with a specific storage value of $2.5 \times 10^{-6} \mathrm{ft}^{-1}$ (fig. 17). Higher values of specific storage are associated with depressed values of simulated drawdown at Upper Floridan aquifer well 11J030.

Simulated drawdown in the Claiborne aquifer was not sensitive to changes in Upper Floridan aquifer $\mathrm{K}_{\mathrm{x}}$ values from 17 to $100 \mathrm{ft} / \mathrm{d}$. Almost no change in $R M S$ is apparent in Claiborne aquifer wells 11J029 and 11J025. Higher values of Upper Floridan $\mathrm{K}_{\mathrm{x}}$ are associated with depressed values of simulated drawdown (and therefore depressed values of $R M S$ ) at Upper Floridan monitoring well 11J030 (fig. 18).
Simulated drawdown was sensitive to changes in Lisbon confining unit $\mathrm{K}_{\mathrm{v}}$ values that range from 0.007 to $0.192 \mathrm{ft} / \mathrm{d}$ (fig. 19). The best fit for all three wells was with the minimum Lisbon confining unit $\mathrm{K}_{\mathrm{v}}$ value tested $(0.007 \mathrm{ft} / \mathrm{d})$. Simulated drawdown in Upper Floridan monitoring well 11J030 more closely matched the observed drawdown (no detected drawdown) with an Upper Floridan aquifer $\mathrm{K}_{\mathrm{x}}$ value of $100 \mathrm{ft} / \mathrm{d}$ than with $41 \mathrm{ft} / \mathrm{d}$, for all values of Lisbon confining unit $\mathrm{K}_{\mathrm{v}}$, because the values are closer to zero.

\section{Newberry Aquifer Test}

To determine the hydraulic properties of the Claiborne aquifer at the Newberry site, Claiborne aquifer well $08 \mathrm{~K} 026$ was pumped at an average rate of $291 \mathrm{gal} / \mathrm{min}$ beginning at 1:30:00 p.m. on March 14, 2016, for 72 hours and 5 seconds until 1:30:05 p.m. on March 17, 2016. Water levels in well $08 \mathrm{~K} 026$ and two other wells (08K025 and 08K001) were monitored during the aquifer test (fig. 20). Wells $08 \mathrm{~K} 025$ and 08K026 are screened in the Claiborne aquifer from 215 to about $290 \mathrm{ft}$ below land surface. Claiborne monitoring well $08 \mathrm{~K} 025$ is located $201 \mathrm{ft}$ from the pumped well. Well 08K001 is a statewide network well located $84 \mathrm{ft}$ from the pumped well and is open from 61 to $125 \mathrm{ft}$ below land surface within the Upper Floridan aquifer. Well construction information for all wells used during the aquifer test at the Newberry site is listed in table 5.

The Claiborne aquifer at this site demonstrated slow recovery after pumping rates were tested prior to the ultimate 72-hour aquifer test. These prior tests were conducted to determine the optimal pumping rate for the 72-hour aquifer test. Prior tests included a preliminary evaluation of the pump rate conducted on January 28, 2016, when the well was pumped for 2 hours at $460 \mathrm{gal} / \mathrm{min}$, which was too high a rate for the well to sustain for 72 hours without water levels falling below the pump and below the top of the aquifer; a second evaluation of the pump rate occurred on March 10, 2016, 4 days prior to the 72-hour aquifer test. On March 10, the well was pumped from 12:42 to 1:12 p.m. and from 2:21 to 5:57 p.m. 

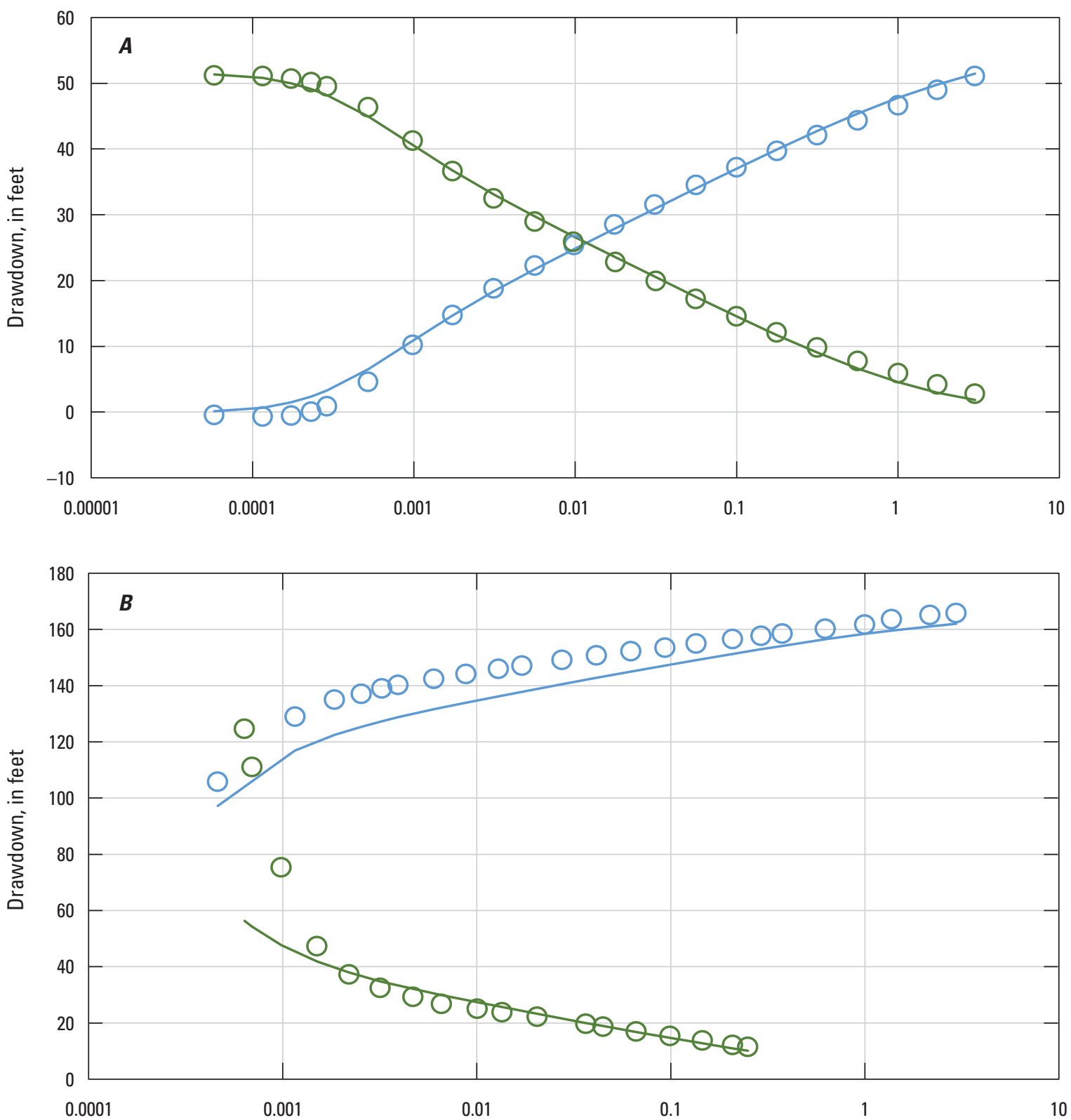

Time after start (pump) or stop (recovery) of aquifer test, in days

EPLANATION

Observed drawdown during pumping

C_imulated drawdown during pumping

O Observed drawdown recovery

- Simulated drawdown during recovery

Figure 15. Comparison of simulated and observed drawdown for calibrated two-dimensional, axisymmetric, radial, transient, groundwater-flow model of 72-hour aquifer test at two Claiborne aquifer wells, Stripling Research site, northwest of Camilla, Georgia, December 15-21, 2015. A, monitoring well 11J025, B, pumped well 11J029. 


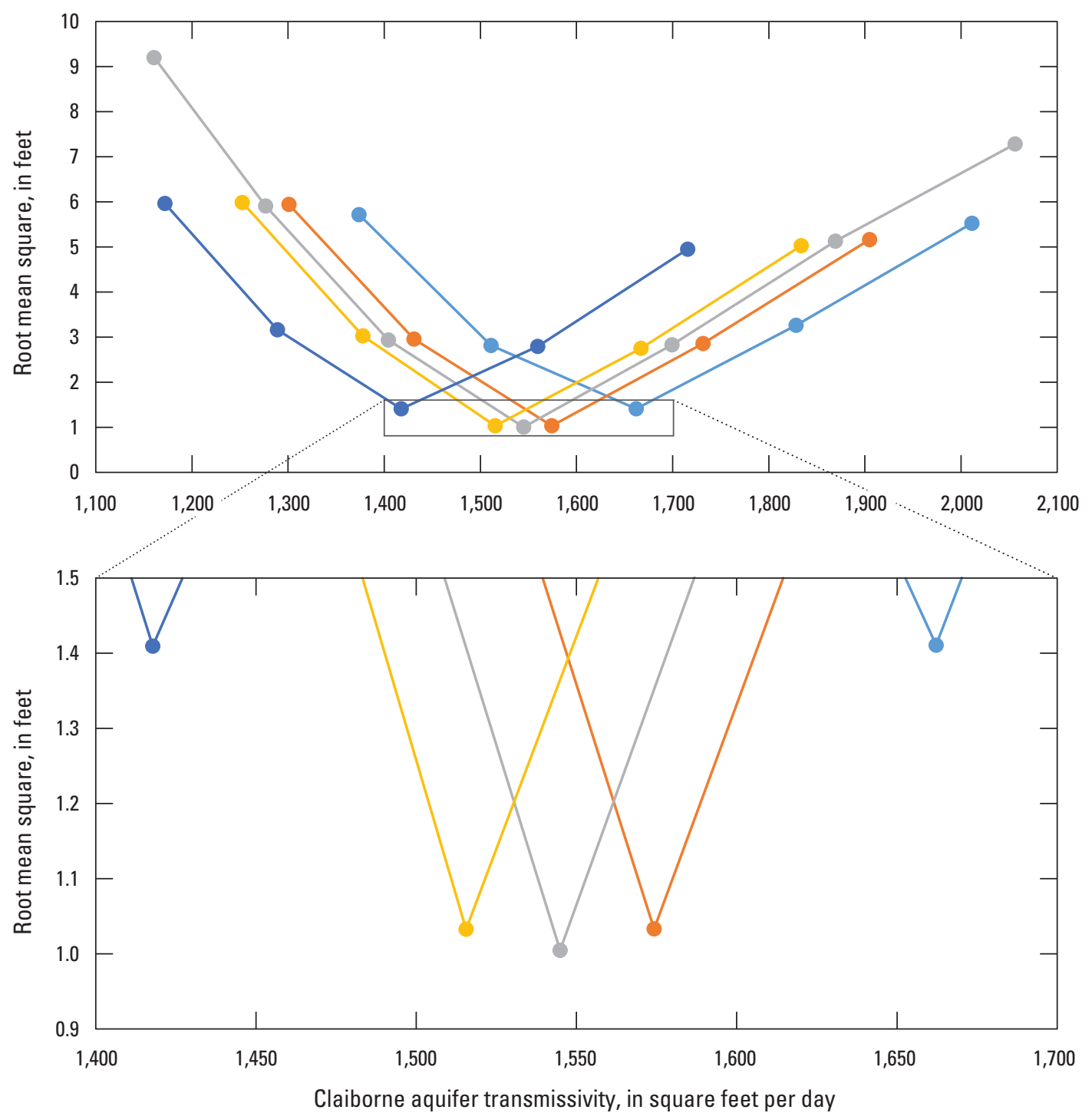

EXPLANATION

Vertical hydraulic conductivity of the Clayton confining unit, in feet per day

$\longrightarrow 0.0025 \multimap 0.015 \multimap 0.0225 \multimap 0.03 \multimap 0.075$

Figure 16. Root mean square of the difference between simulated and observed drawdown in Claiborne aquifer monitoring well 11J025, for different values of Claiborne aquifer transmissivity and vertical hydraulic conductivity of the confining unit between the Clayton and Claiborne aquifers, Stripling Research site aquifer test, December 15-21, 2015.

at $300 \mathrm{gal} / \mathrm{min}$, which resulted in a sustainable drawdown. The aquifer test began at 1:30 p.m. on March 14, 2016, with the pump running for 72 hours at a rate of $290 \mathrm{gal} / \mathrm{min}$. Hydraulic properties of the Claiborne aquifer were estimated using traditional, analytical solutions and temporal superposition (Theis, 1935; Ferris and others, 1962; Reilly and others, 1984; and Keith J. Halford, U.S. Geological Survey, written commun., 2010).

Continuous and intermittent groundwater-level measurements were made at the three aquifer-test wells. A continuous water-level record was collected from Claiborne aquifer pumped well 08K026 during January 25-27, 2016, and 43 days later, from March 10 to April 4, 2016. Frequent manual water-level measurements allowed the water-level record at the pumped well to extend from January 27 to the morning of January 29, 2016, shortening the data gap to 41 days. A continuous water-level record was collected from Claiborne aquifer monitoring well 08K025 and Upper Floridan aquifer statewide network well 08K001 from December 30, 2015, to April 4, 2016. During the 72-hour aquifer test, a continuous water-level record was collected in the three wells used for the test, $08 \mathrm{~K} 001,08 \mathrm{~K} 025$, and $08 \mathrm{~K} 026$, every 5 seconds just after the start and end of pumping and with 


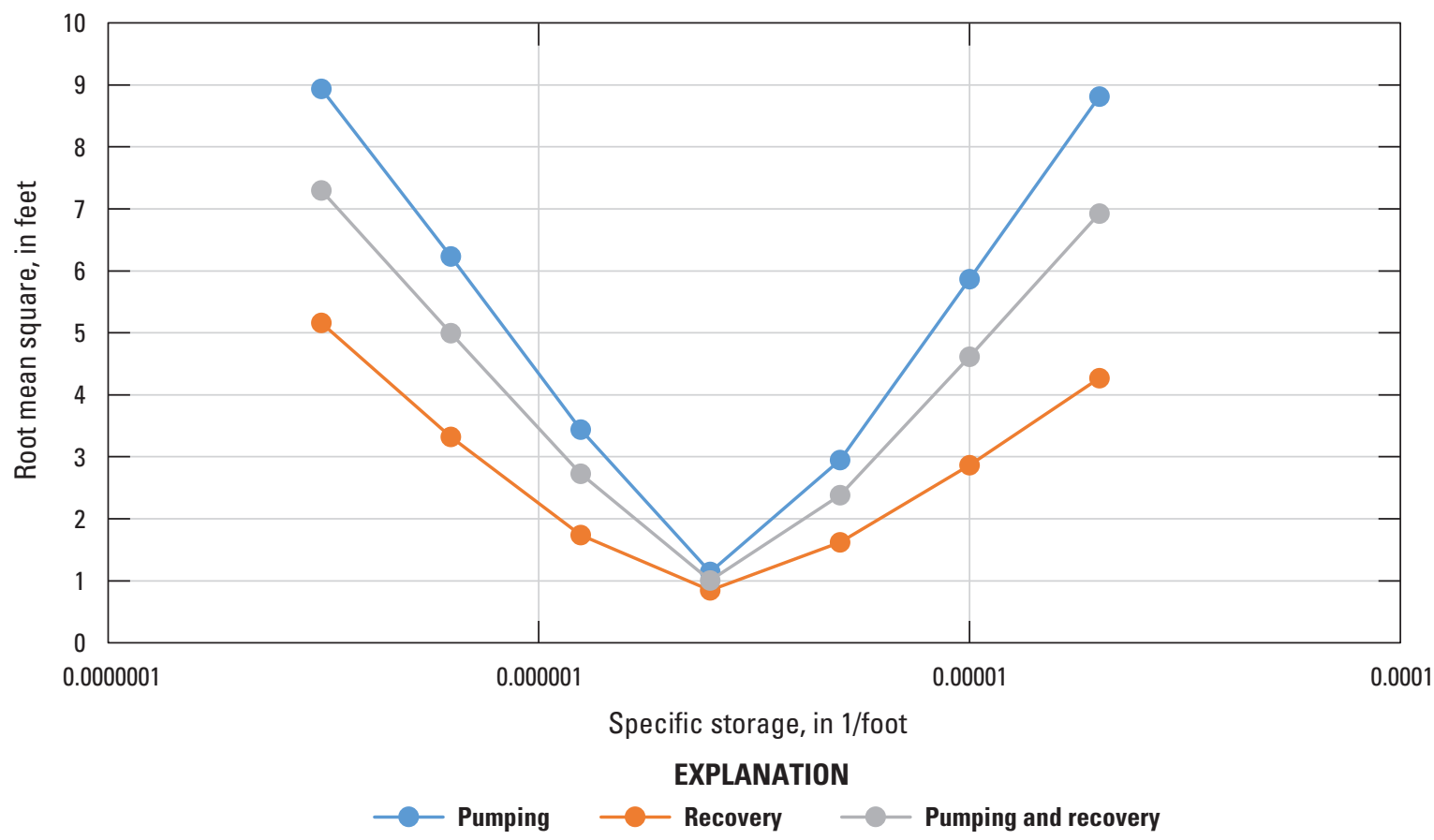

Figure 17. Root mean square of the difference between simulated and observed drawdown for different values of specific storage in the confined groundwater system, Claiborne aquifer monitoring well 11J025, Stripling Research site aquifer test, December 15-21, 2015.

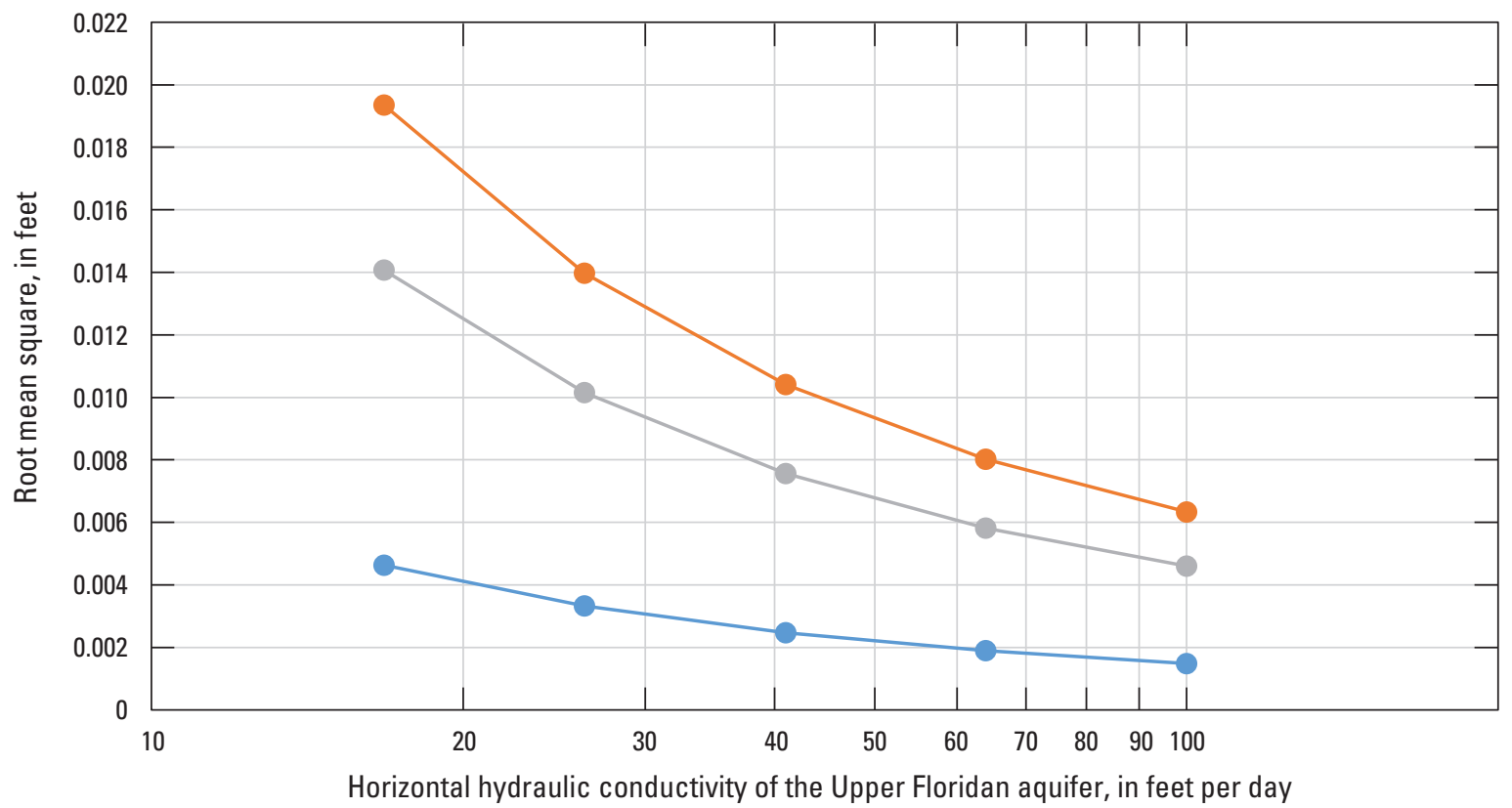

EXPLANATION

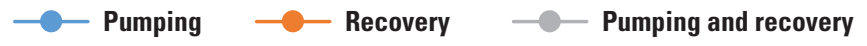

Figure 18. Root mean square of the difference between simulated and observed drawdown in Upper Floridan monitoring well 11 J030, for different values of horizontal hydraulic conductivity in the Upper Floridan aquifer, Stripling Research site aquifer test, December 15-21, 2015. 
Figure 19. Root mean square of the difference between simulated and observed drawdown for different values of horizontal hydraulic conductivity in the Upper Floridan aquifer and vertical hydraulic conductivity in the Lisbon confining unit, Stripling Research site aquifer test, December 15-21, 2015. $A$, Claiborne pumped well 11J025, $B$, Claiborne monitoring well 11J029, and $C$, Upper Floridan monitoring well $11 \mathrm{~J} 030$.
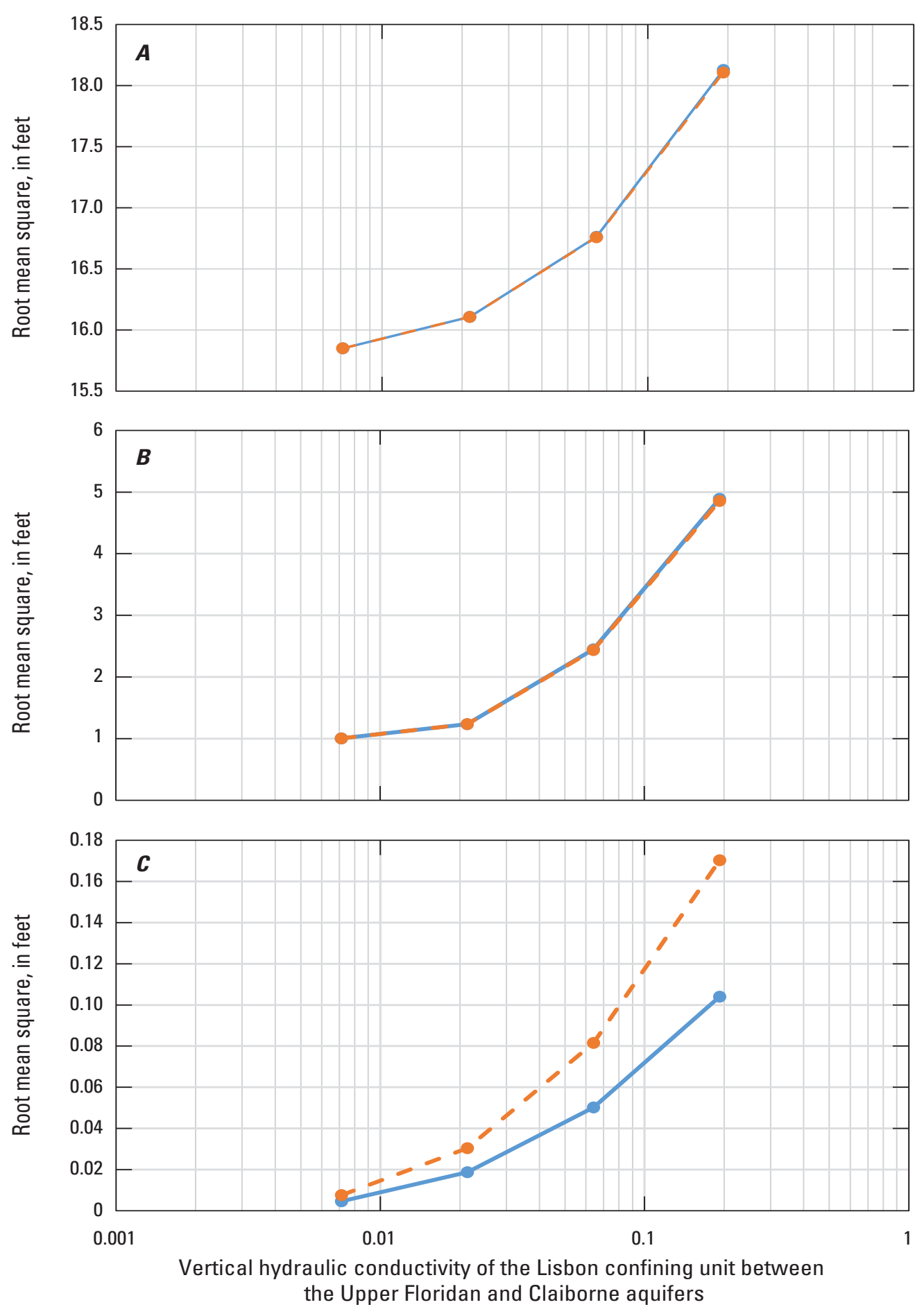

EXPLANATION

Horizontal hydraulic conductivity in the Upper Floridan aquifer, in feet per day 
A
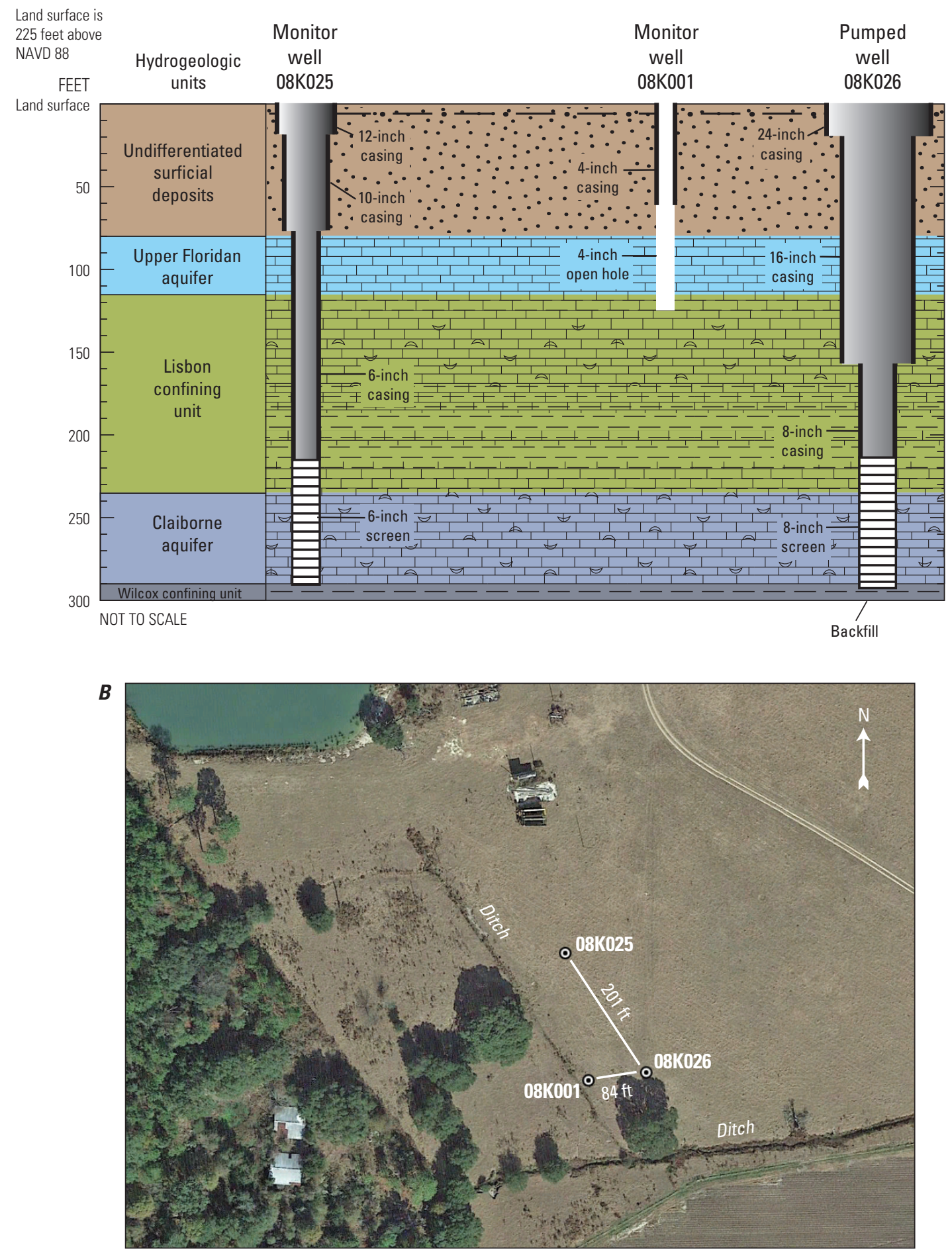

Imagery (2016 Google, Map data (2016 Google

Figure 20. $A$, Well construction and, $B$, layout used in a 72-hour aquifer test, Newberry site, northeast Early County, southeast of Arlington, Georgia, December 15-18, 2015. 
Table 5. Well construction information for wells used to monitor the 72-hour aquifer test, Newberry site, northeast Early County, southeast of Arlington, Georgia, December 15-18, 2015.

[NAVD 88, North American Vertical Datum of 1988]

\begin{tabular}{lccc}
\hline \multicolumn{1}{c}{ Well information } & Well 08K026 & Well 08K025 & Well 08K001 \\
\hline Land-surface altitude, in feet above NAVD 88 & 222.2 & 223.19 & 221.26 \\
Distance from aquifer test pumping, in feet & 0.3333 & 201 & 84 \\
Well pumped for aquifer test? & Yes & No & No \\
Top of opening, in feet below land surface & 215 & 215 & 61 \\
Bottom of opening, in feet below land surface & 295 & 290 & 125 \\
Type of opening & Screen & Screen & Open hole \\
Aquifer & Claiborne & Claiborne & Upper Floridan \\
\hline
\end{tabular}

decreasing frequency thereafter until measurements were recorded once every minute until the end of each phase of the test. The data used to estimate hydraulic properties of the Claiborne aquifer and its confining units are available in Gordon and Gonthier (2017).

\section{Water-Level Response to Pumping and Drawdown}

Water-level data from Claiborne monitoring (08K025, fig. 21) and production (08K026, fig. 22) wells indicate a consistent, long-term, second-order trend through the period of record, from December 30, 2015, to April 4, 2016. Superimposed on this long-term trend is a slow water-level recovery from the pumping events. Continuous water-level data for well $08 \mathrm{~K} 025$, prior to the first attempted aquifer test (from December 30, 2015, to January 27, 2016) and just prior to pump rate tests before the aquifer test (from about March 2 to $9,2016)$ were used to create a "background line" that represents the approximate water-level altitude with no pumping influence. The background line was specified by the following equation:

$$
B L_{w, t}=\left(-0.00042\left[t-t_{0}\right]^{2}\right)+\left(0.067\left[t-t_{0}\right]\right)+O_{w},
$$

where

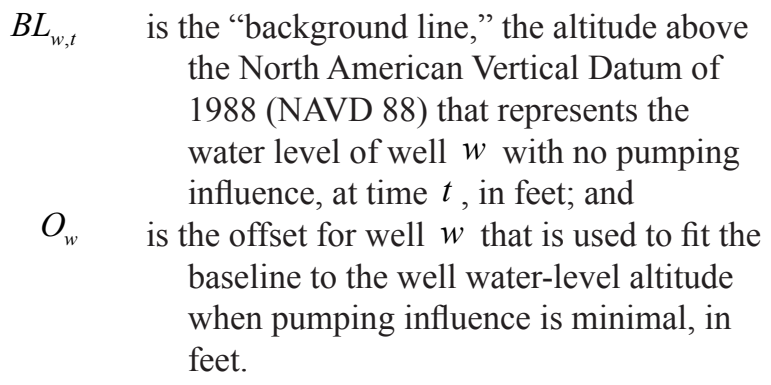

The $O_{w}$ for wells $08 \mathrm{~K} 025$ and $08 \mathrm{~K} 026$ was 200.45 and $199.37 \mathrm{ft}$, respectively. The "long-term drawdown" in response to multiple pumping events is the altitude of the background line, minus the water-level altitude in well 08K025 (fig. 23) and 08K026 (fig. 24). Water-level fluctuations caused by nonpumping influences were as great as $0.25 \mathrm{ft}$.

At the beginning of the 72-hour aquifer test on March 14, water levels in Claiborne aquifer wells $08 \mathrm{~K} 025$ and $08 \mathrm{~K} 026$ still had not fully recovered from pumping on March 10 and were 0.3 and $0.4 \mathrm{ft}$, below static levels, respectively. The drawdown in response to the 72-hour test during March 14-17 was estimated for each of the two Claiborne aquifer wells using Theis concepts and superposition. The drawdown between the March 10 pump rate tests and the 72-hour aquifer test was simulated using SUMTheis (Keith J. Halford, U.S. Geological Survey, written commun., 2010). Parameters that were adjusted to simulate the long-term drawdown for each of the two wells were transmissivity, the storage coefficient, the time of the pump shutoff at the end of the last pumping event on March 10, and an offset. The simulated long-term drawdown was then extended past the start of the aquifer test without the test pumping. The extended curve led to a continued recovery curve that can be taken as the baseline reference for drawdown. Drawdown specific to the 72-hour pumping was then equal to the long-term drawdown minus the continued simulated recovery curve (fig. 25).

Water levels in Upper Floridan aquifer monitoring well 08K001 did not indicate a detected drawdown response to pump rate tests (fig. 26). The main nonpumping influence on the water level in well 08K001 was rainfall. The water-level altitude was simulated by adding recharge from rainfall on an hourly basis, thereby increasing the water level. The rainfall's influence on simulated water level exponentially decays with time, similar to the precipitation index by Kosugi and others (2008). The water-level altitude in well 08K001 does appear to spike about $0.04 \mathrm{ft}$ during the pump rate tests on March 10 and at the start of the pumping phase of the aquifer test (closeup of March 10 spikes are shown on fig. 26B). These spikes most likely are caused by the direct recharge of pumped water from 08K026.

Drawdown observations were minimized from hundreds to approximately 35 that represent the full dataset during the pumping and recovery phases for wells $08 \mathrm{~K} 026$ and $08 \mathrm{~K} 025$ (figs. 27 and 28). The selected points are spaced fairly evenly on the semi-log plots. The time between each succeeding 

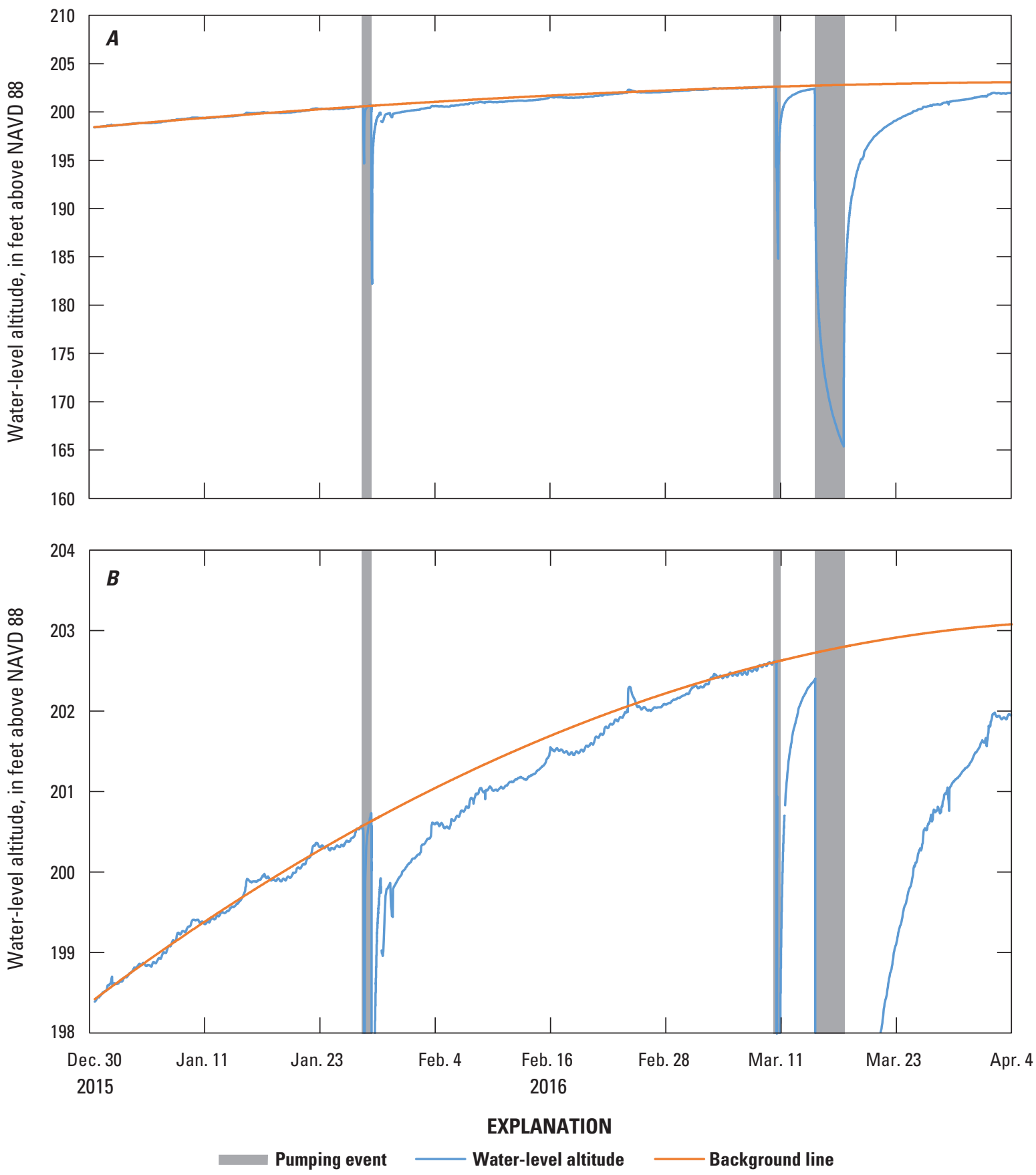

Figure 21. Water-level altitude and background line, Claiborne aquifer monitoring well 08K025, Newberry site, northeast Early County, southeast of Arlington, Georgia, December 30, 2015 - April 4, 2016 ( $A$ has a broad vertical scale, $B$ has a close-up vertical scale).

interval for selected drawdown observations increased by a factor of about 1.45 for each of the two Claiborne wells $08 \mathrm{~K} 026$ and $08 \mathrm{~K} 025$. The drawdown data were culled to expedite the simulation process using SUMTheis and to avoid using spurious data during the recovery phase of pumped well 08K026 (fig. 27B).

Water levels in the two Claiborne aquifer wells at the Newberry site, wells $08 \mathrm{~K} 026$ and $08 \mathrm{~K} 025$, responded to the 72-hour aquifer test with tens of feet of drawdown (105.0 and $37.1 \mathrm{ft}$, respectively; figs. 29 and 30). The drawdown time series of Claiborne aquifer wells $08 \mathrm{~K} 026$ and $08 \mathrm{~K} 025$ exhibit the effects of the aquifer-test withdrawal reaching a restrictedflow or no-flow boundary. The drawdown in pumped well 08K026 closely follows Papadopulos-Cooper curves during the first 2 minutes, suggesting wellbore storage. As wellbore storage effects abate, drawdown in well $08 \mathrm{~K} 026$ continues 

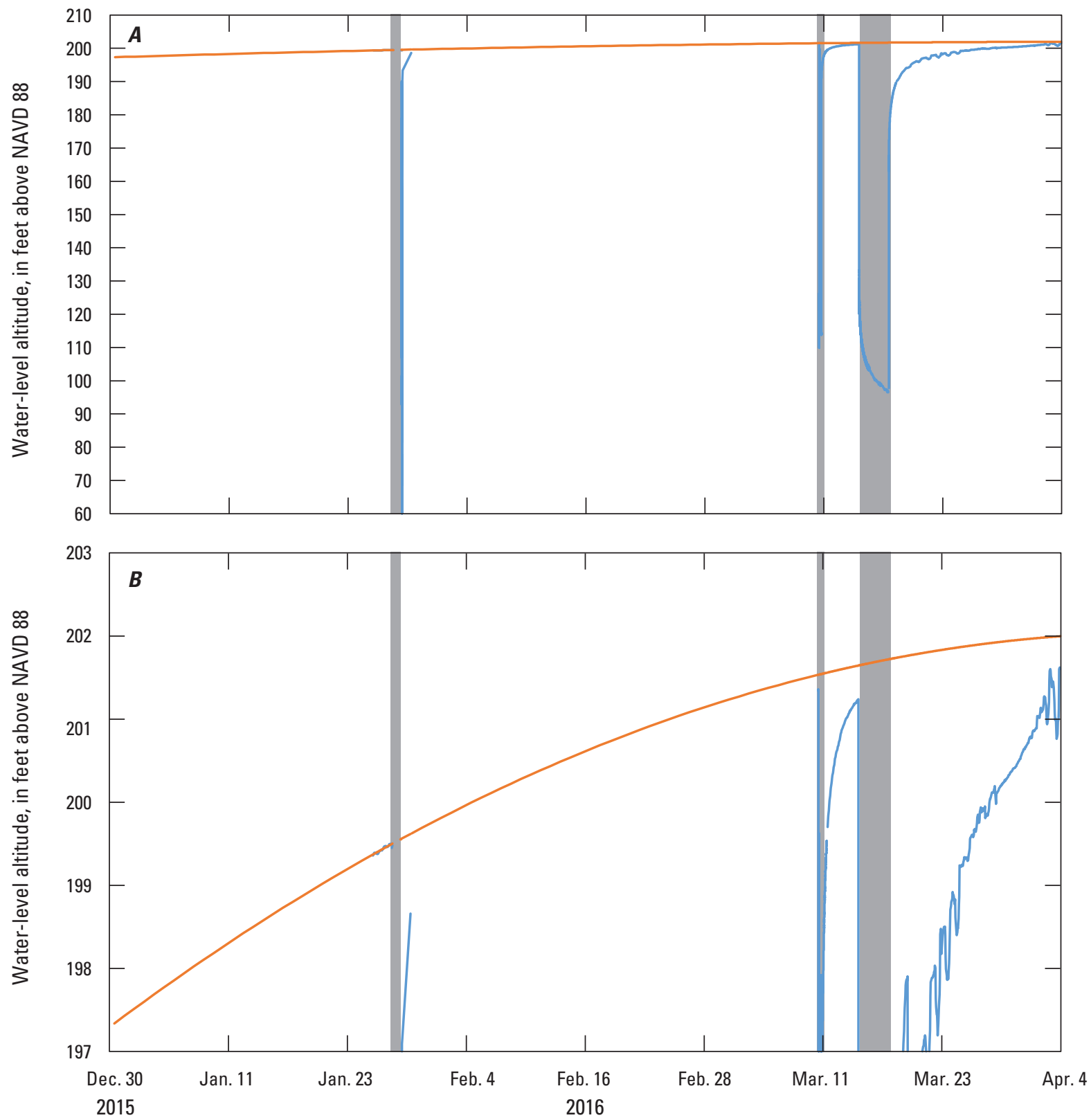

EXPLANATION

Pumping event

Water-level altitude

Background line

Figure 22. Water-level altitude and background line, Claiborne aquifer pumped well 08K026, Newberry site, northeast Early County, southeast of Arlington, Georgia, December 30, 2015 - April 4, 2016 ( $A$ has a broad vertical scale, $B$ has a close-up vertical scale).

to closely follow the part of the curve with a semi-log slope of drawdown of roughly $8 \mathrm{ft}$ per $\log$ (day) (fig. 29A). In well $08 \mathrm{~K} 025$, where well-bore storage is not a factor, the drawdown data during the first 100 minutes (about 0.07 day) of the pumping phase of the test closely follow the Theis-type curve (fig. 30A). By about 3 hours (about 0.13 day) into the test, drawdown in each of the two wells diverges from its respective type curve, with increased drawdown per time. The semi-log slope of drawdown in pumped well 08K026 increases to roughly $15 \mathrm{ft}$ per $\log$ (day) by the end of the test (fig. 29B). The semi-log slope of drawdown in monitoring well 08K025 exhibits a distinct trend, increasing with $\log$ (time). By the end of the test, the semi-log slope of the drawdown for monitoring well $08 \mathrm{~K} 025$ is slightly more than $16 \mathrm{ft}$ per $\log$ (day) (fig. $30 \mathrm{~B}$ ). The continued increase in semi-log slope with $\log ($ time) indicates that there is a nearby boundary of restricted flow or no flow (Kruseman and de Ridder, 1990). 

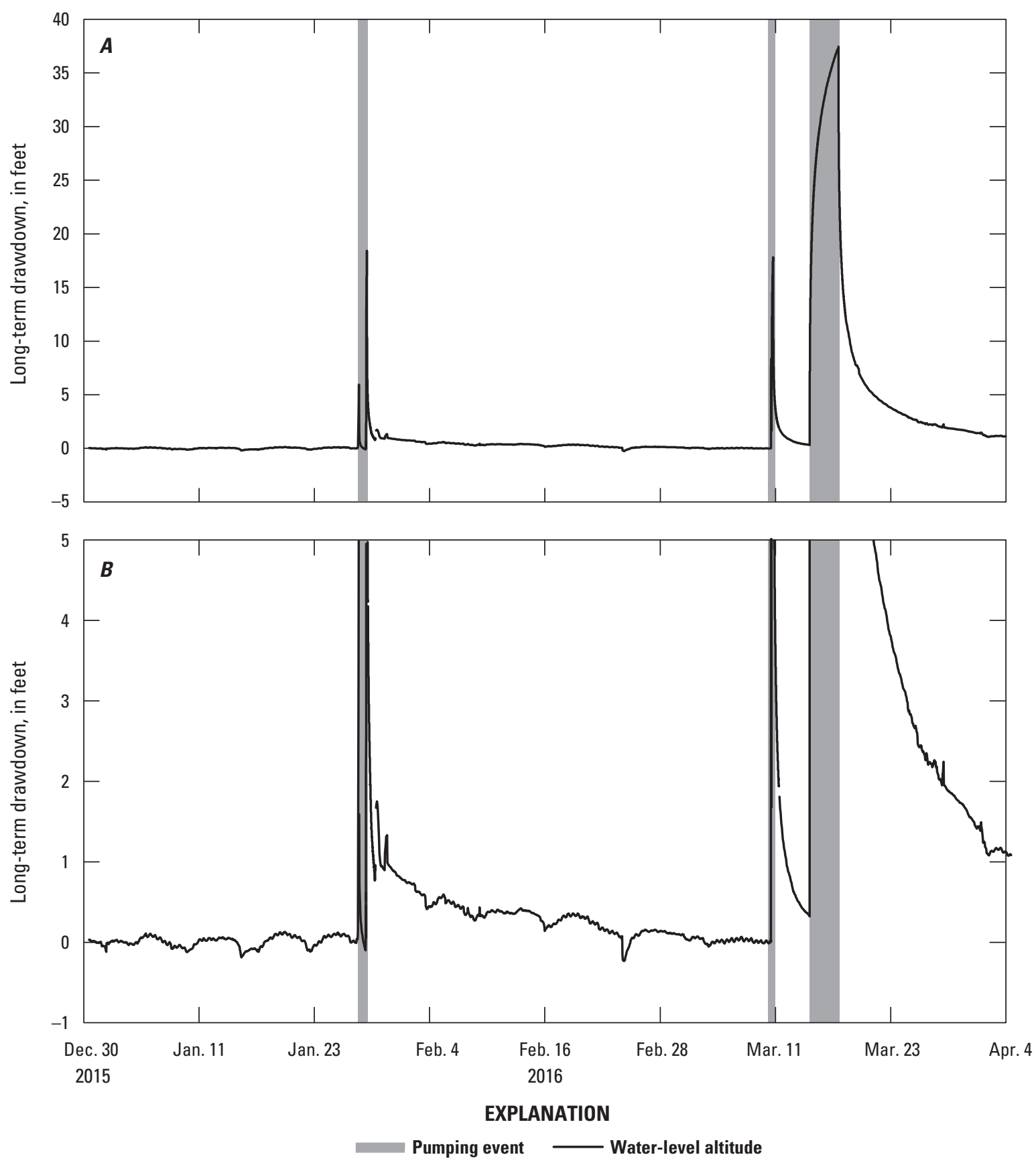

Figure 23. Long-term drawdown response in Claiborne monitoring well 08K025 to multiple pumping events, Newberry site, northeast Early County, southeast of Arlington, Georgia, December 30, 2015 - April 4, 2016 ( $A$ has a broad vertical scale, $B$ has a close-up vertical scale).

\section{Aquifer Hydraulic Properties}

The transmissivity and storage coefficient of the Claiborne aquifer were estimated by simulating the drawdown response of both Claiborne wells $08 \mathrm{~K} 026$ and $08 \mathrm{~K} 025$ to the 72-hour aquifer test using the SUMTheis macro. The drawdown was estimated based only on 72-hours of pumping during the test, from March 14-17, 2016. A separate value for the storage coefficient was applied to each well and a single transmissivity was applied to both wells. Observed drawdown values thought to be affected by wellbore storage in pumped well $08 \mathrm{~K} 026$ during the first 2 minutes of pumping were not simulated for either well. The $R M S^{\prime}$ between the simulated and observed drawdown for both wells with consideration of maximum drawdown ( $\operatorname{Max} D D_{1}$ and $M a x D D_{2}$ in equation 7) was used to objectively determine a best fit of simulated drawdown to observed drawdown simultaneously for both wells.

A broad range of $K_{x}$ and $S_{s}$ values and therefore transmissivity and storage coefficient values were input into the spreadsheet. The minimum $R M S^{\prime}$ value or best fit was with 

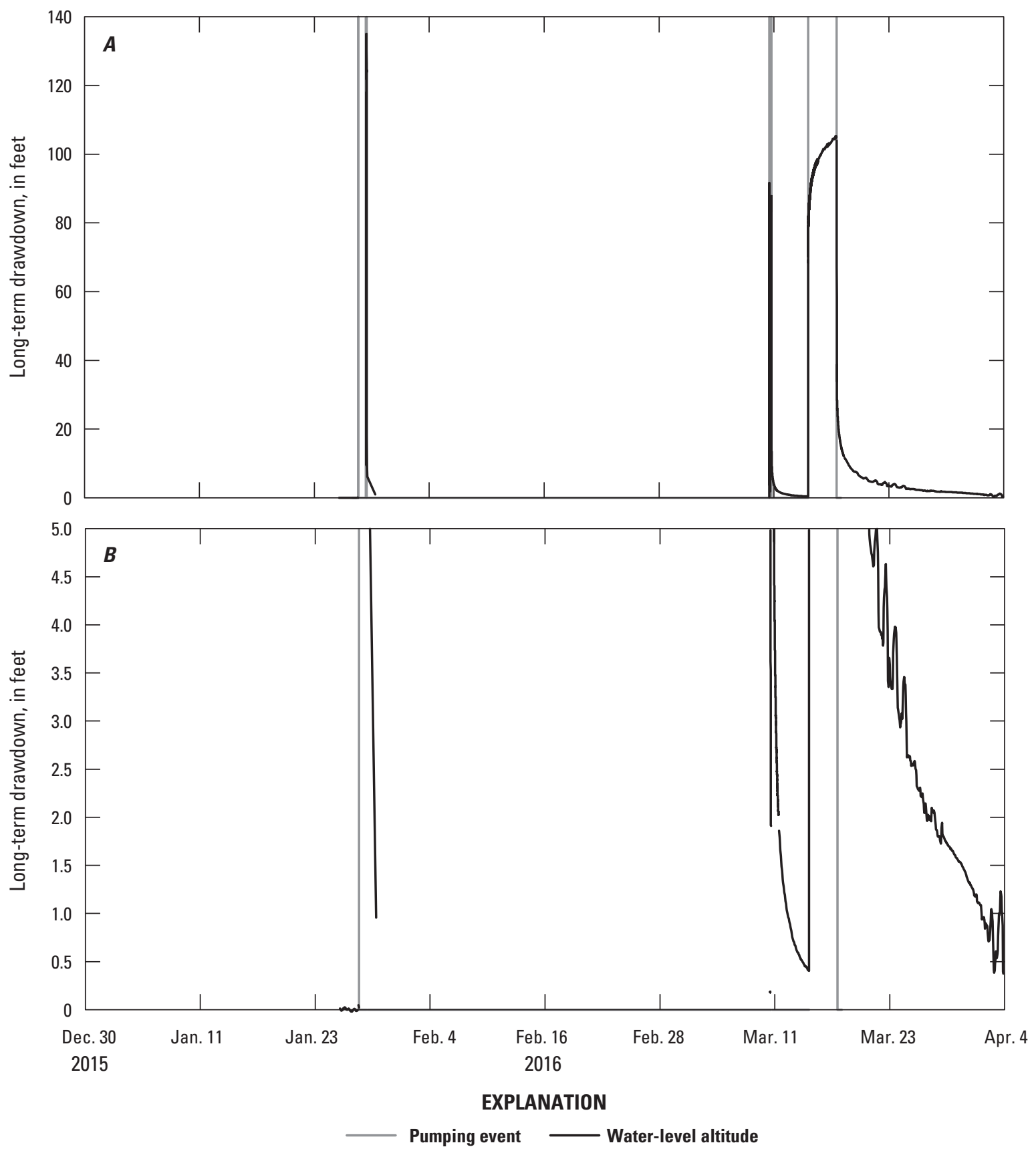

Figure 24. Long-term drawdown response in Claiborne pumped well $08 \mathrm{~K} 026$ to multiple pumping events, Newberry site, northeast Early County, southeast of Arlington, Georgia, December 30, 2015 - April 4, 2016 ( $A$ has a broad vertical scale, $B$ has a close-up vertical scale).

a transmissivity for the Claiborne aquifer of $721(700) \mathrm{ft}^{2} / \mathrm{d}$, a storage coefficient of 0.0017 for pumped well $08 \mathrm{~K} 026$, and a storage coefficient of $0.00036(0.0004)$ for monitoring well 08K025 (fig. $31 A, B$ ). Although the storage coefficient for pumped well $08 \mathrm{~K} 026$ was useful for calibration purposes, the value does not reflect the storage coefficient of the aquifer (Halford and Kuniansky, 2002). Curve matching of the earlyand intermediate-time drawdown (first 150 minutes or 0.1 day) provides a transmissivity of $700 \mathrm{ft}^{2} / \mathrm{d}$ and storage coefficient of roughly 0.0004 (table 6).
The same transmissivity and storage coefficient values used to match the pumping and recovery during the 72-hour aquifer test ( $721 \mathrm{ft}^{2} / \mathrm{d}$ and 0.00036 , respectively) were used to simulate the long-term drawdown in response to all pumping events, the two pump rate tests on March 10, 2016, and the 72-hour aquifer test on March 14-17, 2016. The simulation closely matched observed drawdown in response to all pumping events (figs. 32 and 33). 


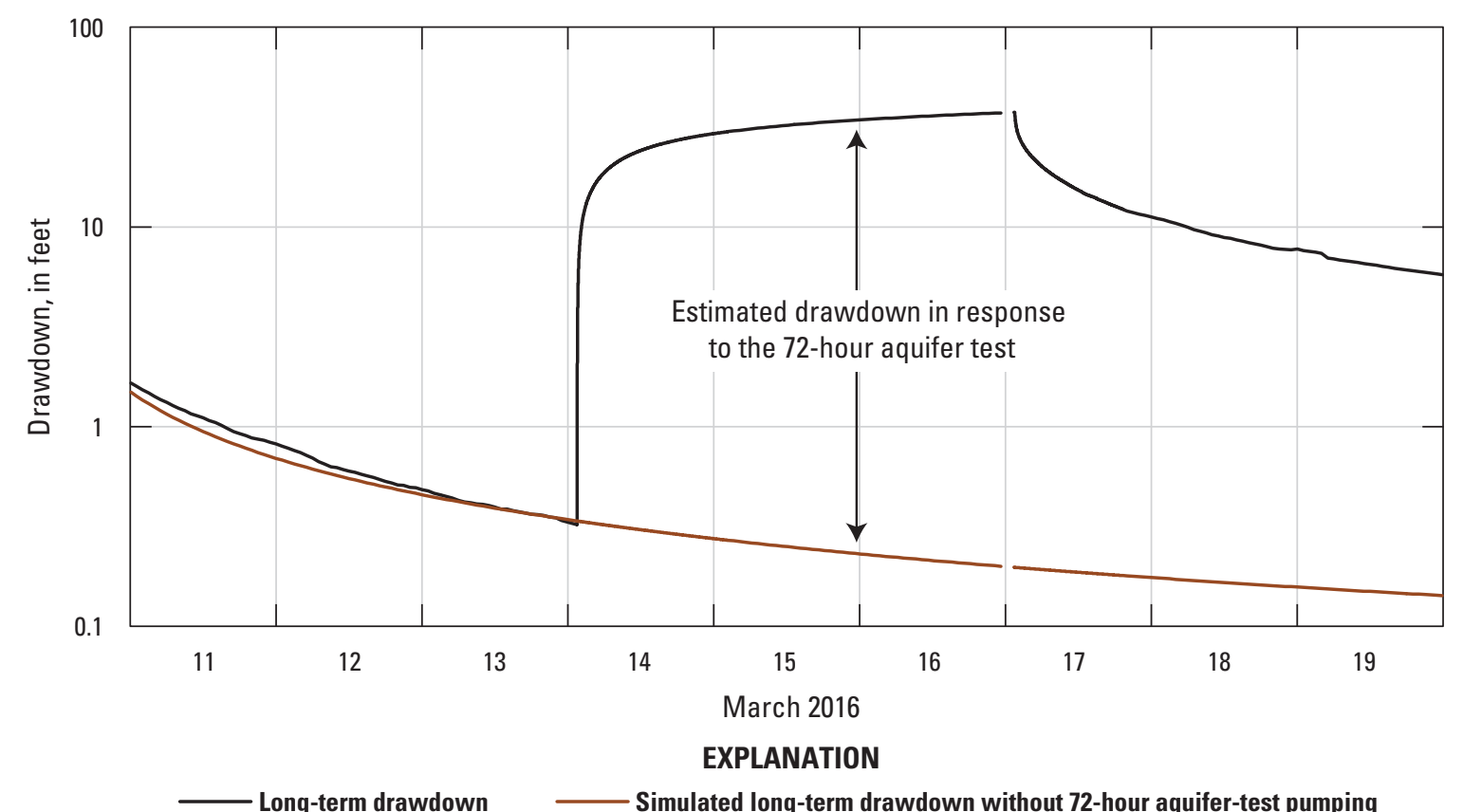

Figure 25. Example of estimating drawdown response to 72-hour aquifer test using simulated, long-term drawdown trend, Claiborne aquifer monitoring well 08K025, Newberry site, northeast Early County, southeast of Arlington, Georgia, March 9-28, 2016.

\section{Sensitivity Analysis}

To assess the viability of the SUMTheis simulation, a sensitivity analysis of water-level response (drawdown) to changes in input parameters was completed. The input parameters included the transmissivity of the Claiborne aquifer and the specific storage used at each of the Claiborne wells. Values of each parameter were adjusted while the other two parameters were kept constant at the calibrated value. Adjusted values ranged from 0.20 to 5 times that of the calibrated value. The wellness-of-fit for each value adjustment was measured using the $R M S^{\prime}$ (equation 7), the lower the $R M S^{\prime}$, the better the fit between simulated and observed drawdown. The $R M S^{\prime}$ values for the three parameters were plotted as a function of the ratio adjusted to calibrated parameter values (fig. 34)

Drawdown was most sensitive to Claiborne aquifer transmissivity and least sensitive to the storage coefficient used for pumped well $08 \mathrm{~K} 026$. The $R M S^{\prime}$ has a pronounced minimum for the calibrated value of transmissivity (fig. 34B). Transmissivity values between 705 and $734 \mathrm{ft}^{2} / \mathrm{d}$ yield resulting $R M S^{\prime}$ values that are within 5 percent of minimum $R M S^{\prime}$ (less than 1.05 times the $R M S^{\prime}$ for the calibrated SUMTheis model). Being within 5 percent of minimum $R M S^{\prime}$ as a criteria for a confidence interval, the estimate of transmissivity is approximately \pm 2 percent. Using the 5-percent criteria, the storage coefficient for monitoring well $08 \mathrm{~K} 025$ has a range of 0.00031 to 0.00042 , or roughly \pm 15 percent. The storage coefficient for pumped well $08 \mathrm{~K} 026$ is relatively insensitive, ranging from about 0.0012 to 0.0024 , or roughly \pm 40 percent.

\section{Aquifer Connectivity}

The aquifer tests at the Stripling and Newberry sites involved pumping a well in the Claiborne aquifer while monitoring water-level response in the adjacent Claiborne and Upper Floridan aquifer monitoring wells in order to detect any connection between the two aquifers. As discussed in the aquifer test sections above, no measureable drawdown caused by Claiborne aquifer pumping was detected in the Upper Floridan aquifer at either site. The time-drawdown data for the Claiborne aquifer during the Stripling aquifer test suggest, however, that the aquifer did receive some water from another aquifer. Because the models predict that there was aquifer leakage in the Claiborne yet no response in the Upper Floridan, there appears to be a connection between the Claiborne and Clayton aquifers at the Stripling site. The models predict a vertical hydraulic conductivity through the overlying Lisbon confining unit of $0.007 \mathrm{ft} / \mathrm{d}$ and through the underlying Wilcox confining unit of $0.022 \mathrm{ft} / \mathrm{d}$. These data suggest that a small amount of leakage from the underlying Clayton aquifer is likely at the Stripling site, whereas there does not seem to be a connection between the Claiborne aquifer and the overlying Upper Floridan aquifer at either the Stripling or Newberry sites. 
A
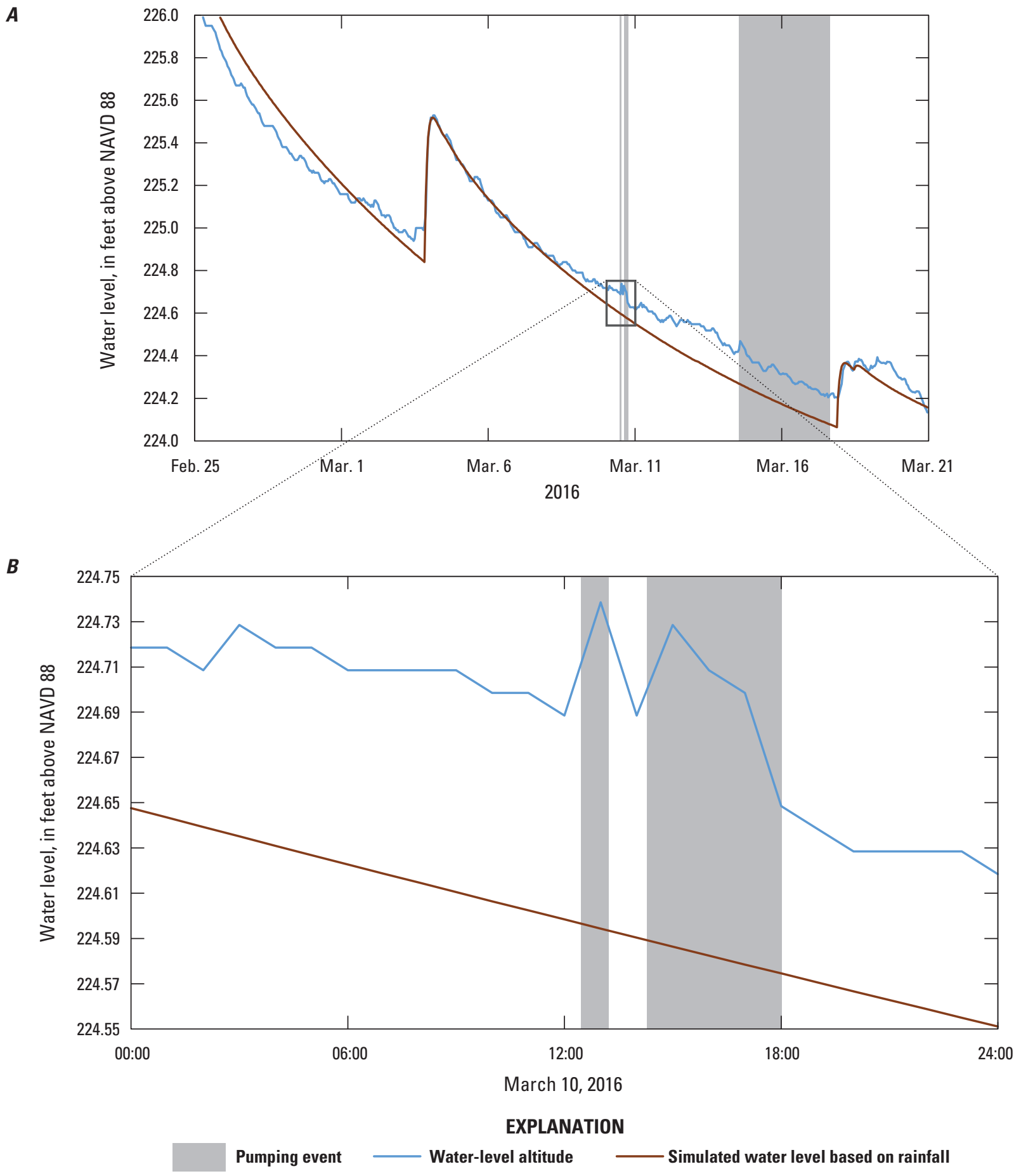

B

Figure 26. Observed and simulated water-level altitude at Upper Floridan aquifer state-wide network well 08K001, Newberry site, northeast Early County, southeast of Arlington, Georgia, A, February 25 - March 21, 2016, B, close-up of water-level spikes during pump rate tests, March 10, 2016. 

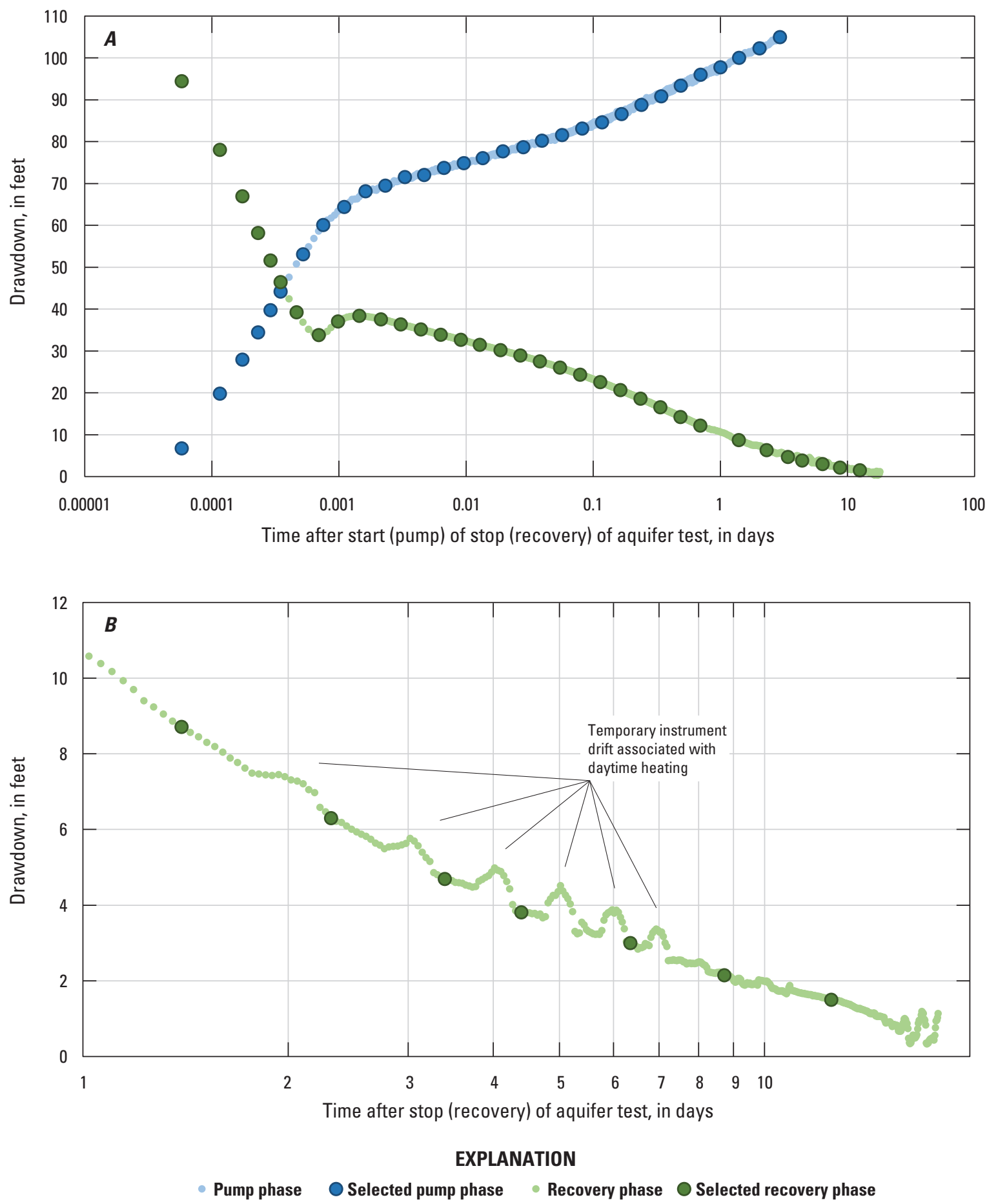

Figure 27. Drawdown observations (total and selected) in Claiborne aquifer pumped well $08 \mathrm{~K} 026$ in response to the 72-hour aquifer test, Newberry site, northeast Early County, southeast of Arlington, Georgia; A, March 14-30, 2016, and $B$, from 1 to 10 days into the recovery phase of the test. 


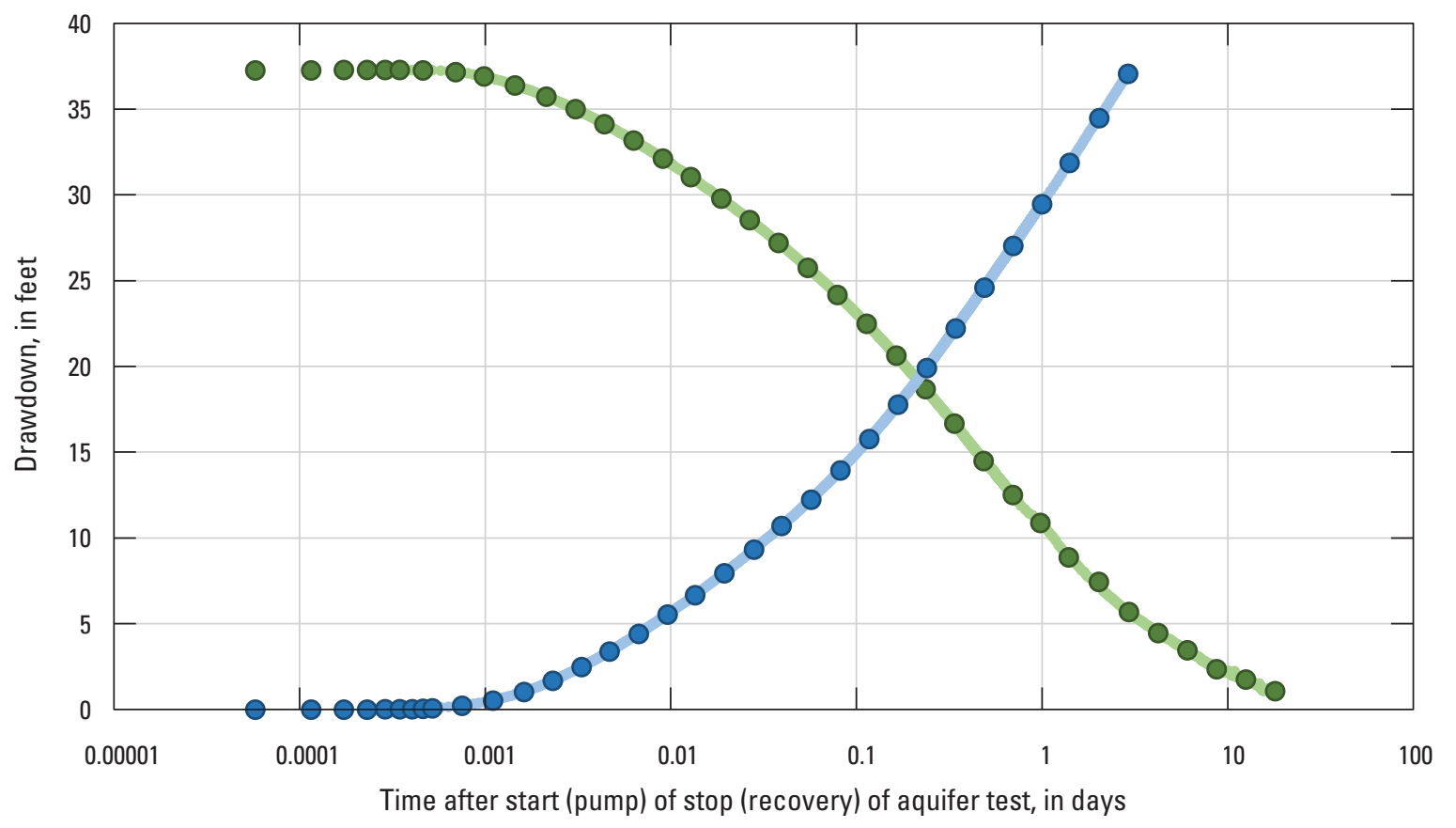

\section{EXPLANATION}

- Pump phase $\bigcirc$ Selected pump phase $\quad$ Recovery phase $\bigcirc$ Selected recovery phase

Figure 28. Drawdown observations (total and selected) in Claiborne aquifer monitoring well $08 \mathrm{~K} 025$ in response to the 72-hour aquifer test, Newberry site, northeast Early County, southeast of Arlington, Georgia, March 14-30, 2016.

\section{Areal Distribution of Claiborne Aquifer Hydrologic Properties}

Claiborne aquifer hydrologic properties vary across the study area. Data collected during this study show that the thickness and lithology of the aquifer changes areally, and data from the two 72-hour aquifer tests indicate the hydrologic properties calculated from the data also vary areally across the study area

The transmissivity of the Claiborne aquifer calculated from aquifer tests is $1,500 \mathrm{ft}^{2} / \mathrm{d}$ at the Stripling site and 700 $\mathrm{ft}^{2} / \mathrm{d}$ at the Newberry site. These values are lower than values obtained from aquifer tests in northern Dougherty County to the northeast and in southern Early and northern Seminole Counties to the southwest. These values are also lower than the calibrated transmissivity reported in a regional groundwater-flow model by Faye and Mayer (1997). The differences between estimates of transmissivity determined by Faye and Mayer (1997) and those calculated in this report result from the availability of additional data collected for study. These additional data include transmissivity values calculated from the two aquifer tests conducted for this study and five wells where estimates of specific capacity were made. The new data indicate that there is more variability in the hydrologic properties of the Claiborne aquifer than previously determined by Faye and Mayer, allowing for more detailed mapping of the distribution of transmissivity than before. Using the data available at the time, Faye and Mayer calibrated their model with transmissivities of the Claiborne aquifer that ranged from 1,000 to $5,000 \mathrm{ft}^{2} / \mathrm{d}$ in the area of this study. The authors also used leakance values of about $2 \times 10^{-6} / \mathrm{d}$ for the confining unit above the Claiborne aquifer and about $4 \times 10^{-7} / \mathrm{d}$ for the confining unit below the Claiborne aquifer. These values are much lower than those used for the axisymmetric model at the Stripling site for the purposes of the current study. The values of leakance that Faye and Mayer used in their model were derived from more limited field data than are available for the current axisymmetric model and consequently resulted in the observed differences between the two models. It is likely that Faye and Mayer would have produced results for transmissivity similar to those calculated for this study if the current data set had been available at the time. In this context, the current modeling results are not considered to contradict those of Faye and Mayer, but rather enhance the overall understanding of the hydrology of the area.

Additional transmissivity values were estimated from specific capacity values provided to the GaEPD as part of a well permit application. Specific capacity, which is the constant well pumping rate divided by the total drawdown measured in the pumping well, was used to estimate transmissivity as described in Driscoll (1986, appendix 16D). Transmissivity values estimated from specific capacity are typically less reliable than those calculated from aquifer test data because of the assumptions made for the simplified Cooper and Jacob (1946) nonequilibrium equation. As with an 

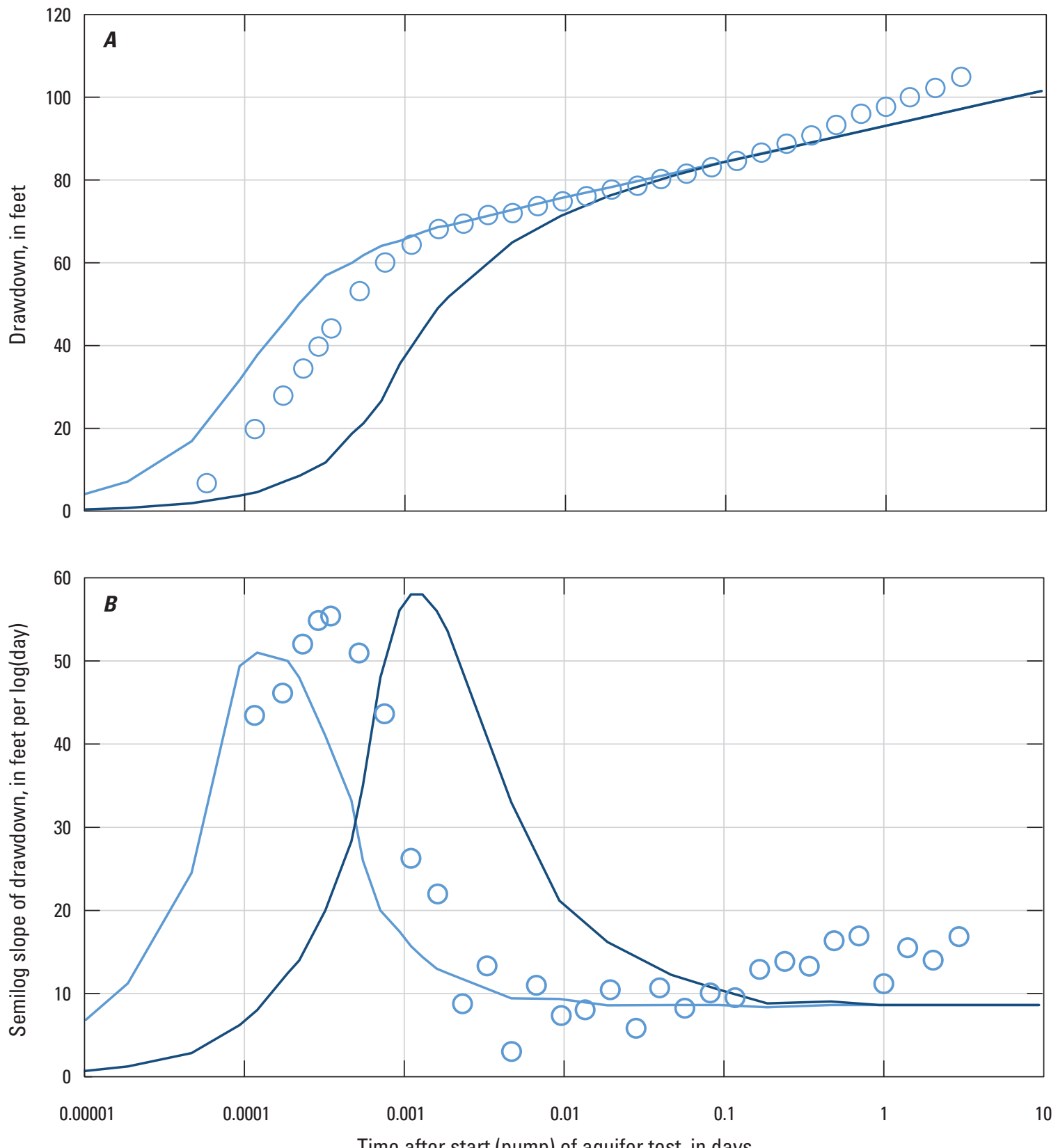

Time after start (pump) of aquifer test, in days

\section{EXPLANATION}

O Selected pump observed drawdown

- Papadopulos-Cooper curve, alpha=1E-6, rho=1

Papadopulos-Cooper curve, alpha=1E-7, rho=1

Figure 29. Semi-log plots of, $A$, time versus drawdown and, $B$, slope of drawdown in Claiborne aquifer pumped well $08 \mathrm{~K} 026$ and select Papadopulos-Cooper curves. 


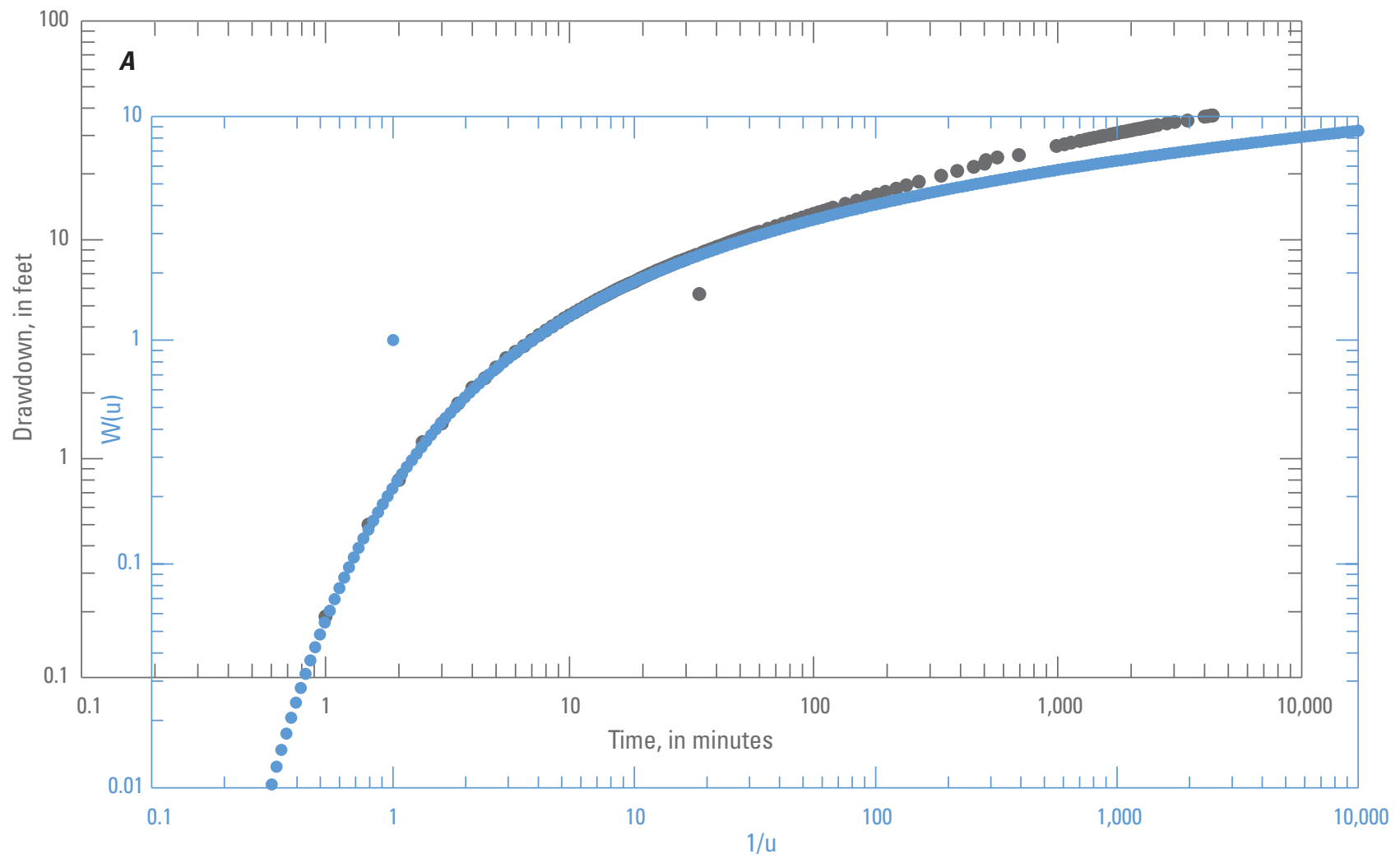

EXPLANATION

- Newberry time versus drawdown Theis nonequilibrium reverse-type curve

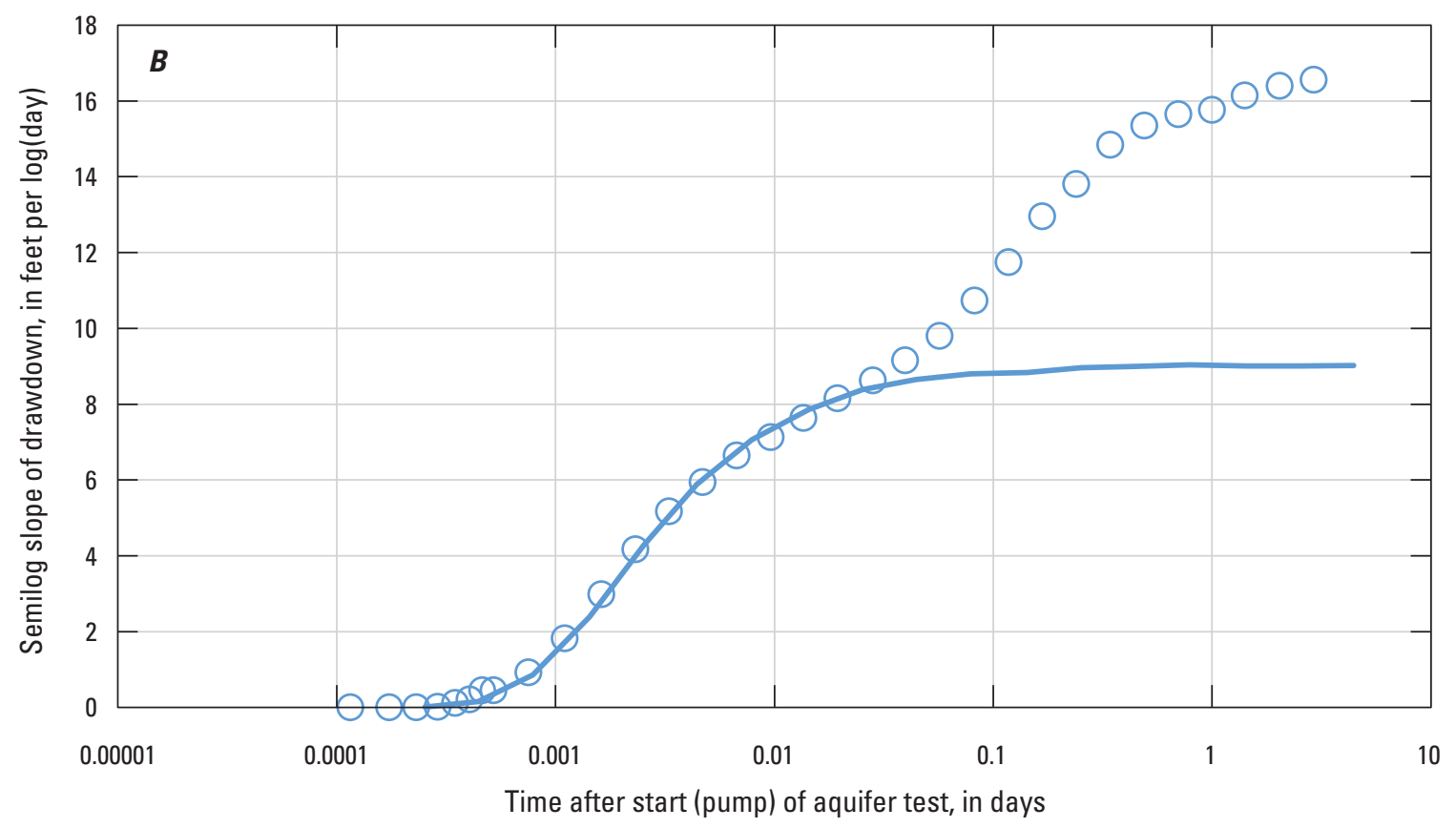

EXPLANATION

Selected pump observed drawdown Theis curve

Figure 30. A, Log-log plot of time versus drawdown data and the Theis curve; and $B$, semi-log slope of drawdown in Claiborne aquifer monitoring well $08 \mathrm{~K} 025$. 

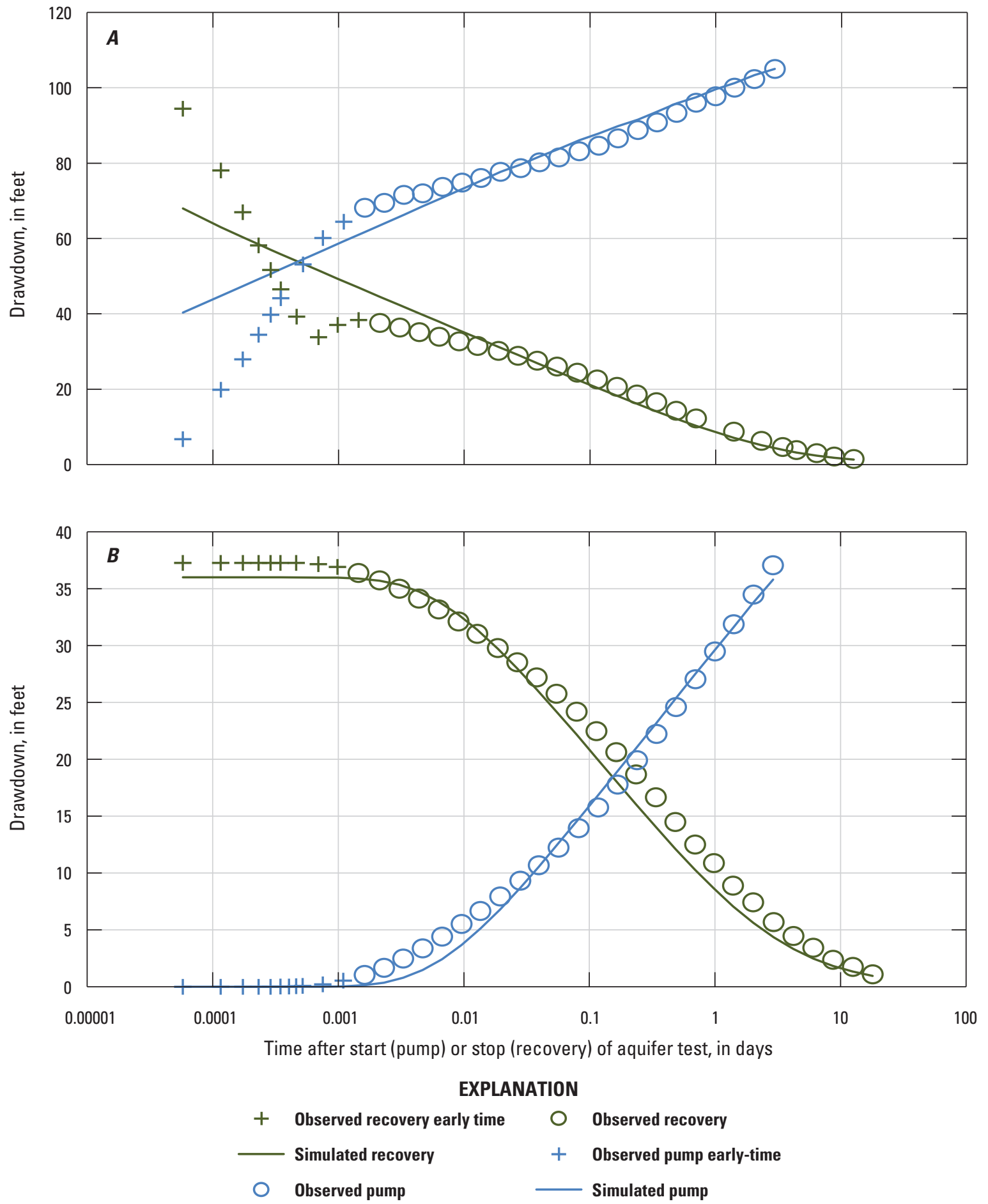

Figure 31. Comparison of simulated and observed drawdown from a 72-hour aquifer test at Claiborne aquifer wells, Newberry site, northeast Early County, southeast of Arlington, Georgia, March 14-24, 2016, for, A, pumped well $08 \mathrm{~K} 026$ and, $B$, monitoring well $08 \mathrm{~K} 025$. 
Table 6. Summary of 72-hour aquifer-test results, Claiborne aquifer, Newberry site, northeast Early County, southeast of Arlington, Georgia, March 14-17, 2016.

[Well: PW, pumped well, the well that was pumped for the 72-hour aquifer test; MW, monitor well. $\mathrm{ft}$, foot; $\mathrm{ft}^{2} / \mathrm{d}$, foot squared per day]

\begin{tabular}{|c|c|c|c|c|}
\hline \multirow[b]{2}{*}{$\begin{array}{c}\text { USGS } \\
\text { well } \\
\text { identifier }\end{array}$} & \multirow[b]{2}{*}{ Hydrogeologic unit } & \multirow[b]{2}{*}{$\begin{array}{l}\text { Distance from the center } \\
\text { of pumping } \\
\text { (ft) }\end{array}$} & \multicolumn{2}{|c|}{ Maximum drawdown (ft) } \\
\hline & & & Observed & $\begin{array}{l}\text { Simulated, } \\
\text { calibrated } \\
\text { SUMTheis }\end{array}$ \\
\hline 08K026 (PW) & Claiborne aquifer & 0.33333 & 105.0 & 105.0 \\
\hline 08K001 (MW) & Upper Floridan aquifer & 84 & None detected & None simulated \\
\hline 08K025 (MW) & Claiborne aquifer & 201 & 37.1 & 35.8 \\
\hline
\end{tabular}

Calibrated transmissivity: $700 \mathrm{ft}^{2} / \mathrm{d}$

Calibrated storage coefficient: 0.0004

aquifer test, estimating transmissivity from specific capacity data requires that the well is pumped at a constant rate and that drawdown stabilizes.

A simple linear regression analysis of the transmissivity values obtained from aquifer test data and transmissivity estimated from specific capacity was performed to determine how well specific capacity predicts transmissivity of the Claiborne aquifer in the study area (fig. 35, table 7). Only five wells presented in this report have both transmissivity values from aquifer tests and specific capacity data and thus could be used to compare the two methods of estimating transmissivity. The resulting relation is

$$
y=1.1648 x+80.116\left(R^{2}=0.96\right)
$$

where

$\mathrm{y} \quad$ is the transmissivity, in feet squared per day; and

$\mathrm{x} \quad$ is the specific capacity, in gallons per minute, per foot of drawdown.

An $\mathrm{R}^{2}$ of 0.96 suggests that 96 percent of the variation in transmissivity can be explained by the variation in specific capacity.

The distribution of transmissivity in the study area was compiled from aquifer test data, specific capacity data, well records, and data from a USGS database and GaEPD files. The most reliable values of transmissivity, calculated using aquifer test data, are shown for wells shaded in blue in figure 36 . The transmissivity of the Claiborne aquifer in the study area ranges from about $700 \mathrm{ft}^{2} / \mathrm{d}$ in eastern Early County where the aquifer is thin ( $70 \mathrm{ft}$ thick) to $4,000 \mathrm{ft}^{2} / \mathrm{d}$ and greater where the aquifer is more than $300 \mathrm{ft}$ thick. These values compare well with those reported in McFadden and Perriello (1983).

The storage coefficient was estimated for the Claiborne aquifer using the analytical methods and models to estimate data from the two aquifer tests. The best estimate of the storage coefficient is 0.0006 at the Stripling site and 0.0004 at the Newberry site.

\section{Summary and Conclusions}

Since 2012, numerous wells have been installed in the Claiborne aquifer in subarea 4 of southwestern Georgia. Information from some of these new Claiborne wells was used to refine the thickness and extent of the Claiborne aquifer. Borehole geophysical logs were used to refine the top and base of the Claiborne and overlying Upper Floridan aquifers and to identify water-bearing zones. Two aquifer tests were performed to determine the hydrologic properties of the Claiborne aquifer and its interconnection with the Upper Floridan aquifer.

Borehole geophysical logs and lithologic descriptions based on drill cuttings from newly constructed wells were used to help define the extent of the Claiborne aquifer in those locations. The top of the aquifer extends from an altitude of about 150 feet (ft) above the North American Vertical Datum of 1988 (NAVD 88) in eastern Sumter County to about $402 \mathrm{ft}$ below NAVD 88 in Decatur County. The base of the aquifer extends from an altitude of about $60 \mathrm{ft}$ above NAVD 88 in eastern Sumter County to about $690 \mathrm{ft}$ below NAVD 88 in Decatur County.

Two 72-hour aquifer tests were conducted and the data obtained were analyzed to determine the transmissivity and storage coefficient of the Claiborne aquifer, and the vertical hydraulic conductivity of the Wilcox confining unit. Both tests had a production well open to the Claiborne aquifer and a monitoring well open to each of the Claiborne and Upper Floridan aquifers.

The first test was conducted at the Stripling site in Mitchell County near Camilla, Georgia. Analyses of the data indicate that the Claiborne aquifer has a transmissivity of 1,500 feet squared per day $\left(\mathrm{ft}^{2} / \mathrm{d}\right)$ and a storage coefficient of 0.0006 . The data also indicate that a small amount of leakage occurred during the test. Because no drawdown was measured in the overlying Upper Floridan aquifer during the pumping phase of the test, the source of leakage is assumed to be the underlying Clayton aquifer. Model simulation predicts a drawdown of about $2.5 \mathrm{ft}$ in the Clayton aquifer in response 

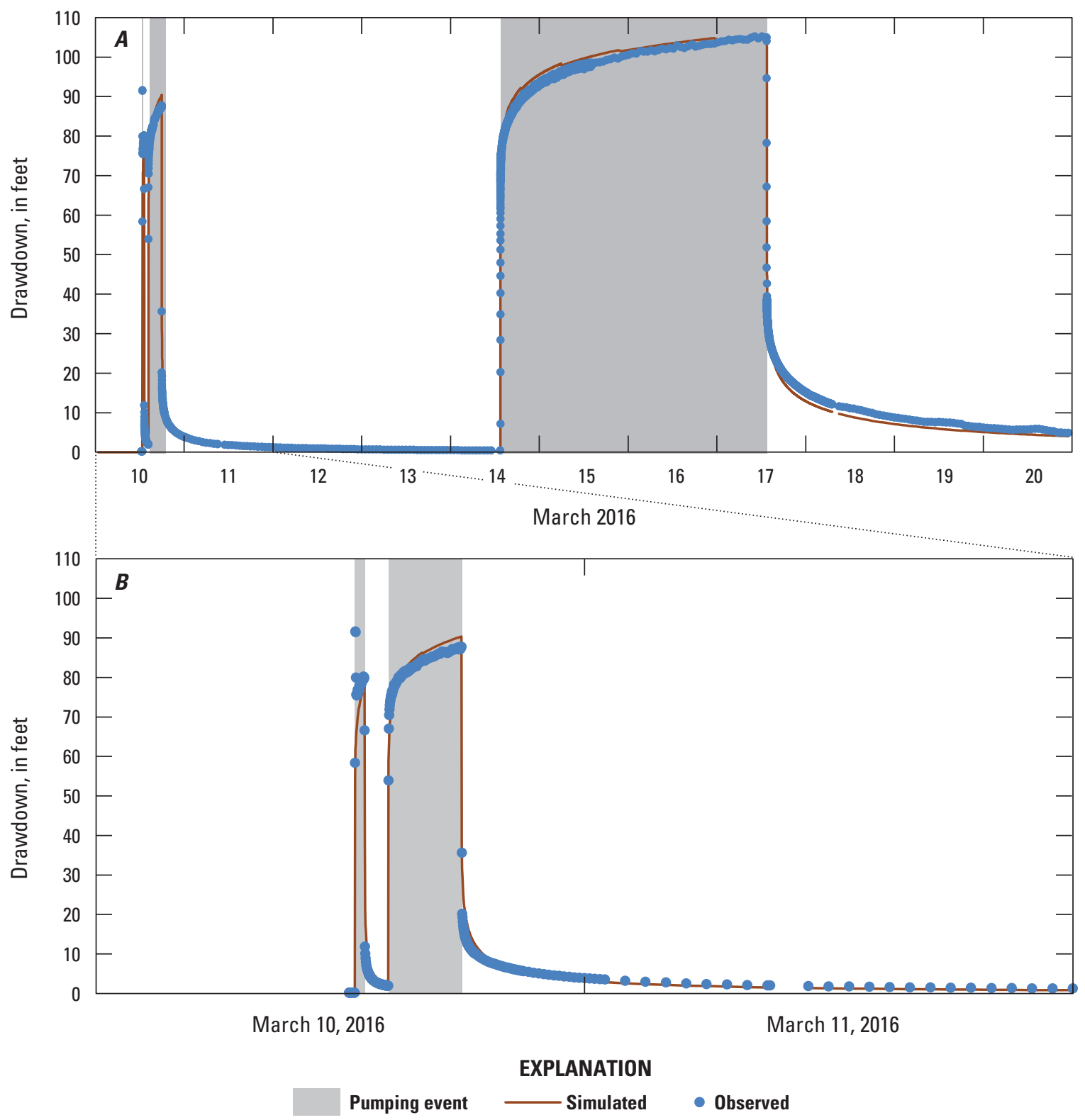

Figure 32. Simulated and observed drawdown using Theis drawdown and superposition during three pumping events at Claiborne aquifer pumped well 08K026 ( $A$, March 10-21, 2016; and $B$, March 10-12, 2016), Newberry site, northeast Early County, southeast Arlington, Georgia.

to pumping in the Claiborne aquifer; the vertical hydraulic conductivity of the confining unit separating the Claiborne and Clayton aquifers was simulated to be about 0.02 foot per day.

The second aquifer test was conducted at the Newberry site in eastern Early County outside of Arlington, Georgia. Analyses of the data from this test indicate a transmissivity of about $700 \mathrm{ft}^{2} / \mathrm{d}$ and a storage coefficient of about 0.0004 for the Claiborne aquifer. No leakage was detected during pumping, indicating that the Claiborne aquifer is not hydraulically connected to the overlying Upper Floridan aquifer or the underlying Clayton aquifer at this site.

The transmissivity of the Claiborne aquifer ranges from about 700 to over $4,000 \mathrm{ft}^{2} / \mathrm{d}$ across the study area. Specific capacity data were used to estimate transmissivity where aquifer test data were not available. Although regression analyses indicated that the estimates are reasonable $\left(\mathrm{R}^{2}=0.96\right)$, only five sites were used, and the estimates rely on more assumptions than transmissivity calculated from aquifer tests.

Additional data are needed to monitor the effects that the increased withdrawals from the Claiborne aquifer will have on future water resources. Long-term monitoring and potentiometric surfaces of the Upper Floridan, Claiborne, and Clayton aquifers during different hydrologic conditions will better show responses to changes in withdrawals from the different aquifers and indicate linkages among or between them. Analysis of water-level data collected from monitoring 

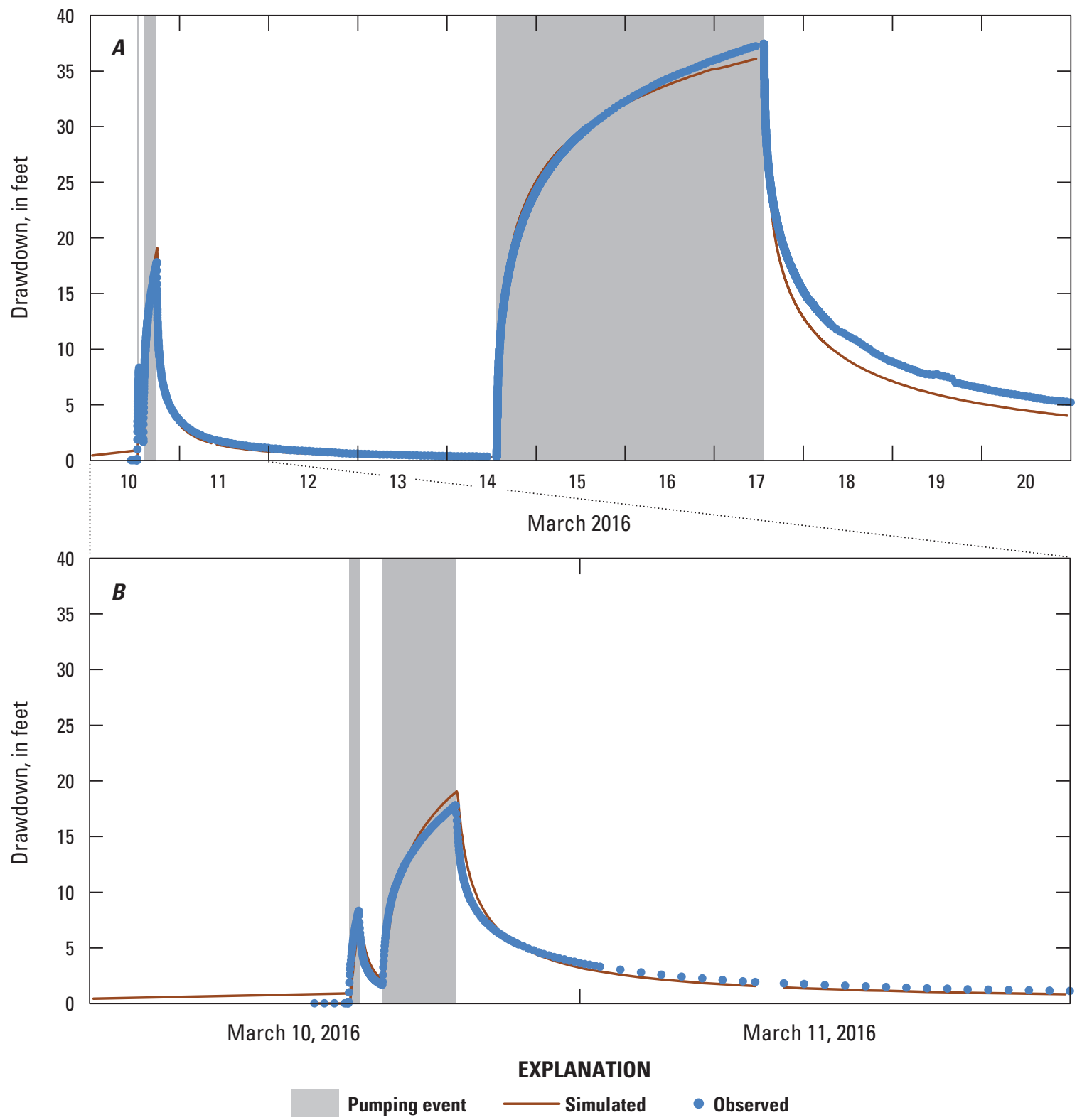

Figure 33. Comparison of simulated and observed drawdown using Theis drawdown and superposition on three pumping events at Claiborne aquifer monitoring well 08K025, (A, March 10-21, 2016; and B, March 10-12, 2016), Newberry site, northeast Early County, southeast Arlington, Georgia. 


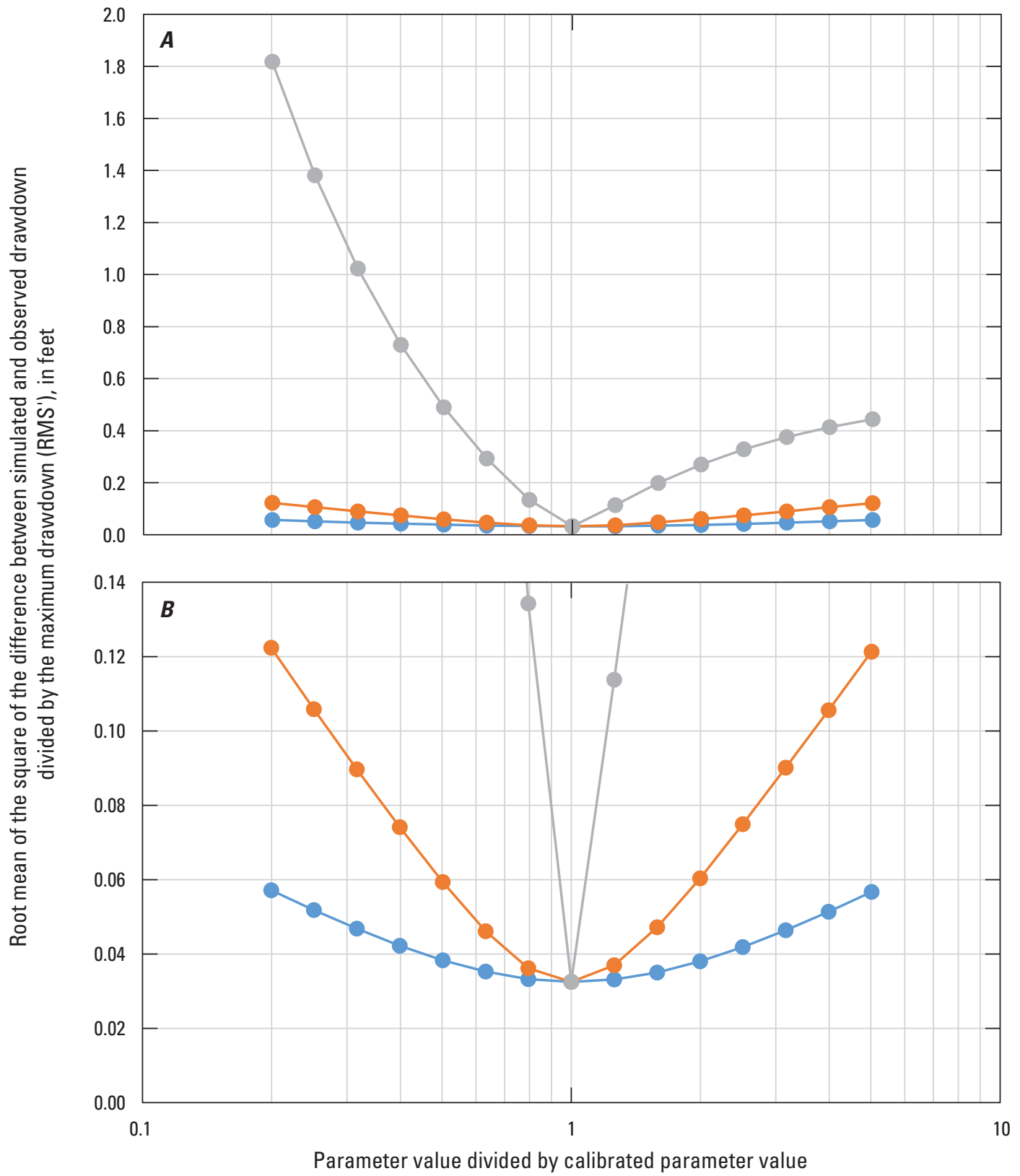

EXPLANATION

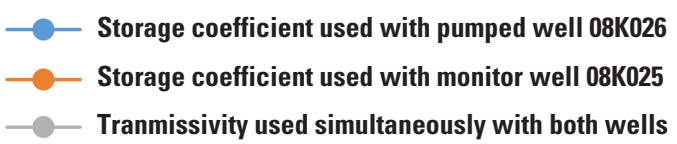

Figure 34. Root mean of the square of the sum of the difference between simulated and observed drawdown in response to the 72-hour aquifer test divided by maximum drawdown, for different values of transmissivity and storage coefficient for both Claiborne wells $08 \mathrm{~K} 026$ and 08K025, Newberry site, northeast Early County, southeast of Arlington, Georgia, March 14-20, 2016. Graph $A$ shows values of $R M S^{\prime}$ between 0.0 and 2.0, and graph $B$ shows values of $R M S^{\prime}$ between 0.0 and 0.14 . 
Figure 35. Linear regression of transmissivity values estimated from specific capacity data and transmissivity calculated from aquifer test data.

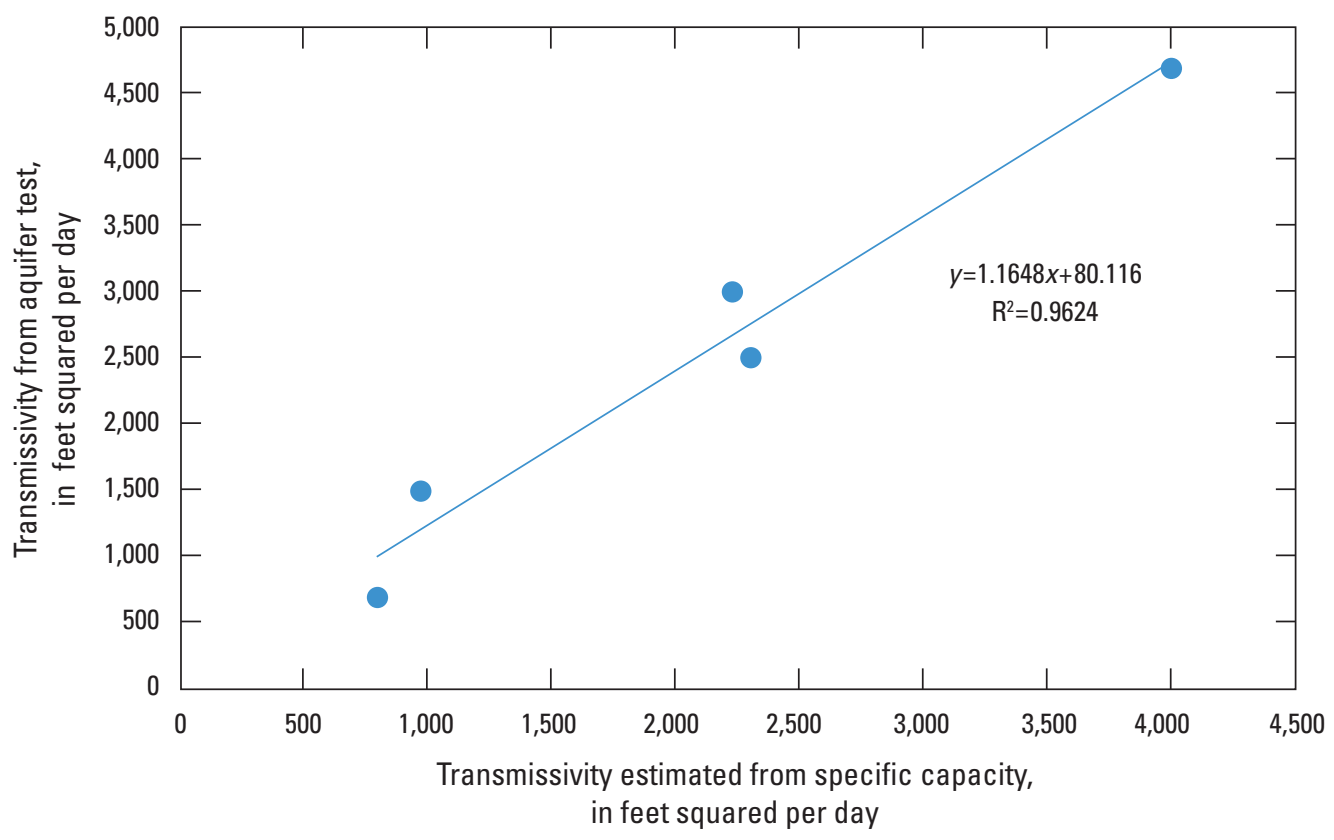

Table 7. Values of transmissivity estimated from specific capacity and transmissivity calculated from aquifer test data in the Claiborne aquifer in southwestern, Georgia.

[USGS, U.S. Geological Survey; gal/min, gallon per minute; ft, foot; gal/d, gallon per day; $\mathrm{ft}^{2} / \mathrm{d}$, foot squared per day]

\begin{tabular}{|c|c|c|c|c|c|c|c|}
\hline \multirow{2}{*}{$\begin{array}{c}\text { USGS } \\
\text { well } \\
\text { identifier }\end{array}$} & \multirow{2}{*}{$\begin{array}{l}\text { Discharge, } \\
\text { in gal/min }\end{array}$} & \multirow{2}{*}{$\begin{array}{c}\text { 24-h } \\
\text { drawdown, } \\
\text { in } \mathrm{ft}\end{array}$} & \multirow{2}{*}{$\begin{array}{c}\text { 24-h } \\
\text { specific } \\
\text { capacity, in } \\
\text { (gal//min)/ft }\end{array}$} & \multicolumn{2}{|c|}{$\begin{array}{l}\text { Transmissivity from } \\
\text { specific capacity }\end{array}$} & \multirow{2}{*}{$\begin{array}{c}\begin{array}{c}\text { Transmissivity } \\
\text { from aquifer test }\end{array} \\
\mathbf{f t}^{2} / \mathbf{d}\end{array}$} & \multirow{2}{*}{$\begin{array}{c}\text { Transmissivity } \\
\text { method }\end{array}$} \\
\hline & & & & $(\mathrm{gal} / \mathrm{d}) / \mathrm{ft}$ & $\mathrm{ft}^{2} / \mathrm{d}$ & & \\
\hline $11 \mathrm{~J} 029$ & 590 & 161.7 & 3.65 & $7,297.46$ & 976 & 1,500 & $\begin{array}{l}\text { Axisymmetric } \\
\text { model }\end{array}$ \\
\hline 08K026 & 292 & 97.8 & 2.99 & $5,971.37$ & 798 & 700 & Sum Theis \\
\hline 13L022 & 1,660 & 193 & 8.60 & $17,202.07$ & 2,300 & 2,500 & Cooper-Jacob \\
\hline 06G018 & 550 & 66 & 8.33 & $16,666.67$ & 2,228 & 3,900 & Cooper-Jacob \\
\hline
\end{tabular}




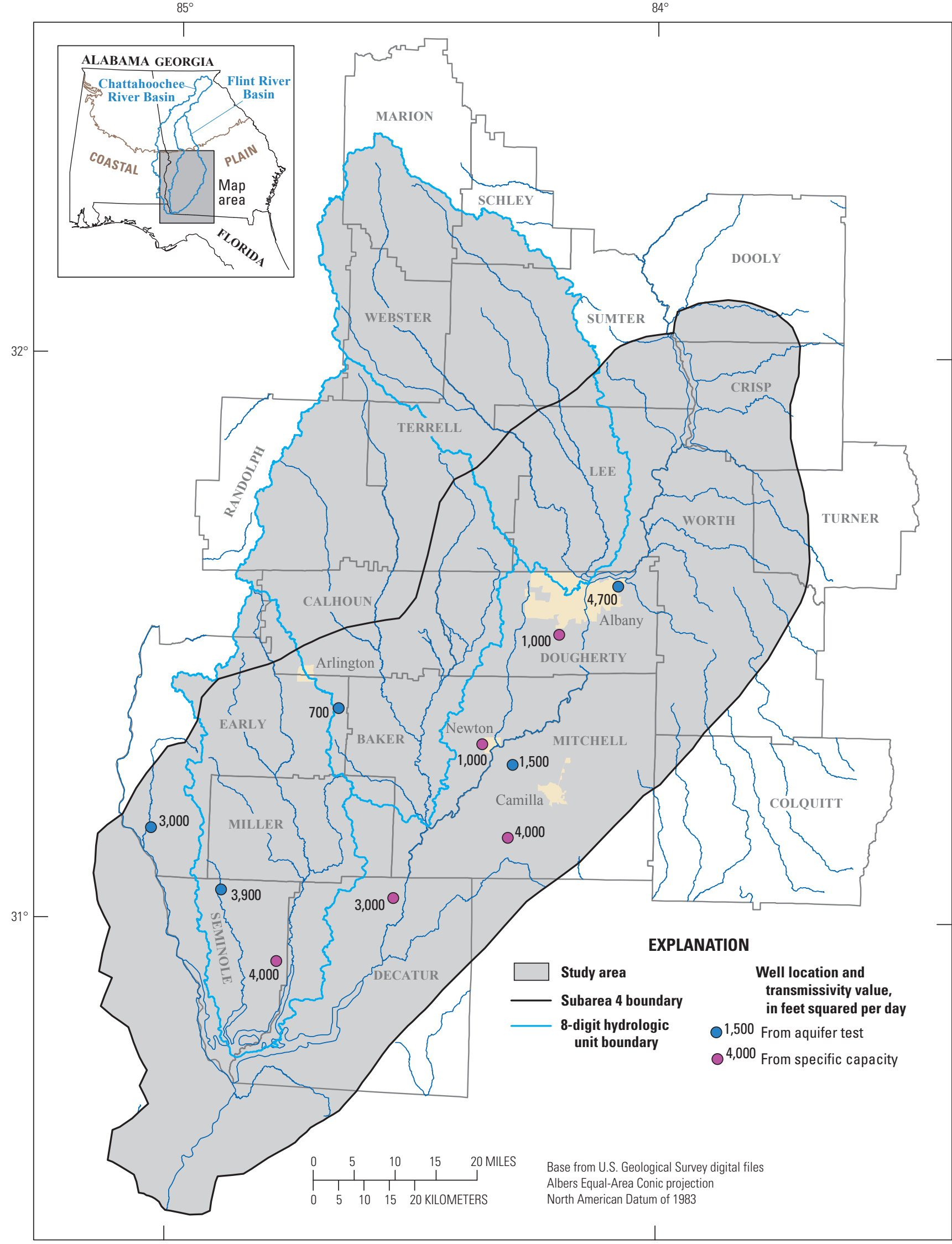

Figure 36. Distribution of transmissivity of the Claiborne aquifer in southwestern Georgia. 
wells in the Clayton aquifer during periods of pumping from the Claiborne aquifer would provide empirical data needed to validate model predictions that the two aquifers are connected.

\section{Selected References}

Back, William, 1966, Hydrochemical facies and ground-water flow patterns in northern part of Atlantic Coastal Plain: U.S. Geological Survey Professional Paper 498-A, 42 p.

Batu, Vedat, 1998, Aquifer hydraulics-A comprehensive guide to hydrogeologic data analysis: New York, John Wiley \& Sons, Inc., 727 p.

Clarke, W.Z., Jr., and Zisa, A.C., 1976, Physiographic map of Georgia: Georgia Department of Natural Resources, Georgia Geologic Survey, scale 1:2,000,000.

Clarke, J.S., Faye, R.E., and Brooks, Rebekah, 1984, Hydrogeology of the Clayton aquifer of southwest Georgia: Georgia Geologic Survey Hydrologic Atlas 13, 6 pls.

Clemo, Tom, 2002, MODFLOW-2000 for cylindrical geometry with internal flow observations and improved watertable simulation: Boise, Idaho, Boise State University Technical Report BSU CGISS 02-01, 29 p.

Cooper, H.H., and Jacob, C.E., 1946, A generalized graphical method for evaluating formation constants and summarizing well-field history: Transactions, American Geophysical Union, v. 27, no. IV, p. 526-534.

Cunningham, W.L., and Schalk, C.W., comps., 2011, Groundwater technical procedures of the U.S. Geological Survey: U.S. Geological Survey Techniques and Methods, book 1, chap A1, 151 p., accessed February 7, 2017 at http://pubs. usgs.gov/tm/1a1/.

Driscoll, F.G., 1986, Groundwater and wells (2d ed.): St. Paul, Minn., Johnson Filtration Systems, Inc., 1089 p.

Faye, R.E., and Mayer, G.C., 1997, Simulation of groundwater flow in Southeastern Coastal Plain clastic aquifers in Georgia and adjacent parts of Alabama and South Carolina: U.S. Geological Survey Professional Paper 1410-F, 77 p.

Ferris, J.G., Knowles, D.B., Brown, R.H., and Stallman, R.W., 1962, Theory of aquifer tests: U.S. Geological Survey Water-Supply Paper 1536-E, 174 p.

Gordon, D.W., and Gonthier, G.J., 2017, Data collected for Claiborne aquifer study in southwestern Georgia during 2015 to 2016: U.S. Geological Survey data release, accessed February 1, 2017 at https://doi.org/10.5066/F7B8569W.

Halford, Keith, 2009, AnalyzeHOLE—An integrated wellbore flow analysis tool: U.S. Geological Survey Techniques and Methods, book 4, chap. F2, 46 p.
Halford, Keith, Garcia, C.A., Fenelon, Joe, and Mirus, Benjamin, 2012, Advanced methods for modeling waterlevels and estimating drawdowns with SeriesSEE, an Excel add-in: U.S. Geological Survey Techniques and Methods, book 4, chap F4, 29 p., accessed February 7, 2017 at http://pubs.usgs.gov/tm/tm4-F4/.

Halford, Keith, Weight, W.D., and Schreiber, R.P., 2006, Interpretation of transmissivity estimates from single-well pumping aquifer tests: Ground Water, v. 44, no. 3, p. 467-471.

Halford, K.J., and Kuniansky, E.L., 2002, Documentation of spreadsheets for the analysis of aquifer-test and slug-test data: U.S. Geological Survey Open-File Report 2002-0197, $51 \mathrm{p}$.

Hantush, M.S., 1960, Modification of the theory of leaky aquifers: Journal of Geophysical Research, v. 65, no. 11, p. 3713-3725.

Harbaugh, A.W., 2005, MODFLOW-2005: The U.S. Geological Survey modular ground-water model-The Ground-Water Flow Process: U.S. Geological Survey Techniques and Methods, book 6, chap. A16. [Variously paged]

Hicks, D.W., Gill, H.E., and Longsworth, S.A., 1987, Hydrogeology, chemical quality, and availability of ground water in the Upper Floridan aquifer, Albany area, Georgia: U.S. Geological Survey Water-Resources Investigations Report 87-4145, 52 p., accessed February 7, 2017, at http://pubs.usgs.gov/wri/wri87-4145/.

Hicks, D.W., Krause, R.E., and Clarke, J.S., 1981, Geohydrology of the Albany area, Georgia: Georgia Geologic Survey Information Circular 57, $31 \mathrm{p}$.

Hill, M.C., Banta, E.R., Harbaugh, A.W., and Anderman, E.R., 2000, MODFLOW-2000, The U.S. Geological Survey modular ground-water model-User guide to the Observation, Sensitivity, and Parameter-Estimation Processes and three post-processing programs: U.S. Geological Survey Open-File report 2000-0184, 209 p.

Kosugi, Ken'ichirou, Katsura, Sin'ya, Mizuyama, Takahisa, Okunaka, Suemi, and Mizutani, Tasuku, 2008, Anomalous behavior of soil mantle groundwater demonstrates the major effects of bedrock groundwater on surface hydrological process: Water Resources Research, v. 44, W01407, 14 p.

Kruseman, G.P., and de Ridder, N.A., 1990, Analysis and evaluation of pumping test data ( $2 \mathrm{~d}$ ed): Wageningen, The Netherlands, International Institute for Land Reclamation and Improvement, Publication 47, $377 \mathrm{p}$. 
Kuniansky, E.L., and Bellino, J.C., 2012, Tabulated transmissivity and storage properties of the Floridan aquifer system in Florida and parts of Georgia, South Carolina, and Alabama: U.S. Geological Survey Data Series 669, 37 p., accessed February 7, 2017 at http://pubs.usgs.gov/ds/669/.

Langevin, C.D., 2008, Modeling axisymmetric flow and transport: Ground Water, v. 46, no. 4, p. 579-590.

Long, A. F., 1989, Hydrogeology of the Clayton and Claiborne aquifer systems: Georgia Geologic Survey Hydrologic Atlas $19,6 \mathrm{p}$.

McFadden, S.S., and Perriello, P.D., 1983, Hydrogeology of the Clayton and Claiborne aquifers in southwestern Georgia: Georgia Geologic Survey Information Circular IC- $55,59 \mathrm{p}$.

National Weather Service, 2017, National Weather Service Web site: Accessed January 25, 2017, at http://www.weather.gov/.

Papadopulos, I.S., and Cooper, H.H., Jr., 1967, Drawdown in a well of large diameter: Water Resources Research, v. 3, no. 1, p. 241-244.

Piper, A.M., 1944, A graphic procedure in the geochemical interpretation of water analyses: Transactions, American Geophysical Union, v. 25, p. 914-928.

Reilly, T.E., Franke, O.L., and Bennett, G.D., 1984, The principle of superposition and its application in groundwater hydraulics: U.S. Geological Survey Open-File Report 84-0459, 36 p.

Reilly, T.E., and Harbaugh, A.W., 1993, Computer noteSimulation of cylindrical flow to a well using the U.S. Geological Survey modular finite-difference ground-water flow model: Ground Water, v. 31, no. 3, p. 489-494.

Renken, R.A., 1996, Hydrogeology of the Southeastern Coastal Plain aquifer system in Mississippi, Alabama, Georgia, and South Carolina: U.S. Geological Survey Professional Paper 1410-B, 101 p., 42 pls.

Rutledge, A.T., 1991, An axisymmetric finite-difference flow model to simulate drawdown in and around a pumped well: U.S. Geological Survey Water-Resources Investigations Report 90-4098, 33 p.

Stallman, R.W., 1971, Aquifer-test design, observation, and data analysis: U.S. Geological Survey Techniques of WaterResources Investigations, book 3, chap. B1, 26 p.

Theis, C.V., 1935, The relation between the lowering of the piezometric surface and the rate and duration of discharge of a well using groundwater storage: American Geophysical Union Transactions, v. 16, p. 519-524.
Torak, L.J., and McDowell R.J., 1996, Ground-water resources of the lower Apalachicola-Chattahoochee-Flint River Basin in parts of Alabama, Florida, and Georgia - Subarea 4 of the Apalachicola-Chattahoochee-Flint and Alabama-CoosaTallapoosa River Basins: U.S. Geological Survey Open-File Report 95-321, 145 p., 11 pls.

University of Georgia College of Environmental Sciences, n.d., Georgia Automated Environmental Monitoring Network: University of Georgia College of Environmental Sciences Web site, accessed January 25, 2017, at http://www.georgiaweather.net.

U.S. Geological Survey, 2016, National Water Information System-Web interface, accessed January 25, 2017, at http://dx.doi.org/10.5066/F7P55KJN.

U.S. Geological Survey, variously dated, National field manual for the collection of water-quality data: U.S. Geological Survey Techniques of Water-Resources Investigations, book 9, chaps. A1-A10, accessed February 7, 2017 at http://pubs.water.usgs.gov/twri9A.

Walton, W.C., 1962, Selected analytical methods for well and aquifer evaluation: Illinois State Water Survey Bulletin No. 49,81 p.

Williams, L.J., and Dixon, J.F., 2015, Digital surfaces and thicknesses of selected hydrogeologic units of the Floridan aquifer system in Florida and parts of Georgia, Alabama, and South Carolina: U.S. Geological Survey Data Series 926, 24 p., accessed January 25, 2017 at http://dx.doi.org/10.3133/ds926.

Williams, L.J., and Kuniansky, E.L., 2015, Revised hydrogeologic framework of the Floridan aquifer system in Florida and parts of Georgia, Alabama, and South Carolina: U.S. Geological Survey Professional Paper 1807, 140 p., 23 pls., accessed January 25, 2017 at http://dx.doi.org/10.3133/ pp1807. 
Prepared by the USGS Science Publishing Network Lafayette and Reston Publishing Service Centers Edited by Mike Deacon Illustrations by Caryl J. Wipperfurth Layout by Cathy Knutson

For additional information regarding this publication, please contact:

Director, South Atlantic Water Science Center

U.S. Geological Survey

720 Gracern Road

Stephenson Center, Suite 129

Columbia, SC 29210

(803) 750-6100

Or visit the South Atlantic Water Science Center Web site at http://www.usgs.gov/water/ southatlantic/ 



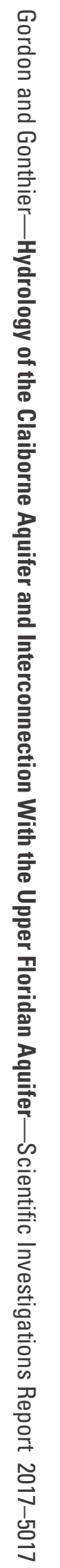

